DEPAR'TMEN'T OF THE IN'IERIOR

UNITED STATES GEOLOGICAL SURVEY

GEORGE OTIS SMITH, DIRECTOR

BULLEIIN 353

\title{
GEOLOGY
}

OF THE

\section{TAYLORSVILLE REGION, CALIFORNIA}

BY

J. S. DILLER

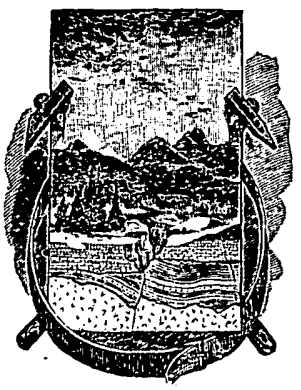

WA SH INGTON

GOVERNMEN'TR INTING OFFICE 1908 



\section{CONTENTS.}

In̉troduction.

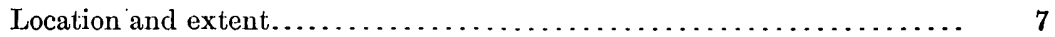

Outline of geography and geology of region.................... 7

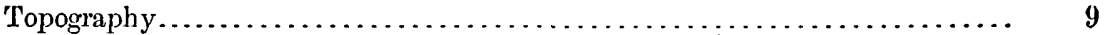

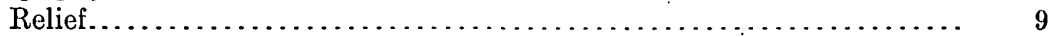

Diamond Mountain block............................ 9

The escarpment.................................. 10

The plateau slope.................................. 10

Valleys on southwest border........................... 10

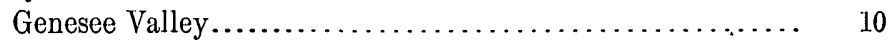

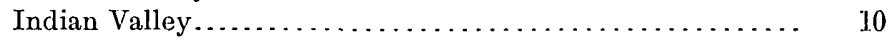

Mountain Meadows.............................. 11

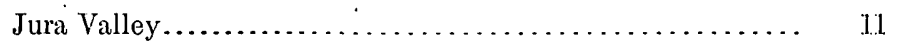

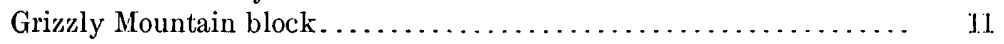

Crest line and escarpment. . . . . . .

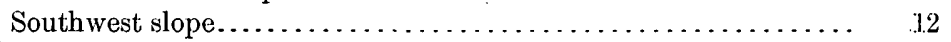

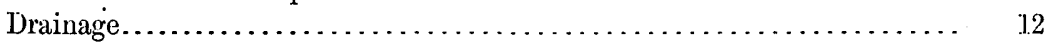

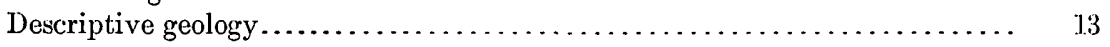

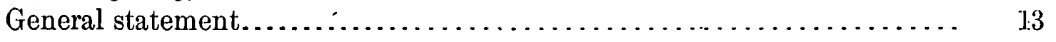

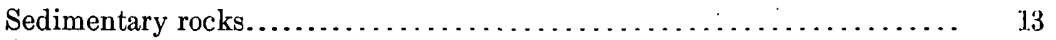

General account..................................... 13

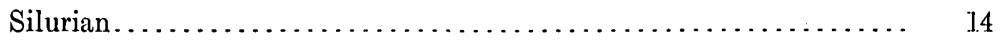

Grizzly formation.............................. 14

Montgomery limestone........................... 16

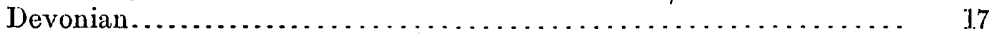

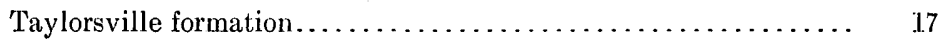

Carboniferous...................................... $\quad 20$

Calaveras group .................................. 20

Arlington formation............................ 20

Shoo Fly formation............................... 23

Peale formation ................................. 24

Robinson formation................................ 26

Triassic............................................ 30

Hosselkus limestone.................................... 30

Swearinger slate.................................... 32

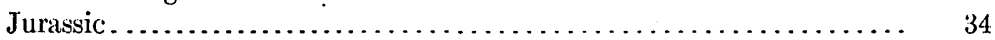

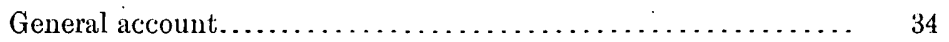

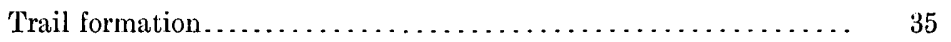

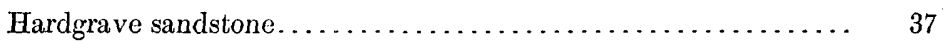

Thompson limestone.................................. 41.

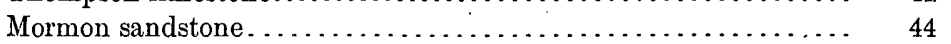

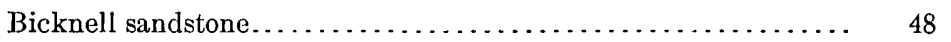

Hinchman sandstone................................. 51

Foreman formation.................................. 53 
Descriptive geology-Continued.

Sedimentary rocks-Continued.

Southern extension of Triassic and Jurassic rocks of the Taylorsville

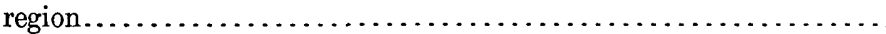

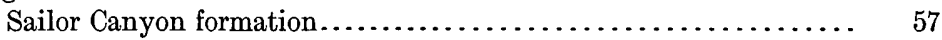

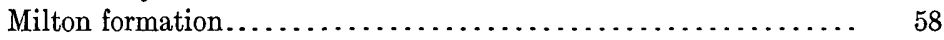

Relation of the Taylorsville Jurassic to the Mariposa............. $\quad 59$

Supposed Mariposa in Nevada............................. $\quad 60$

Tertiary ............................................ 60

Auriferous gravels................................... $\quad 60$

General statement.................................. 60

Jura River channel............................... $\quad 61$

Mount Jura divide............................ 61

Taylor diggings................................. 61

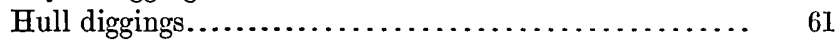

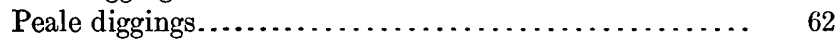

Cascade mine to Mohawk Valley.................... 62

Along Haskell Peak escarpment................... 63

Chips diggings, reversed drainage................ 63

Question as to head of Jura River................. 63

Drainage suggested by rhyolite flow............... 65

Suggestion of double crest .................... $\quad 65$

Fan-shaped drainage of Milton region............... 65

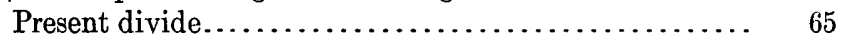

Main mass of auriferous gravel....................... 66

Moonlight region........................... 66

South end of Mountain Meadows.................. 67

North end of Mountain Meadows.................. 67

Willards Creek district.......................... $\quad 68$

Head of Gold Run .......................... 68

Diamond Mountain gravel...................... 69

Diamond Mountain shore terraces.................. 69

Lone Rock and Kettle Rock regions............... $\quad 70$

Isolated masses of gravel northeast of Mohawk Valley........ 71

Classification of the auriferous gravels.................... $\quad 72$

Earlier deposits................................ $\quad 72$

Arkose sands................................... $\quad 72$

Prevolcanic gravels.......................... $\quad 72$

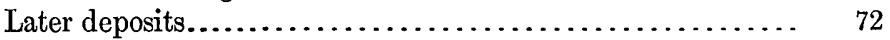

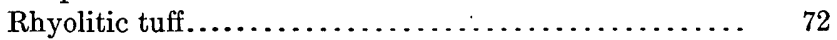

Intervolcanic gravels.......................... $\quad \grave{7}_{2}$

Volcanic flows, chiefly andesitic breccia.............. 74

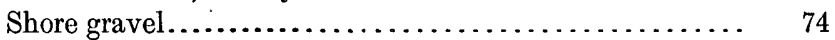

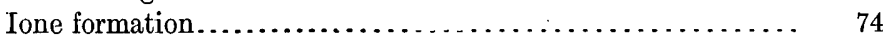

Flora of the prevolcanic gravels....................... 74

Age of the prevolcanic auriferous gravels................. $\quad 76$

General statement............................... $\quad 76$

Eocene flora of southwest Oregon.................... 77

Topography of the auriferous-gravel period................. 78

The two divides................................ 78

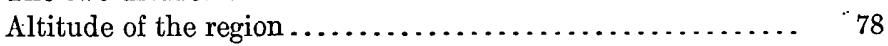

Jura River Valley............................... $\quad 78$

Drainage of Sierra Valley........................... $\quad 78$

Uplift in gravel period............................ 79 
Descriptive geology-Continued.

Sedimentary rocks-Continued. $\quad$ Page.

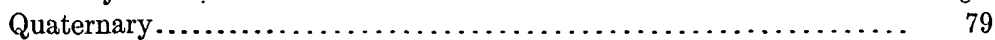

Gravels of Keddie Ridge........................... $\quad 79$

Gravels near Greenville............................ $\quad 79$

North Arm pot-hole.............................. $\quad 79$

Shoo Fly gravel terraces.............................. 80

Glacial moraines................................ 80

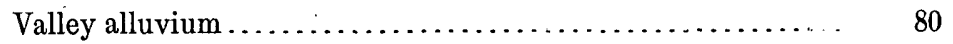

Igneous rocks......................................... 80

General account.................................. 80

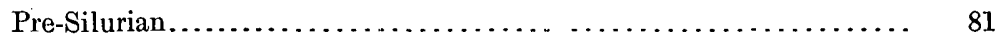

Metarhyolite.................................. 81

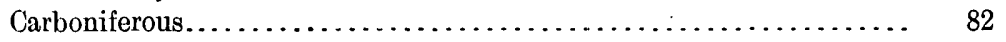

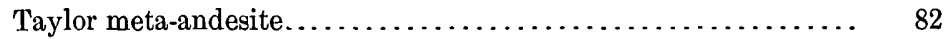

Kettle meta-andesite............................... 84

Reeve meta-andesite............................. $\quad 86$

Jurassic ............................................ 87

Fant meta-andesite................................... 87

Hull meta-andesite............................. 88

Late Jurassic or early Cretaceous...................... 88

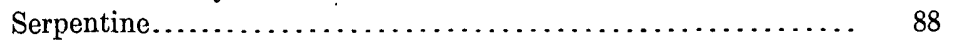

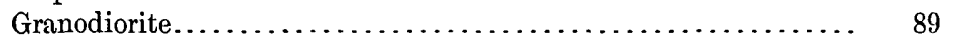

Various dike rocks ................................. 90

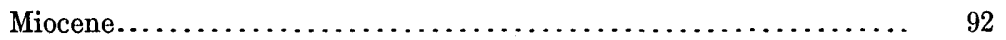

Rhyolite......................................... 92

Pliocene.............................................. 93

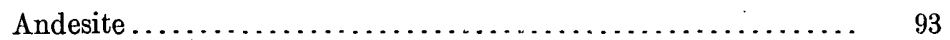

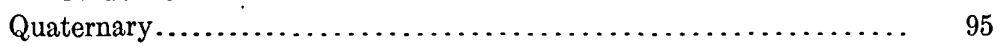

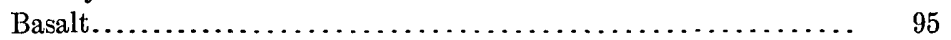

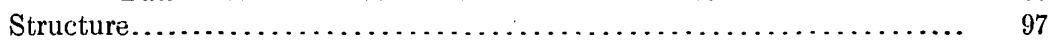

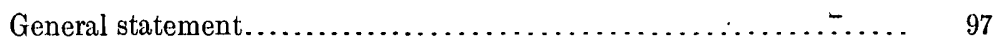

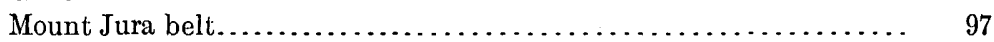

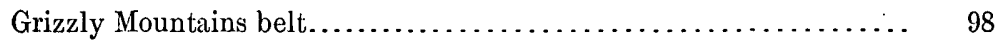

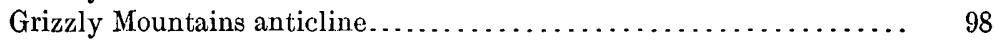

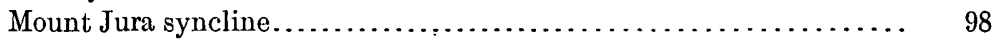

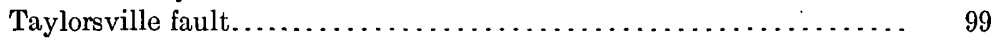

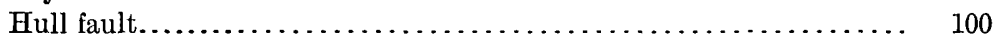

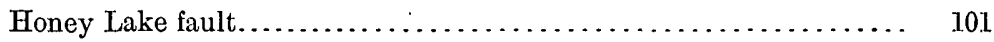

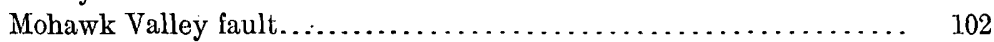

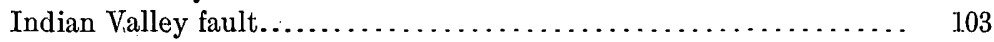

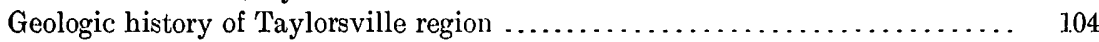

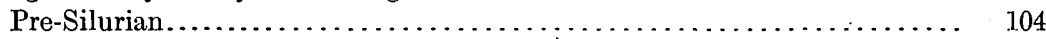

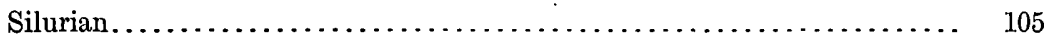

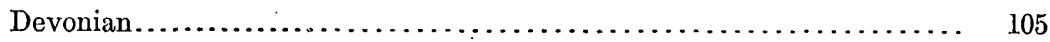

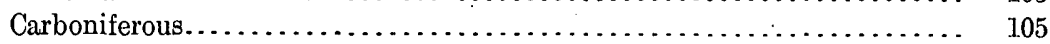

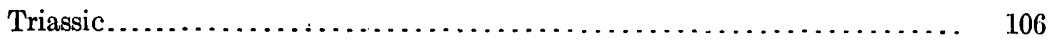

Jurassic ................................................... 107

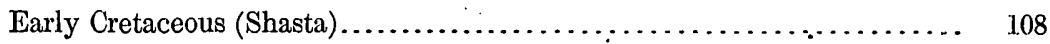

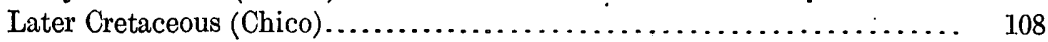

Eocene.................................................... 109

Miocene and Pliocene.................................... 109

Quaternary.......................................... 110 
Economic geology $\ldots \ldots \ldots \ldots \ldots \ldots \ldots \ldots \ldots \ldots \ldots \ldots \ldots \ldots \ldots \ldots \ldots, 111$

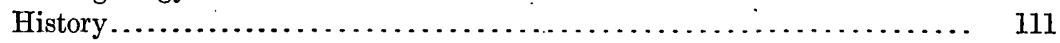

Development in the Crescent Mills belt..................... 114

Development in the Genesee belt.......................... 114

Geology of Crescent Mills belt of mines....................... 114

Geology of Genesee belt of mines.......................... 115

Auriferous gravels............................................ 116

Development........................................ 116

Kinds of gravels......................................... 116

Auriferous gravels of present streams....................... 117

Auriferous gravels of ancient streams ...................... 117

Deposits of iron ore...................................... 118

Deposits of coal........................................ 119

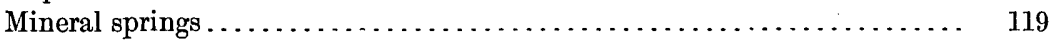

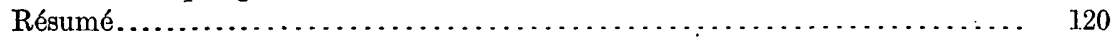

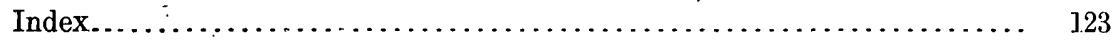

\section{ILLUSTRATIONS.}

Plate I. General geologic map of adjoining portions of the Sierra Nevada, Cascade, and Klamath mountains........................

Page.

II. Topographic and geologic map of south half of Honey Lake quad-

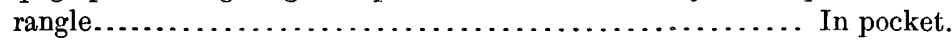

III. Topographic and geologic map of Indian Valley quadrangle.... In pocket.

IV. Columnar section of Taylorsville region..................... 12

V. Surveyed mining claims of Indian Valley region............ 112

Fig. $\quad$ 1. The faults that limit the Sierra Nevada on the northeast............ 8

2. Tunnel section of Grizzly formation, Montgomery limestone, and Taylorsville formation............................. 15

3. Side-fractured pebble in conglomerate of Crystal Lake............ 21

4. Faulted pebble in slaty conglomerate of Crystal Lake............ 22

5. Sections of spurs north of Genesee Valley near Robinson's........ 29

6. Relation of Mormon formation to Hosselkus limestone........... . 48

7. Section of interbedded shale and sandstone of Evans Peak, showing relation of joint and pencil structure...................... 54

8. Plan of pencil structure on plane of stratification................ 54

9. Sketch plan of Diamond Mountain, showing shore terraces on spurs . $\quad 70$

10. Generalized section of spur of Diamond Mountain.............. 70

11. General section of Taylorsville region....................... 96

12. Profile of Jura River bed after deformation................ 110 


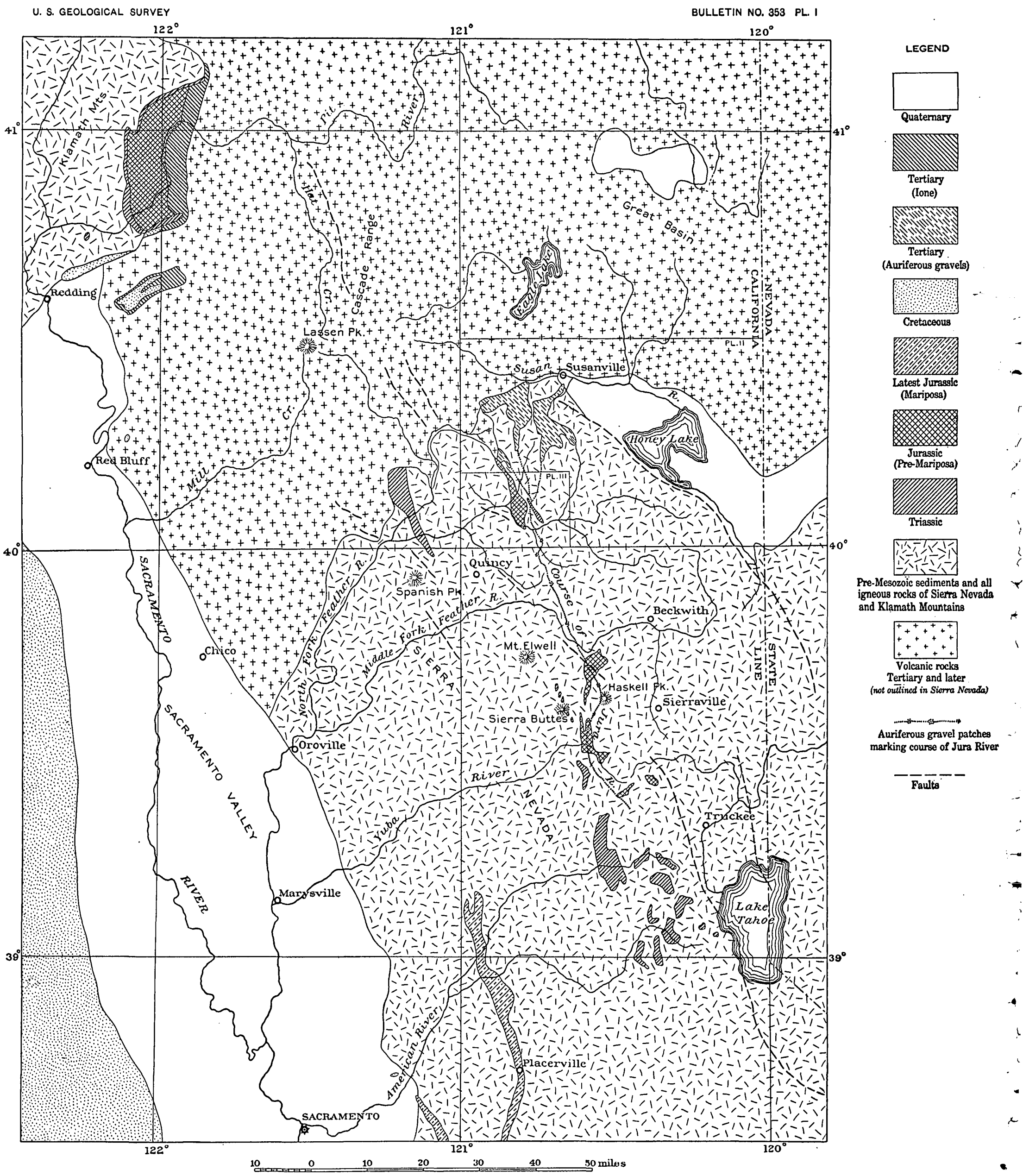

GENERAL GEOLOGIC MAP OF ADJOINING PORTIONS OF THE SIERRA NEVADA AND THE CASCADE AND KLAMATH MOUNTAINS. 


\title{
GEOLOGY OF THE TAYLORSVILLE REGION OF CALIFORNIA.
}

\author{
By J. S. DILLER.
}

\section{INTRODUCTION.}

LOCATION AND EXTENT.

The Taylorsville region is a triangular area on the northern end of the Sierra Nevada in California. It lies in the northeastern angle between the fortieth parallel and the one hundred and twenty-first meridian, and embraces the northeastern part of Plumas County and the adjacent portion of Lassen County, comprising about 750 square miles. The greater portion of the population is in Indian Valley, Genesee Valley, and North Arm. The town of Taylorsville, from which the whole region is here named; is approximately in its center.

OUTLINE OF THE GEOGRAPHY AND GEOLOGY OF THE REGION.

Northern California belongs to five topographic provinces, consisting of three mountain ranges-the Coast, Cascade, and Sierra Nevada-and two valleys-the Sacramento and the valley of the interior, which forms a part of the Great Basin. The Coast Range includes the Klamath Mountains, which occupy the northwest corner of the State. Lassen Peak, the southern end of the Cascade Range, lies between the Klamath Mountains and the Sierra Nevada, as shown in Pl. I, giving them apparent continuity, but in reality separating them, for the Cascade Range is wholly of volcanic origin and presents marked contrast to the Sierra Nevada and Klamath Mountains. The Taylorsville region belongs to the Sierra Nevada, but is bordered on the north by the Lassen Peak portion of the Cascade Range and on the east by the Great Basin.

The main body of the Sierra Nevada has but one crest, with a long, gentle slope southwestward to the Sacramento Valley and a short, steep slope northeastward to the Great Basin. It appears as a great block of the earth's crust tilted toward the southwest. The northern 
end of the range, beyond Lake Tahoe, has three crests, those of Clermont Hill ridge, Grizzly Mountains, and Diamond Mountain, and each crest has a valley at its northeast base. The western crest, the Clermont, is continuous with the main crest of the range north of Lake Tahoe. American and Mohawk valleys lie to the northeast. The other two are crests of blocks that have been added in the Taylorsville region on the northeast of the main block, as shown in fig. 1, causing the eastern face of the range to advance in that direction nearly to Honey Lake.

The geology of the Sierra Nevada is complex. Although the range is the result of an uplift that occurred in comparatively recent geologic time, the material of which it is composed involves a long and

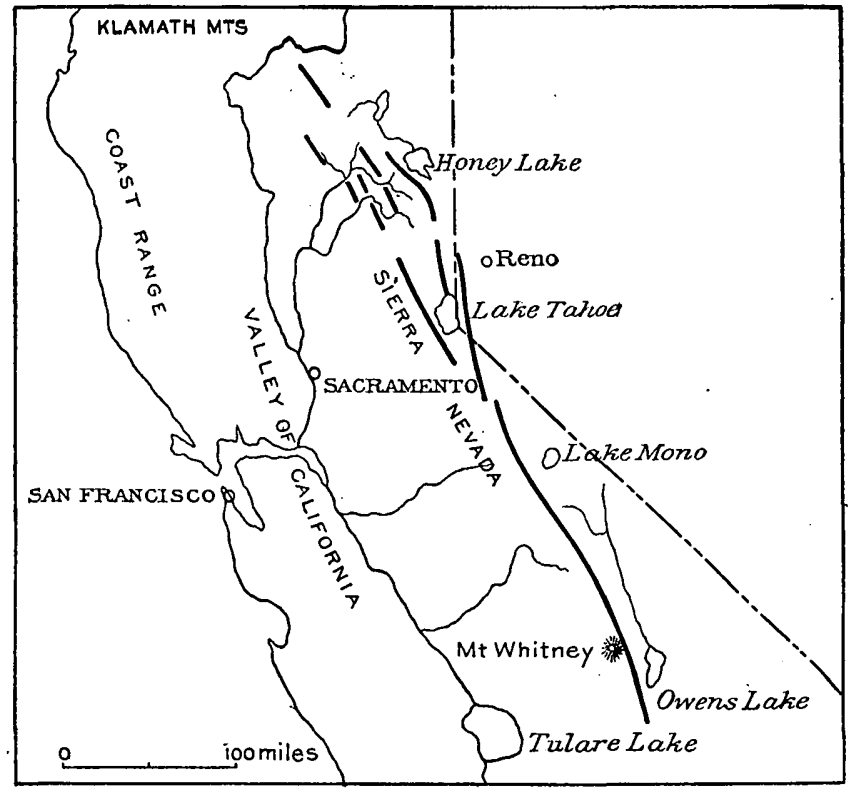

FIG. 1.-Faults limiting the Sierra Nevada on the northeast. Heavy black lines indicate position of faults.

varied succession of deposits of sedimentary and igneous rocks, extending from early Paleozoic to the close of Jurassic time. During that long period the Sierra Nevada region was beneath the sea, receiving sediments from a land area along the eastern border in Nevada. About the close of the Paleozoic era the rocks were compressed and folded, and were intruded to some extent by igneous rocks, so that the Mesozoic sediments, which are of much less bulk than the Paleozoic, were deposited upon the latter unconformably. At the close of the Jurassic the Sierra region was again greatly compressed and uplifted, forming a prominent mountain range. The rocks were folded and rendered schistose or platy in connection with the intrusion of great masses of granitic and other igneous rocks. 
Long-continued erosion during the Cretaceous and Tertiary period, coupled with minor oscillations of the land, reduced the Sierra Nevada to a region of low relief, when streams flowed in broad, shallow valleys, in which the earlier auriferous gravels accumulated. Among the finer gravel beds are fossil leaves, including several varieties of figs, oaks, and other plants, which-indicate that the flora resembled that of a low coastal country like Florida. Near the low crest volcanic vents poured forth streams of lava, which followed the watercourses, covered the auriferous gravels, and displaced the streams. With this volcanic activity and stream displacement came differential uplift, which greatly increased the stream grades and caused them to cut the deep canyons in which they now flow down the western slope of the Sierra, leaving the auriferous gravels of their old beds on the divides far above.

\section{TOPOGRAPHY.}

\section{RELIEF.}

As may be seen on the general map of the Honey Lake and Taylorsville regions (Pl. II), the relief consists of two lines of crests and of two valleys, all having a northwest-southeast trend, parallel to the general course of the Sierra Nevada. On the one hand lies the valley of Honey Lake and Susan Creek, and on the other the belt of valleys stretching from Mountain Meadows to Genesee. Between these lines of valleys lies the Diamond Mountain block, whose crest line is prominent from McKesick Peak to Diamond Mountain. The crests of Grizzly Mountains and Keddie Ridge belong to the Grizzly topographic block, and both blocks lie just northeast of the main crest of the Sierra Nevada at its northern end.

\section{DIAMOND MOUNTAIN BLOCK.}

The Diamond Mountain block, extending from Honey Lake southwestward to Grizzly Mountains, has a width of over 20 miles and a length north of the fortieth parallel of over 50 miles. Its crest line lies close along its northeastern side, from McKesick Peak to Diamond Mountain, presenting a bold escarpment over 2,000 feet high in the short steep slope to Honey Lake. The slope on the opposite side, to the southwest, is long and gentle, having the appearance of a plateau. Beyond Lone Rock the block gradually narrows, loses its relative elevation, and dies out in a plain before reaching the head of Susan Creek. This disappearance, however, is due more to the general rise of the adjoining county toward Lassen Peak, as shown by the drainage lines, than to any decrease in the general elevation of the Diamond Mountain crest, for it maintains its elevation of 7,000 feet near the end. The prominent features of the Diamond Mountain block are the escarpment, the plateau slope, and the valleys along its western border. 
THE ESCARPMENT.

The escarpment although bold is not generally a cliff, and at two points in a distance of 40 miles between Willow Ranch and Gold Run it is traversed by wagon roads. It is remarkably regular with few prominent spurs and reentrants and gives rise to no considerable stream. Gold Run marks its northern terminus. Beyond that point the eastern slope is as long as the western and the divide becomes symmetrical.

THE PIATEAU SLOPE.

The general features of the plateau are best displayed about the heads of Squaw, Last Chance, and Indian creeks, where the general altitude is about 6,000 feet, rising to 7,000 feet at a number of points along the crest. One of the best general views of the plateau is from the slope of Kettle Rock Mountain looking southeast. Although there is a decided community of altitude suggesting an approximation to a common level, it is far from being a complete plain, and yet it may well be called a peneplain. Kettle Rock Mountain is the greatest elevation in it, rising above the general level nearly 2,000 feet, but for the most part by such gentle slopes that the difference of altitude is not out of harmony with the peneplain. The gentle summit slopes continue northwest into Lassen County beyond the limit of the escarpment, where the great difference between the two slopes of the block disappear.

The upper courses of the streams are in broad, shallow valleys, but as they approach the middle portion of the block they cut deeper and deeper until they flow in canyons. Lights Canyon, Cooks Canyon, and the canyons of Indian and Squaw creeks above Flournoy are examples, and they all open into broad alluvial valleys below.

VALLEYS OF THE SOUTHWESTERN BORDER OF THE DIAMOND MOUNTAIN BLOCK.

Genesee Valley.-The general trend of the valley belt along the border of the Diamond Mountain block is northwest and southeast from Genesee Valley to Mountain Meadows. Genesee Valley is at its southeastern extremity. It has a breadth of one-third to threefourths of a mile, and a length of nearly 6 miles northeast and southwest directly across the general trend of the valley belt. It is a flat alluvial plain on both sides of Indian Creek, with irregular border from jutting spurs and lateral branches running up Red Clover, Wards, Hosselkus, and Little Grizzly creeks. None of it is too swampy for use but some is too dry without irrigation. There is a large ranch at each end and four smaller ones between.

Indian Valley.--Indian Valley is much larger than Genèsee, and less regular. The main part extends northwest from Taylorsville to Greenville about 9 miles with an average width of over a mile. At right angles to this is North Arm, which extends up Lights and Cooks 
creeks for nearly 5 miles with a width ranging from a quarter to nearly a mile and widening to the north. Indian Valley proper

* between Taylorsville and Crescent Mills is nearly all arable, but the adjoining portions of North Arm and Greenville Arm, except the borders, are swampy, although the other portions of both arms have large and excellent farms.

A feature of importance in the main body of the valley $2 \frac{1}{2}$ miles northwest of Taylorsville is the Mounds, two dome-shaped hills, which stand out in the valley plain. One rises 100 feet and the other over 200 feet above the surrounding plain. There is a third opposite the entrance of North Arm, a mile north of Taylorsville, but it rises less than 50 feet above the valley plain.

Mountain Meadows.-Mountain Meadows are triangular in shape, widening to the northwest, where they merge into the plains bordering the volcanoes about Lassen Peak. On the southwest they are sharply limited by the steep slopes of Keddie Ridge, but along the eastern side its margin is somewhat less definite on the gentle slope of the Diamond Mcuntain block. The valley is dry to a large extent except in the northwestern part, which is traversed by Fredonia Creek, from the pass of the same name. Mountain Meadows, having a general elevation of 4,800 feet, is about 1,300 feet above the general level of Indian Valley, from which it is separated by a low divide at the head of Cooks Canyon.

Jura Valley.-Between Mountain Meadows and North Arm of Indian Valley there is a broad gap crossing a flat ridge, and the same is true between North Arm and Genesee Valley, where the gap is a broad depression in the ridge crest that joins Mount Jura to Kettle Rock Mountain. These two gaps belong to the plateau or peneplain features of the Diamond Mountain block. A line joining them lies in the axis of the valley belt, and these gaps are remnants of an old valley along that line nearly 2,000 feet above the present valleys of North Arm and Genesee. This old valley lies on the east slope of Mount Jura, hence the name Jura Valley. It was once occupied by Jura River.

\section{GRIZZLY MOUNTAIN BLOCK.}

The Grizzly Mountain block, which lies between the Diamond Mountain block and the main crest of the Sierras and extends from Grizzly Mountains and Keddie.Ridge to American Valley, forms only a small part of the Taylorsville region. The Grizzly Mountain block is smaller and much less regular than the Diamond Mountain block.

CREST LINE AND ESCARPMENT.

The crest line and escarpment are well marked in Grizzly Mountains, which present a steep slope of over 3,000 feet to the west end of Genesee Valley. Toward the northwest the crest line sinks and 
curves, running to Taylorsville, where it disappears in the valley, but rises again in Keddie Ridge and curves back to its northwest course. A small notch is cut by Montgomery Creek across the north end of Grizzly Mountains, but the broad gap in the crest occupied by Indian Valley is more than a mile in width. Keddie Ridge, which carries the crest beyond Indian Valley, is about 14 miles in length and ends in plains at both extremities.

SOUTHWEST SLOPE.

The southwest slope of Grizzly Mountains is larger and gentler than the slope in the opposite direction, but is not so gentle as the corresponding slope of the Diamond Mountain block and retains but few, if any, definite traces of an inclined peneplain. South of the fortieth parallel the crest continues for 15 miles to Grizzly Peak, and a parallel valley follows the western edge of the block all the way from Mohawk to American Valley. About Crescent Mills and Greenville the western slope is broken down to the level of Indian Valley, which crosses the main crest, giving especial prominence to the escarpment of Arlington Heights and Houghs Peak, which form a second crest. Beyond Round Valley Reservoir the slope of the Grizzly Mountain block is better preserved in the northwestern inclination of the divide between Indian Creek and North Fork of Feather River.

DRAINAGE.

The Taylorsville region belongs to two drainage systems, the Great Basin and the Sacramento River, and the water parting is along the eastern crest of the Diamond Mountain block. That which belongs to the Great Basin finds its way into Susan Creek or upper Long Valley, and finally into Honey Lake, which has no outlet, and lies at the very base of the Diamond Mountain escarpment, receiving nearly all its water from the streams flowing southeast or northwest parallel to the escarpment.

All the drainage west of the Diamond Mountain crest goes into the North Fork of Feather River. The drainage from Mountain Meadows passes around the northern end of Keddie Ridge of the Grizzly Mountain block into Big Meadows, where it enters North Fork of Feather River.

The part of the Diamond Mountain block within Plumas County is drained by Indian Creek, whose branches from Cooks Canyon to Last Chance Creek, inclusive, head along the crest forming the county line, while Squaw Creek drains Red Clover Valley, which heads against the great Sierra Valley. The Diamond Mountain and Grizzly blocks, which combine south of the fortieth parallel and merge into the broad summit, Sierra Valley, are completely drained by the tributaries of Feather River. North Fork drains all that part lying north of the fortieth parallel in the Taylorsville region except a small 


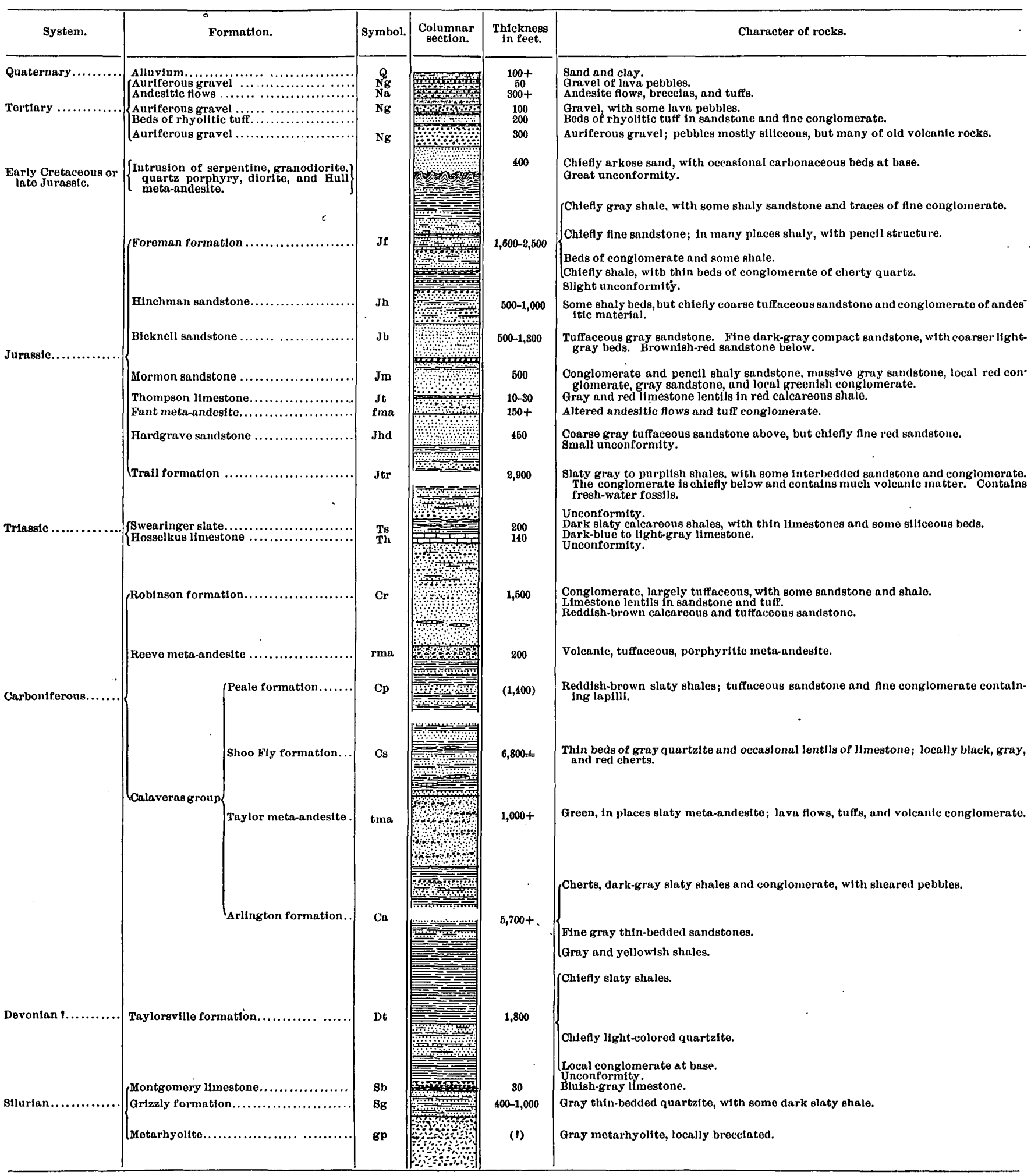


area along the crest 3 miles south of McKesick Peak, which is drained by Sierra Valley into the Middle Fork of Feather River. Both forks of Feather River have cut profound canyons across the crest of the main Sierra block on their way to the Sacramento.

As regards the grades of drainage lines in the Taylorsville region, it should be noted that the headwaters tributary to Indian Creek, being on the peneplain, have exceptionally low grade. From the

- peneplain the streams pass with steep grades through canyons to Indian Valley, upon leaving which Indian Creek again enters a deep, rugged canyon to Feather River.

\section{DESCRIPTIVE GEOLOGY.}

GENERAL STATEMENT.

The results of the areal survey of the Taylorsville region are expressed upon the geologic maps, Pls. II and III, in the discrimination of 18 sedimentary and 12 igneous formations. These contrasted formations are of about equal volume in the district represented by the Indian Valley special sheet (Pl. III), but in the surrounding district upon the north and east, as shown in PI. II, igneous rocks prevail everywhere, though they are locally covered by auriferous gravels or Quaternary lake deposits.

\section{SEDIMENTARY ROCKS.}

\section{GENERAL ACCOUNT.}

The sedimentary rocks of the Taylorsville region contain a more nearly complete record of the geologic history of the Sierra Nevada than has yet been reported in any other portion of the range. The Silurian and Devonian are each represented by 1 formation, but 4 occur in the Carboniferous, 2 in the Triassic, 7 in the Jurassic, 1 in the Tertiary, and 2 in the Quaternary.

The Grizzly formation is the oldest. It is mainly quartzite with some shale, and at the top are occasional lentils of limestone. Its fossils are clearly of Silurian agè. The Devonian slates and quartzites, with local basal conglomerates, have not yet yielded any fossils, but the Carboniferous, represented by the Arlington, Shoo Fly, Peale, and Robinson formations, have fossils at various horizons. These are followed by the Swearinger slate and Hosselkus limestone, whose rich Triassic fauna has long been known. The Jurassic strata, beginning with the Trail formation, continues in succession with the Hardgrave sandstone, Thompson limestone, Mormon sandstone, Bicknell sandstone, Hinchman sandstone, and Foreman formation, most of the horizons being characterized by abundant faunas. The latest Jurassic and Cretaceous are not represented in the Taylorsville region. The auriferous gravels of Tertiary age complete the column to the Quaternary. (See Pl. IV.) 
Lithologic character.-The Grizzly formation is a gray, well-defined but thin-bedded quartzite overlain by lentils of limestone and interstratified with shaly, often siliceous slate (argillite) having irregular cleavage. The beds of quartzite range from 5 to about 20 feet in thickness and run out into shale in a short distance. The shale beds are generally thicker than the quartzite. They are for the most part greenish gray to drab, but sometimes black and more or less flinty, but not much altered. The lighter colored shales are often sandy and constitute the prevailing portion of the formation, although beds of well-marked quartzite are usually present and frequently predominate. The coarser beds of quartzite contain small pebbles of rhyolite, rarely as large as a pea. These beds, with occasional little pebbles, are near the base of the formation and have a thickness of about 200 feet. The black shale, sometimes flinty, is full of traces of organisms, which E. O. Ulrich has identified as sponge spicules. On the eastern slope of Grizzly Mountains, near the northern end, quartzite prevails immediately beneath a lentil of limestone, but north of Montgomery Creek shales occupy the corresponding position, as shown in fig. 2. The section as shown in this figure, however, does not continue below the tunnel, and therefore does not disclose the coarser beds lying at the bottom of the Grizzly quartzite horizon.

Areal distribution and thickness.- The quartzite of the Grizzly formation occupies a narrow belt near the crest and parallel to it on the northeast slope of Grizzly Mountains. It extends from Taylorsville southeast across Montgomery Creek and along the slope, where it is cut into patches by pyroxenite and meta-andesite, reaching the fortieth parallel in the glaciated ravine half a mile northeast of Tower Rock. At this point the belt of Grizzly quartzite abruptly narrows and vanishes along the border of the ancient rhyolite and the overlapping basaltic volcanics. Immediately south of the fortieth parallel this rock has been sought for by $\mathrm{H}$. W. Turner in the Downieville quadrangle, but its presence could not be demonstrated. The length of the belt of Grizzly quartzite from Taylorsville to the fortieth parallel is about 6 miles, and its exposure is not known to extend beyond in either direction. A portion of the area * mapped as Grizzly formation about the mouth of Montgomery Creek, embracing a tract one-fourth of a mile in width and nearly $2 \frac{1}{2}$ miles in length along the left bank of Indian Creek, is referred to this horizon with doubt. Although quartzite and siliceous slates occur there the prevailing rock is thin-bedded sandstone instead of quartzite. Locally the sandstone contains pebbles, but it is generally fine 
grained. At one point it shows decided spheroidal weathering and resembles certain beds in the Arlington formation, from which, however, it differs decidedly in mineral composition. The spheroidal sandstone in question near Montgomery Creek contains quartz grains whose bipyramidal form indicates that they were most likely derived from the underlying metarhyolite.

There are two small outliers of the Grizzly formation near the fortieth parallel a mile northeast of Tower Rock. In both cases they are masses of much crumpled black, flinty slates from 25 to 40 feet in thickness associated with the ancient rhyolite into which they have been folded or faulted.

The thickness of the Grizzly formation, where measured near the northern end of Grizzly Mountains, is about 400 feet, and this is near the maximum. The strike of the formation is northwest and southeast parallel to its outcrop, and its dip is southwest into Grizzly Mountains between Taylorsville slates which lie upon it and a mass of ancient rhyolite on, which it rests.

Relation to adjoining formations.-The contact of the Grizzly formation and the underlying rhyolite is more or less irregular and difficult to follow, but the irregularities are those of the original lava surface accented by much subsequent folding and displacement. This relation may be plainly seen on the lower slope of Grizzly Mountains opposite Huntingtons, where a tongue of

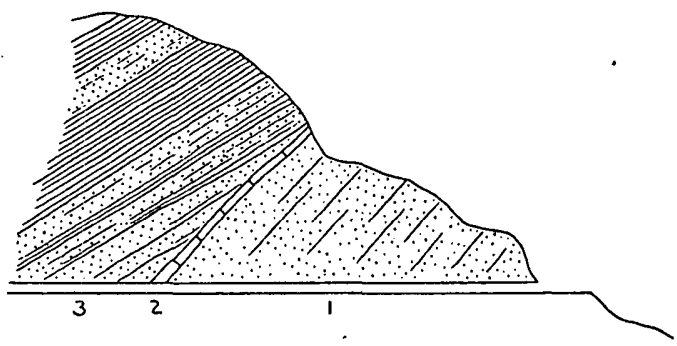

FIG. 2.-Tunnel section of Grizzly formation (1), Montgomery limestone (2), and Taylorsville formation (3). sandstone is folded into the metarhyolite, whose fluidal structure on both sides is parallel to the well-marked bedding in the sandstone. That the rhyolite is older than the overlying quartzite is evidenced by the fact that small pebbles of the rhyolite occur in the quartzite. Although not abundant nor large they are common and characteristic, and confirm the view that the quartzite was deposited on the rhyolite.

Above the quartzite comes the Montgomery limestone, and the two are conformable, as shown in the small section (fig. 2) along the tunnel on the east slope near the crest of the ridge 2 miles south of Taylorsville. The fine conglomerates, sandstones, and slates of the Taylorsville formation overlie the limestone and quartzite apparently with unconformity.

Fossits and age.-The only fossils discovered in the Grizzly formation, outside of the limestone lentils, are sponge spicules found in thin sections of the black shaly portions. They indicate a marine origin 
for the sediments, but afford no definite information as to its age. There can be no reasonable doubt, however, that it is older than the lentils of limestone described below.

\section{MONTGOMERY LIMESTONE.}

Lithologic character.-This limestone was called the Montgomery ${ }^{a}$ limestone from its occurrence on that creek, $2 \frac{1}{3}$ miles south of Taylorsville. The limestone is light to dark bluish gray and cleaves into plates. It has occasional knots or benches of black chert and some of the few fossils are replaced by it. The form of the limestone is lenticular, and the largest lentil has a thickness of 60 feet, with a length of about 200 feet. The strike is approximately parallel to the crest of Grizzly Mountains, and the dip is to the southwest.

Areal distribution.-Five of these limestone lentils have been found at intervals along the western border of the quartzite between Taylorsville and the fortieth parallel. The first occurs at the tunnel shown in fig. 2, where it has a thickness of 20 feet. The second is on the south bank of Montgomery Creek, forming prominent cliffs at an altitude of about 4,000 feet. The third and largest lentil, 60 feet in thickness, is on the crest of Grizzly Mountains, at their northern end, having an altitude of nearly 7,000 feet. This is by far the most important lentil, on account of the fossils it contains. Two miles farther southeast, in the cliff. overlooking the Devils Punch Bowl, is a lentil of limestone about 15 feet in thickness and exposed for 60 feet. No fossils were found here, but the limestone is in the same horizon as that containing the fossils at the northern end of Grizzly Mountains. The last and smallest lens of limestone occurs in the slates near the top of a flat spur one-eighth of a mile north of the fortieth parallel. It is only about 4 inches in diameter. South of the fortieth parallel Turner has not been able to find any exposed lentils of the limestone, nor have any been. found by the writer north of Taylorsville. Limestone has been reported from a well on one of the mounds of Indian Valley, but the determination is a matter of doubt. The extreme limits of the exposed lenses are about 12 miles apart.

Fossils and age.-Fossils were discovered in this limestone on Montgomery Creek and the crest of Grizzly Mountains by Cooper Curtice in 1890. A few fossils were added by others to those collected by Curtice, and among them C. D. Walcott identified the following forms:

Crinoid stems.

Stromatopora sp. (?).

Zaphrentis.

Syringopora (like S. serpens).
Heliolites.

Halysites catenulatus. Orthis (of the type of $\mathrm{O}$. flabellum).

Ormoceras (cf. siphuncles). 
According to Walcott, these fossils are undoubtedly Silurian and "represent the Niagara horizon of the Mississippi Valley and Appalachian provinces."

Last summer the locality was visited and a collection made by James.Storrs. It was referred to E. O. Ulrich, who reports as follows:

The fossils on the whole are in very discouraging condition and in most cases it is impossible to determine them specifically.

1. Halysites catenulatus. The variety that is found, so far as known to me, only in the Silurian above the Clinton.

2. Heliolites cf._interstinctus.

3. Heliolites cf. elegans.

4. ? Favosites. A small ramose species.

5. Cyathophyllum sp. undet. A` small, subcylindrical species.

6. Fragment of a single tube of an undetermined species of Syringopora.

The above fossils are all corals of types indicating an early middle Silurian-in other words, about the age of the Louisville Niagara limestone.

No other exposures of fossiliferous rocks of this horizon are known within hundreds of miles. One of the nearest is in the Eureka region of central Nevada.

Relation to adjacent formations. - In strike and dip the limestone and the underlying quartzite are practically parallel, and their observed contacts indicate conformability. The change in the character of the sediment from siliceous sand and clay to local limestones may have been due to subsidence of the sea floor, but it did not involve deformation sufficiently great to give rise to discordance between the strata. But at about the horizon of the top of the limestone the change in sediments, which become at least locally coarse, appears to be consequent upon deformation of a more pronounced character and will be noted more fully under the Taylorsville formation.

\section{DEVONIAN.}

\section{TAYLORSVILLE FORMATION.}

Lithologic character.-The Taylorsville formation is composed for the most part of fine sediments, chiefly slates ${ }^{a}$. and thin-bedded sandstones, among which there are numerous small layers of fine black chert or occasional less regular masses of red chert, but at the base it is locally a fine conglomerate, and near the middle there are welldefined beds of light-colored quartzite. The conglomerate at the base is greenish gray and its pebbles are indistinct. It is best exposed on the eastern face of the spur above the limestone about a mile south of Taylorsville. The pebbles are small and, in part at least, well rounded. Many of them are of igneous material more or less por-

a The Taylorsville formation was formerly called the Taylorsville slates; Bull. Geol. Soc. America, vol. 3,1892 , p. 372.

50007-Bull. $353-08-2$ 
phyritic. Some are rhyolitic, and in places small fragments of chert are common containing the round spots like those of the siliceous slates in the Grizzly quartzite. Thin sections of the ancient rhyolite show its groundmass very like that of some of the chert. They are easily distinguished in some cases by the presence of quartz phenocrysts on the one hand or round spots of organic origin in the other.

Distribution and thickness.-The Taylorsville formation is best developed a short distance south of Taylorsville, and except where cut by serpentine and pyroxenite it forms a belt southeast along the slope of Grizzly Mountains to the fortieth parallel. Like the Grizzly formation, the exposure of the Taylorsville formation ends near the fortieth parallel. Neither of them has been recognized by Turner in the Downieville quadrangle, which lies immediately south of the fortieth parallel.

Northwest of Taylorsville the outcrop of the Taylorsville formation is interrupted by alluvial deposits of Indian Valley, and it appears beyond only in isolated areas on the end of Keddie Ridge and on the Mounds, and also 2 miles north of Crescent Mills and $1 \frac{1}{2}$ miles west of Greenville. The last is the largest of the isolated areas and contains besides quartzite and shales some distinctly banded black cherts, in which there are no traces of organic remains. West of this area there is a small exposure in the Lassen Peak quadrangle, a few miles east of Prattville on the border of the great lava field. It is probable that some of the isolated areas mapped as Taylorsville formation north and northwest of Indian Valley contain strata which belong to the Grizzly quartzite, but in the absence of the Montgomery limestone they could not be separated.

The known extent of the Taylorsville formation is about 35 miles. For 12 miles northwest of Tower Rock on the fortieth parallel it is associated with the Grizzly formation, but beyond Taylorsville it extends alone with numerous interruptions for about 20 miles to its final cover of lava in the Lassen Peak region. The general dip of the formation throughout its extent, where not disturbed by igneous intrusions, is to the southwest.

The thickness of the Taylorsville formation in the measured section $1 \frac{1}{2}$ miles south of Taylorsville is about 1,800 feet. From this point it appears to thin southward. Near the fortieth parallel only 150 feet are exposed. North of Taylorsville it is so involved with igneous rocks that its thickness has not been determined, but if width of exposure may be taken as an indication the thickness increases in that direction.

Relation to adjacent formations.-The fossiliferous cherty shale pebbles in the conglomerate at the base of the Taylorsville formation appear to have been derived from the black shales of the Grizzly formation and indicate an unconformity of erosion between them, 
although the rocks upon both sides of the contact have essentially the same position. The lack of continuity in the Montgomery limestone suggests that the unconformity is between the limestone and the Taylorsville formation, and while this is probable it could nut be fully confirmed. No pebbles of limestone were found in the conglomerate and the masses of limestone do not appear as irregular remnants left by erosion from a larger mass but are lenticular in shape, as if originally so formed.

Evidence upon this point also may be observed north and northwest of Indian Valley, where the Taylorsville formation appears to lie directly upon the quartz porphyry. The quartzite and limestone of the Grizzly formation were apparently removed by erosion from the surface of the metarhyolite before the deposition of the Taylorsville formation. The local conglomerate, associated with flinty slates and gray sandstones of the Taylorsville formation, was observed in the long, narrow strip running along the western slope of Keddie Ridge parallel to its crest. The pebbles are largely of igneous material, chiefly acid volcanics, presumably derived directly from the adjacent quartz porphyry, which the fragments closely resemble. On the whole, therefore, the evidence seems to indicate a decided unconformity of erosion between the limestone and the Taylorsville formation.

On the upper side-that is, on the southwest-the Taylorsville formation is limited 'by igneous rocks only. Taylor meta-andesite, a basic volcanic rock which spreads from the vicinity of Taylor Rock, overlies the Taylorsville formation on the western slope of Grizzly Mountains, but farther northwest, along Houghs Creek, granite separates it from the Arlington formation.

Age.-The only fossils found in the Taylorsville formation are sponge spicules in the cherty shales, and they are not distinctive. It is certainly younger than the Silurian, which it unconformably overlies. The abundance of the black chert layers is significant on account of the fact that the Devonian strata of the Redding quadrangle of Shasta County, about 100 miles to the northwest, are especially cherty, and in this respect contrasted with the overlying formations of Carboniferous age. In the Taylorsville region the next horizon of sediments above the Taylorsville formation is the Arlington, which is free from chert and is probably of Carboniferous age./ The abundance of Devonian sediments in the Redding quadrangle leads one to expect them at ihis horizon in the Taylorsville rogion, whose general section has many features in common with that of Shasta County, and it is probable therefore that the Taylorsville formation is Devonian in age. 
CARBONIFEROUS.

Calaveras group.

The, Calaveras group was named by Becker, Lindgren, and Turner in their survey of the Gold Belt to include a great body of more or less altered sandstones, shales, and limestones of Carboniferous age. It is widely distributed and occupies a greater area than any other sedimentary formation in the Sierra Nevada. Turner has mapped the Calaveras in the Downieville quadrangle, from which it extends directly across the fortieth parallel into the Taylorsville region.

In order to emphasize the essential unity of this succession of sediments in the Taylorsville region we continue to use the term Calaveras for all those sediments connecting directly with the Calaveras of the Downieville quadrangle. But to bring out the areal distribution and possibly also slight differences in age of the various parts of the Calaveras in the Taylorsville region, it is subdivided, largely as heretofore, ${ }^{a}$ into the Arlington formation, the Shoo Fly formation, and the Peale formation, which will be considered separately before the latest Carboniferous, the Robinson formation, is taken up.

ARLINGTON FORMATION.

Lithologic character.-The Arlington formation is made up chiefly of fine, gray, thin-bedded sandstone, with some shale in part silicified and a few beds of conglomerate. It may be considered as having three members. In the lower member yellowish shales prevail, grading upward into shaly and thin-bedded greenish-gray sandstone, of which a great mass constituting the middle member is exceptionally well exposed in the bold escarpment of Arlington Heights. There is a narrow belt of yellowish-gray sandstone in the upper portion of the middle member that is somewhat coarser than the rest and is characterized by well-developed spheroidal weathering. It is composed of angular grains of fresh plagioclase, with a smaller amount of augite, green hornblende, and magnetite. Quartz, if present at all, is not common. This peculiar sandstone bears considerable resemblance to certain tuffaceous beds found in the Bragdon formation of the Redding quadrangle of California, but in the present case no definite volcanic material could be recognized either in the field or under the microscope to prove its volcanic origin.

In the upper member slaty gray shales are most abundant, with local conglomerates and highly silicified red jaspery portions near the top. The slaty shales are well exposed about Crystal Lake, where they occasionally split into thin slabs several feet in diameter. In the summit of Houghs Peak the silicification is extreme, and the mass is converted into red and gray chert veined with white quartz associated with small veins of magnetite and staining of hematite. 
In the cliffs along the western border of Crystal Lake are beds of conglomerate interstratified with the slaty shale in which a few fossils have been found. Most of the pebbles are of gray chert, but a few are of red chert and sandstone, and locally there are a considerable number of pebbles of a holocrystalline, hypautomorphic granular igneous rock composed largely of feldspar with less chlorite and small amounts of magnetite and quartz. The chlorite probably represents original augite. The feldspar is sometimes (as in 6696) untwinned. When twinned (as in 6699) they appear to be Carlsbad showing only two bands. Rarely smaller bands appear, but evident polysynthetic twinning is certainly not present. The pebbles of igneous material are well rounded, waterworn, and very largely of the type noted above, which for the present may be called quartz-augite diorite.

The interbedded slates and conglomerates strike $\mathrm{N}$. $36^{\circ} \mathrm{W}$. and dip $54^{\circ} \mathrm{SW}$., and the well-marked slaty cleavage is parallel to the stratification. The conglomerate is not coarse. Its largest pebbles are rarely over 4 inches through, but they have all suffered decided deformation, which reached a maximum in the plane of cleavage. The rock is cut by two systems of joints; one runs N. $40^{\circ}$ E. and dips $69^{\circ}$ SE., while the other strikes N. $36^{\circ}$ W. and dips $45^{\circ} \mathrm{NE}$.

Joints of both systems cut directly through the pebbles. On the first system the peb-

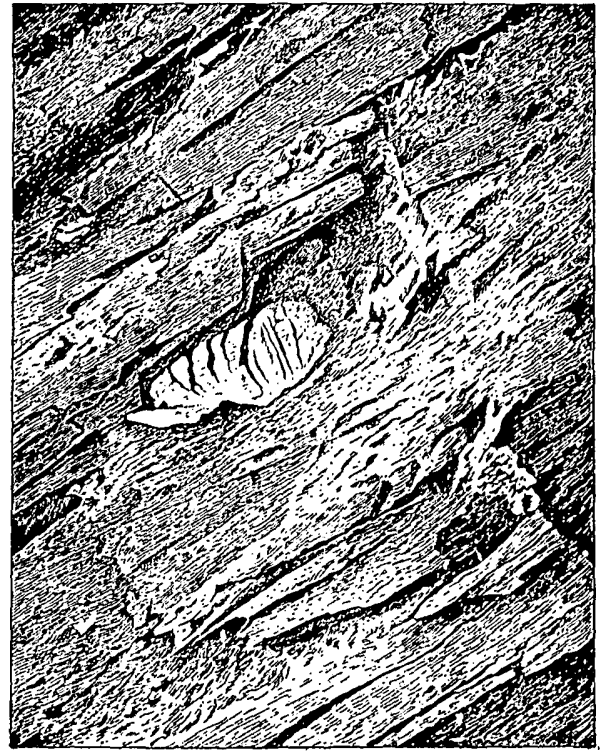

Fig. 3.-Side-fractured pebble in conglomerate of Crystal Lake.

bles have been greatly elongated; on the second system the same pebbles are but slightly drawn out, and the greatest deformation in both cases lies in the plane of cleavage. Some pebbles are embedded in the slates and there often fractured, as shown in fig. 3 from a photograph illustrating pebbles exposed on a joint of the northeastsouthwest system. The degrees of fracturing range from incipient cracks on the upper side only to complete fissuring and faulting, as illustrated in fig. 4 , as if the upper part of the pebbles was in a plane of greater motion than the lower, resulting in the upper-side fracturing of many pebbles and the faulting of a few having the imbricated faulted parts inclined in the same direction as the slaty cleavage. 
Distribution and thickness.-The Arlington formation has its greatest development between the summits of Houghs Peak and Houghs Creek. From this point it extends northwest into the Lassen Peak quadrangle and has been briefly described in the folio of that quadrangle. To the southeast it extends with diminishing width of outcrop to a short distance beyond the fortieth parallel into the Downieville quadrangle, where it is entirely cut off by the volcanic mass of meta-andesite ("augite porphyrite") from the vicinity of Taylor Rock. The total length of the outcrop is about 30 miles. The stratification is clearly marked with strike northwest and southeast and dip to the southwest, and with a regularity that indicates conformability throughout the entire succession of strata having a measured thickness of 5,700 feet.

Relation to adjoining formations.- The Arlington formation on the surface is completely surrounded by igneous rocks. About the southeast end and on the south and southwest the formation is limited by a great volcanic mass of meta-andesite. On the northeast it is limited by metarhyolite and serpentine

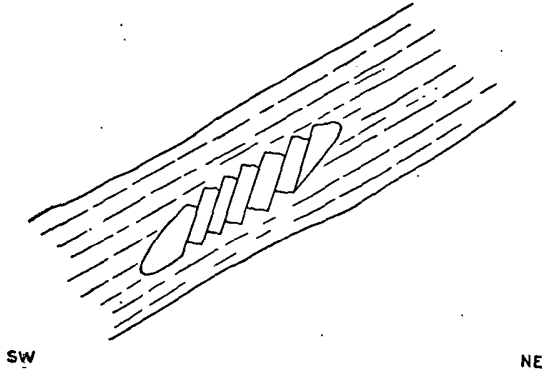

FIG. 4.-Faulted pebble in slaty snnglomerate of Crystal Lake. in the Greenville region; but along Houghs Creek it is bounded by granodiorite. All of these bordering igneous rocks except the metarhyolite are younger than the Arlington formation and penetrate or overflow it. They separate the Arlington beds on the one hand from the Taylorsville formation and on the other from the Shoo Fly

beds of the Calaveras. In general position the Arlington formation is parallel to both of these formations and lies between them.

Fossils and age.-The only fossils found in this formation were discovered by James Storrs on the border of Crystal Lake. Girty reports from this locality "crinoid stems, coral?, Stenopora? sp.," and remarks that it "is probably Paleozoic, but possibly not Carboniferous." It is younger than the Taylorsville and older than the Shoo Fly portion of the Calaveras. One is probably Devonian and the other apparently Carboniferous, so that the probable age of the Arlington is either late Devonian or early Carboniferous. In the Redding region there is a great thickness of early Carboniferous sediments in the Baird and also in the Bragdon, which is poor in fossils below and in some respects, as already pointed out, like the Arlington. It is possible that the Arlington and Bragdon represent approximately the same horizon of Carboniferous below the great limestones of that system. 
SHOO FLY FORMATION.

Lithologic character.- The Shoo Fly formation ${ }^{a}$ was named from a locality on the stage road between Crescent Mills and Quincy, near the bridge crossing Indian Creek, where the beds are well exposed. They consist mainly of clay slates above and quartzite below. The clay slates are light to dark gray, generally dull, but sometimes silky and in places slightly micaceous. They contain occasional films of gray or black flinty material, as well as thin beds of sandstone and fine conglomerate of quartz pebbles, leaving no doubt as to the sedimentary origin of the formation, and yet one finds traces here and there of beds composed exclusively of volcanic fragments, some of which are clearly vesicular. Near the middle portion are lentils of limestone, some of which attain a thickness of over 50 feet and form conspicuous ledges on the spur half a mile east of Clear Creek Bridge.

The quartzites which prevail in the upper portion of the formation are thin bedded, somewhat slaty, and indistinctly schistose with micaceous partings. On a fresh fracture the quartz grains are bluish, but the rock weathers reddish. Veins of white quartz are common and locally abundant throughout the formation, and in general it may be said that the Shoo Fly beds are more affected by regional metamorphism than any other strata in the Taylorsville region.

Areal distribution and thickness.-The Shoo Fly formation occupies the southwest corner of the Taylorsville region and is well exposed on the road between Shoo Fly Bridge and Spanish Creek. This is part of the large area to the west and south around American Valley as illustrated by the areal map in the Downieville folio by Turner.

The development of cleavage in the Shoo Fly formation has obscured its stratification and rendered the determination of its thickness more difficult. A measured section makes it 6,800 feet thick, but this is probably too high.

Relation to adjacent formations.-The Shoo Fly formation is everywhere separated from the Arlington by a wide belt of meta-andesite of volcanic origin, indicating that the epochs during which the two sets of beds were deposited were separated by an interval of contemporaneous volcanic activity. The general dip of both sets of strata is to the northwest, and there can scarcely be any doubt that the Shoo Fly formation overlies the Arlington and is of later deposition.

Age.-Traces of crinoids were the only fossils found in the Shoo Fly formation of the Taylorsville region, but a few miles to the southwest, near Spanish Ranch, occur characteristic Carboniferous fossils, such as Fusulina, leaving no doubt as to the age of that portion of the Calaveras group.

a Bull. Geol. Soc. America, vol. 3, 1892, pp. 272-275. In the Lassen Peak folio they were included in the Calaveras. 
Lithologic character.-In lithologic character the Peale formation is decidedly variable. Reddish to brown slaty shale, sometimes gray or greenish, passing into tuffaceous sandstone and fine conglomerate, is most common. The fine conglomerate contains much volcanic material, with occasional red lapilli and small lenses of calcareous matter. Thin beds of gray quartzite occur also, and masses of black, gray; or red chert form prominent ledges.

The tuffaceous beds are well exposed and fossiliferous on the horse trail from Wards Creek to Peale diggings, also beyond Hosselkus and to within about a mile of the Lucky S road. The chert is best exposed near the forks of the road just east of Hosselkus, where there is a prominent ledge of red banded chert full of quartz veins, but no considerable amount of hematite with it as on Houghs Peak. Red siliceous slate and chert occur near the summit along the trail from Wards Creek to Peale diggings, as well as in the divide at the head of Hinchman Ravine, but the locality for most conspicuous banding, like that of the Marquette iron-ore region of Michigan, is a mile northwest of Evans Peak and still farther in the same direction near Keddie Lake. At the last two localities, which lie beyond the limits of the Indian Valley Special sheet, the Peale beds have not been separated from the Robinson formation.

Areal distribution and thickness. - The Peale formation makes a narrow interrupted belt extending from Little Grizzly Creek north across the fortieth parallel at Peale diggings, on the divide between Wards Creek and Little Grizzly Creek, then somewhat more westerly across Genesee Valley at Hosselkus to the divide 2 miles northeast of Mount Jura, where it is covered up by the overlapping Foreman formation before reaching the Lucky S road. Small masses of these beds, chiefly red chert, adjoin the gravel of the Taylor diggings and form much of the hill at the head of Hinchman Ravine. In Keddie Ridge, northwest of Evans Peak, masses of chert occur, and they probably belong to the horizon of the Peale formation, but were not separated from the Robinson, which occurs in the same region. The thickness of the Peale formation, measured 2 miles east of the summit of Mount Jura, is about 1,400 feet.

Fossils and age.-Fossils were discovered in the Peale formation by T. W. Stanton along the trail to the Peale diggings at an elevation from 4,500 to 5,000 feet. Several collections were made by others at the same place in 1893 , and all the collections were examined by Charles Schuchert, who reports the following:

Orthis michelini.

Streptorhynchus crenistria?

Ambocœlia planiconvexa.

Spirifer striatus.
Productus? sp.

Pelecypod like Yoldia or Leda.

Phillipsia sp.

Lophophyllum profundum. 
In 1904 Storrs and I collected a number of fossils near the same place. They were examined by G. H. Girty, who reports (January $12,1905)$ the following forms:

Fusulina sp.

Crinoid fragments.

Fistulipora sp.

Meekopora sp.

Stenopora? sp.

Girty states (May 18, 1905):

I have also examined the collection upon which Mr. Schuchert reported. The fauna is well shown by Mr. Schuchert's list, and I regret to say seems to possess little in common with the fossils from the same area reported on January 12, 1905, which I examined, and also with those from the Robinson beds. In fact, if this fauna be brought into comparison with those of the McCloud River section, it is more nearly related to the Baird fauna than to those of the McCloud limestone or Nosoni formation. At the same time I am not prepared to definitely correlate the material examined by Mr. Schuchert with the Baird, as many of the characteristic Baird species are wanting.

There seems to be no doubt that the Peale formation is Carboniferous, and most likely older than the Robinson-formation, to be noted presently. In the Downieville folio the Peale formation, which extends south of the fortieth parallel, was included by W. H. Turner in the Calaveras formation, and in the Genesee Valley region there is not sufficient reason for their separation.

The chert near Hosselkus is minutely spotted as if radiolarian. In thin section the microscope reveals the fact that the chert contains many spots with sufficient structure to enable Ulrich to determine their radiolarian origin. No trace of sponge spicules, such as are so common in the cherts of the Grizzly and Taylorsville formations, was found.

Relation to adjacent formations.-The Peale formation is almost completely surrounded by igneous rocks, meta-andesites, and is in part made up of pyroclastic material of the same sort. It is evident, therefore, that it represents approximately an epoch of volcanic activity, although the rock by which it is immediately enveloped may be in large part intrusive. This appears, at least, to be the case of the mass which splits the belt of the Peale formation into two parts southeast of Genesee.

The Peale formation dips to the southwest and overlies the metaandesite which separates it from the Robinson formation on the northeast, but, as will be explained in considering the Robinson formation, the rocks have been overturned. Farther northwest, in the head of South Fork of Foremans Ravine, the outcrops of jaspery and associated rocks cease, and the Peale formation appears to run under the Foreman formation, by which it is unconformably overlapped. No fossils were found in that vicinity and the contact was not definitely traced. 


\section{ROBINSON FORMATION.}

Lithologic character.- The Robinson formation includes a succession of variable sediments ranging from shale to conglomerate and composed chiefly of igneous material with occasional lentils of limestone. The most characteristic portion is a gray sandstone which weathers reddish brown. It contains more or less disseminated carbonates of lime forming small lentils up to 15 feet in thickness. Microscopic examination shows that the sand of which it is composed is largely of volcanic material, and includes traces of crinoids, with occasional bryozoa in many cases, even when they can not be seen with the unaided eye. Below the calcareous horizon the reddish-brown thinbedded tuffaceous sandstone and shale extend to the bottom of the formation. Above that horizon the pyroclastic material becomes somewhat coarser and passes into a tuffaceous conglomerate containing fossiliferous limestone nodules and beds of reddish-brown sandstone, here and there with crinoid stems like that of the principal horizon below. Crystals of feldspar are common and sometimes prominent in this tuffaceous rock, giving it the general aspect of a solid lava flow, and there is good reason for surprise on finding in it distinct impressions of gasteropods, spirifers, corals, and crinoids.

Areal distribution and thickness.-The Robinson formation forms a subdivided and greatly interrupted belt, extending from 4 miles south of the fortieth parallel on Little Grizzly Creek northwest, across Genesee Valley and the Lúcky S mine road divide, and disappears before reaching North Arm of Indian Valley. Beyond Evans Peak it reappears, extending along the slope of Keddie Ridge, as shown in Pl. V, to its northern end, beyond Dyer Peak, where it sinks beneath the lavas of Lassen Peak. The width of the belt is from one-half to $1 \frac{1}{2}$ miles, and the total length is nearly 30 miles.

The belt is divided longitudinally by volcanic rocks into two subordinate belts, which cross Genesee Valley at the ranch known as Robinson's, from which the formation is named. On the north side of Genesee Valley the rocks of this formation make up the mound east of the Robinson house and the point crossed by the road west of the house. At the last locality the brown calcareous sandstones and tuffs are full of fossils. The outcrop passes between the two ledges of the Hosselkus limestone and follows the western border of that limestone northwest beyond Hosselkus Creek: It is cut off by meta-andesite along the summit of the divide, but reappears and shortly ends on the north side in a ravine leading down to Peters Creek. Several miles farther northeast on Peters Creek, running up from the trail at an altitude of about 4,500 feet, there is a small mass of characteristic reddish and gray tuffaceous sandstone enveloped by igneous rocks. The characteristic little fossils it contains leave no doubt as to iț identity. Similar sandstones were found at other 
points along Peters Creek, but thin sections revealed no microscopic fossils. Isolated outcrops of Robinson beds occur also near the fortieth parallel among the tributaries of Wards Creek.

The thickness of the Robinson formation measured a short distance north of Genesee Valley is 1,150 feet. At that point the structure is complex and the exposure not complete, but the total thickness can not be much greater.

Fossils and age.-The first fossils collected from the Robinson formation were probably obtained by Ashburner, Brewer, and King in 1861, but sufficient characteristic fossils to determine the horizon were not obtained until 1890, when Cooper Curtice visited the region and discovered many new localities of Mesozoic and Paleozoic fossils. Since then a large number of fossils have been collected at various points from the Robinson formation, chiefly from the reddish-brown sandstone and tuff on the first spur, about half a mile northwest of the Robinson house.

December 8, 1891, C. D. Walcott reported the following fossils from the Robinson locality:

Campophyllum ? sp.

Favosites sp.

Crinoids.

Archæocidaris.

Fenestella 2 sp. undet.

Streptorhynchus crenistria.

Productus semireticulatus.

Productus punctatus?

Spirifer lineatus?

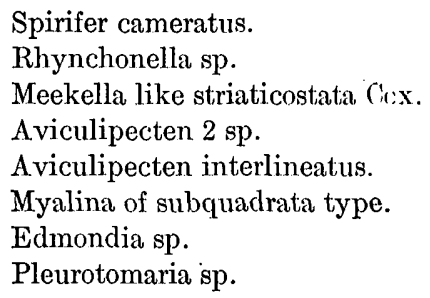

From essentially the same locality Storrs, in 1904, collected fossils numbered 6885 and 6886 , among which Girty identified:

Calcareous algxe?

Fusulina elongata Shum.

Lophophyllum n. sp.

Squamularia near S. guadalupensis.

Dielasma? sp.

Actinostroma?? sp.

Stromatopora ?? sp.

Half a mile northwest of the Robinson locality, on the west of the ridge, at an altitude of 4,700 feet, in approximately the same beds, more fossils were collected (No. 6749), among which Girty (January 12, 1905) recognized:

Calcareous algæe?

Fusulina sp.

Rugose coral ?

Archæocidaris sp.

Rhombopora, lepidodendroides group.

Spirifer sp.

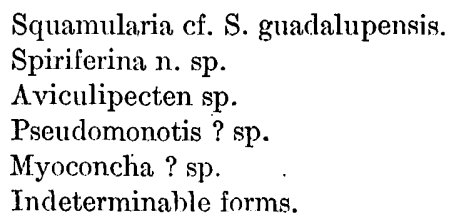

In the collections from the conglomerate (6732-6734) between the two localities noted above Girty found:

Aulopora sp.

Striatopora n. sp.

Cystodictya sp.

Rhombopora, type of lepidodendroides.

Lophophyllum? sp.

Streptorhynchoid brachiopod? 
Some of the fossiliferous limestone nodules in the conglomerate looked like pebbles, but their occurrence in fine beds interstratified with the conglomerate shows that the calcareous nodules are indigenous and not derived. The above lists, as far as I am aware, contain the only fossils thus far determined from the type locality of the Robinson formation on the north side of Genesee Valley.

South of Genesee Valley, near the Five Bear mine on the west side of Wards Creek, G. H. Goodhue found in the Robinson belt some imperfect fossils among which Girty recognizes the "dorsal valve of a brachiopod belonging to the genus Meekella, though possibly it might be a Geyerella." This locality is just west of the mill of the Five Bear mine, and the material looks promising for the collector.

Four miles south of the fortieth parallel, on Little Grizzly Creek, at the southern end of the Robinson belt as mapped by H. W. Turner in the Downieville folio, a number of fossils were collected at various times by Curtice and Stanton. Girty has recently examined the collections and reported the following forms:

\section{Crinoid stems.}

Archæocidaris sp.

Crania sp.

Schizophoria sp.

Orthotetes ? sp.

Meekella sp.

Chonetes n. sp.

Productus semireticulatus?

Marginifera n. sp.
Spirifer aff. S. cameratus.
Spirifer sp.
Spiriferina aff. S. pulchra.
Squamularia lineata?
Pugnax ? sp.
Rhynchonella sp.
Myalina sp.

Marginifera n. sp.

Spirifer aff. S. cameratus.

Spirifer sp.

Spiriferina aff. S. pulchra.

Squamularia lineata?

Pugnax ? sp.

Myalina sp.

Since the Robinson formation was named ${ }^{a}$ the extensive development of the Carboniferous in the McCloud River region of California has been studied and subdivided into Nosoni, McCloud, Baird, and Bragdon. The Genesee and McCloud localities are over 100 miles apart, and from a paleontoiogical point of view Girty has given the following statement concerning their correlations:

The fauna of the Robinson beds is varied and interesting, although always preserved so as to make its siudy a difficult matter. Comparing it with the three wellcharacterized faunas of the McCloud River section, those of the Baird, McCloud, and Nosoni formations, one readily discovers a rather close correspondence to the Nosoni fauna, while nothing resembling the faunas of the Baird and McCloud formations has yet been found in the Robinson beds. As many species are common to the two formations, the evidence at hand certainly favors correlating the Robinson with the Nosoni.

The fauna from Little Grizzly Creek, while showing certain differences from the typical Robinson, probably belongs to the same horizon. It is at least not the fama of the Baird or Mccloud.

In the foregoing lists of Girty "calcareous algæ" refers to a very minute, almost microscopic, fossil first discovered in the Carboniferous limestone of the Klamath Mountains. ${ }^{b}$ They occur abundantly in 
portions of the Robinson beds and were referred to David White for examination. His report, dated December, 1905, is as follows:

After examining excellent sections of the peculiar little fossils in the limestone from California, I am disposed to legard them as foraminiferal and having nothing whatever to do with plants. The organisms seem to be composed of successively enlarged chambers in linear arrangement, although the two or three earlier chambers occasionally show a relative position suggesting spirality. The central area of each chamber wall is somewhat irregularly perforated after the manner of various foraminiferal genera. These perforations are irregular in form and appear to have thickened margins with a greater or less amount of columnar development. The external surfaces of the chamber walls do not seem under ordinary magnification to exhibit either the perforations or the structure which are to be expected in coralline algæ.

While possessing no systematic knowledge of the Foraminifera, I venture the opinion - that the species is distinct from, though probably related to, Loftusia columbiana, though at the same time I should question its reference to the genus Loftusia.

The only closely related fossil reported elsewhere in the Carboniferous of the Sierra Nevada is noted by Turner in the Bidwell Bar

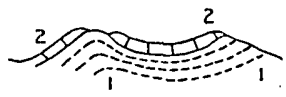

(A)

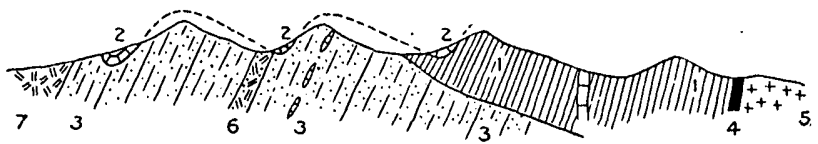

(B)

$1 / 4$

FIG. 5.-Sections of spurs north of Genesee Valley near Robinson's. 1, Swearinger slate; 2, Hosselkus limestone; 3, Robinson formation; 4, contact zone (hornfels); 5 , granodiorite; 6 , Reeve meta-andesite and tuff; 7, Taylor meta-andesite.

folio, page 3, from Edmanton, about 10 miles southwest of Quincy. The original specimens on which Schuchert's determination was based are not available for comparison, but it is not improbable that they are identical with those of Genesee Valley and Klamath Mountains and that the Robinson formation occurs at Edmanton.

Relation to adjacent formations.-The older rocks to which the Robinson formation is related are the Taylor meta-andesite and the Peale formation upon the southwest, while the newer beds, the Hosselkus limestone, Swearinger slate, and Trail formation, lie upon the northeast. First as to the older formations. As stated in connection with the Peale formation, they are separated from the Robinson formation by a belt of Taylor meta-andesite. It is a volcanic rock with pronounced porphyritic structure. In some places the most prominent phenocrysts are plagioclase; at others they are augite. The tuffaceous conglomerate and sandstone of the 
Robinson formation are composed almost wholly of volcanic material erupted in connection with the effusion of the mass of meta-andesite. They dip to the southwest beneath the sheet of volcanics which was the source of their material. That they have been overturned is demonstrated not only by this inverted succession but also by the fact that both the meta-andesite and the Robinson formation dip southwest beneath the Peale beds, which, as the fossils show, are of still greater age.

The relation of the Robinson formation to the newer strata, the Hosselkus limestone and Swearinger slate, which lie mainly upon the northeastern border, is shown in fig. $5, A$ and $B$, which illustrates a section running across the points of limestone a mile and a half northeast of Genesee. In that locality the Robinson beds evidently lie unconformably beneath all the later formations with which they come into contact.

TRIASSIC.

HOSSELKUS LIMFSTONE.

Lithologic character.- The Hosselkus limestone is dark blue on fresh fracture, but weathers light gray, and contains a few veins of white calcite. It is thin bedded and in some places decidedly slaty, forming prominent ledges on the divide between Genesee Valley and Hosselkus Creek, a mile northeast of the Hosselkus ranch, from which the limestone was named. It is well characterized by small ammonites. Although they are not only uncommon but indistinct, yet they readily serve as a means of distinguishing this limestone from any other. In the Redding region, where this limestone is particularly well developed, the upper part is lighter colored and more massive, with a spirifer-like shell, and the lower part thinner bedded and darker, with small coiled forms, but in the Taylorsville region no such differences are apparent:

Distribution and thickness.-The most important outcrops of this limestone are on the divide already indicated north of the Robinson place. It forms two hills on the crest, running nearly northeast for half a mile, then turns northwest and crosses the valley of Hosselkus Creek, but soon disappears. This continuous exposure is only about 2 miles in length, but an isolated outcrop occurs at each end along the strike, one at the head of a ravine tributary to Peters Creek and the other near the road a mile east of Hosselkus, increasing the total length of exposure to about 6 miles but not extending it beyond North Arm to the northwest or Genesee Valley to the southeast.

Several isolated outcrops of the Hosselkus limestone occur on the lower slope of Grizzly Mountains, a mile southwest of the mouth of Little Grizzly Creek. They convain irregular patches of cherty matter and traces of crinoid stems, both round and pentagonal. These 
outcrops are approximately in line and make an exposure nearly a mile in length. The general strike is N. $5^{\circ} \mathrm{E}$., and the dip $70^{\circ} \mathrm{NW}$. into Grizzly Mountains. Over 50 feet of limestone are exposed. Traces of red beds occur at its base, though it is for the most part directly in contact with the meta-andesite. Just above the limestone black flinty material occurs which suggests some of the Swearinger slate, and judging from the size and character of the limestone, as well as its fossils and association, there appears to be little doubt that this mass really belongs to the Hosselkus limestone.

Notwithstanding its restricted occurrence in the Taylorsville region, it is more widely distributed to the northwest in the Lassen Peak quadrangle, where it is included with other sediments in the Cedar formation. In the Redding quadrangle, where it has its greatest development, it is rich in fossils and remarkable for its lenticular character. The greatest thickness of the Hosselkus limestone in the Taylorsville region is about 140 feet.

Fossils and age.-The fossils collected from this limestone by Professor Hyatt and others in the Taylorsville region have not yet been fully worked up. A partial list is given by Hyatt: ${ }^{a}$

I. Arcestes-phylum of $A$. tornati.

Arcestes-phylum of $A$. galeati.

Arcestes-phylum of $A$. bicarinati.

Arcestes-phylum of $A$. sublabiati.

Badiolites, allied to B. eryx Mojsis.

Juvavites, allied to $J$. erlichi Mojsis.

Tropites, may be young of species occurring in Halobia slates.

Atractites.

Arcestes (I) is very abundant, but whether the other forms are abundant or not it is difficult to say at present. The materials gathered show that the rock is full of fossils, but these can not be obtained in any reasonable time by means of surface work. Besides the species mentioned, there is a form of Acrochordiceras, with finer - costæ than those occurring in the Muschelkalk, a possible Balatonites, like B. waageni of the Noric, and some other fragments of ceratitinæ, all indicating a fauna rich in ammonoids, which will some day yield a good harvest to patient, work.

Professor Hyatt concludes that the age of the Hosselkus limestone as indicated by the fossils is upper Triassic. To this list Spiriferina and fish vertebra, as determined by Stanton, were added last summer. This limestone has not yet been thoroughly examined for reptilian remains, such as J. C. Merriam has found in the Redding quadrangle, but as the limestone of the Taylorsville region is more altered and much less fossiliferous, reptilian remains are less likely to occur. In the Redding region the more massive upper portion of the Hosselkus limestone is characterized by the presence of Spiriferina, while the lower, darker, thin-bedded portion often abounds in small ammonites. In the Taylorsville region an attempt was made to determine the upper and lower sides of the limestone by its fossils 
Spiriferina was found at only one point on the side adjoining the Swearinger slate. In this respect it agrees with the Redding region, and tends, as we shall show later, to confirm the view that the Hosselkus limestone on the crest of the divide north of Genesee Valley is overturned. It should be noted, however, that the small coiled forms of Arcestes are most abundant on the same side, which does not strengthen the view concerning the Spiriferina.

Relation to the Robinson formation.-The reference of the Hosselkus limestone to the upper Triassic and the Robinson formation to the upper Carboniferous indicates a decided gap between them, a gap which is at least partially filled in the more complete section of the Redding region, where a great thickness (over 1,000 feet) of andesitic and rhyolitic lavas, with 1,500 feet of overlying shales, sandstones, and tuffs of Triassic age, comes between the horizon of the Robinson formation and that of the Hosselkus limestone. It is evident, therefore, that in the Taylorsville region there is a decided interruption between the Hosselkus limestone and the Robinson formation. It is possible, however, that their contact in the Taylorsville region is a plane of displacement, and that the formations of the Redding region missing in the Taylorsville region may, in part at least, be thus accounted for. This matter will be considered more in detail in the discussion of the relation of the Swearinger slate to adjacent formations. (See fig. 5.)

\section{SWEARINGER SLATE.}

Lithologic character.- The Swearinger formation is composed chiefly of dark slaty shale, sometimes becoming more or less calcareous and at others decidedly siliceous, but the thin beds of limestone or chert form only a small proportion of the whole mass, In the side of the Swearinger slate adjoining the Hosselkus limestone thin lenticular beds of limestone become more abundant. They are generally dark," with irregular cherty or sandy layers, and fossiliferous.

Distribution.-The Swearinger slate has a very limited distribution in the Taylorsville region. Its best exposure is on the spur which we called "Triassic spur," running up from Swearinger's house and spring to the point of Hosselkus limestone near the crest where the area divides. A small part keeps southwest of the limestone and crosses over to the spur, which is chiefly of Robinson beds. On this spur, which has been called the "Carboniferous spur," near the limestone is the locality of Hyatt's "Halobia bed," while the Monotis bed, Daoneila bed, and Rhabdoceras bed of Hyatt are on the "Triassic spur."

The main body of the Swearinger slate extends north along the eastern or northeastern side of the Hosselkus limestone for about $2 \frac{1}{2}$ miles from Genesee Valley, gradually narrowing to the northwest and finally disappearing. It could not be found along Hosselkus Creek, 
where the Trail formation comes into contact with the Hosselkus limestone, nor south of Genesee Valley, where the Trail formation comes in contact with the Robinson. ${ }^{-T}$ The outcrop of the Swearinger slate in the Taylorsville region is limited along the strike to a distance of less than 3 miles and a width where greatest of about a third of a mile. Along the eastern border it is much altered in contact with the granodiorite of the region.

Thickness.-The greatest thickness of the Swearinger slate exposed along Genesee Valley, where measured, is about 200 feet, but the amount cut off by the granodiorite or covered by the overlapping Trail formation we have no means of estimating except by comparison with formations of the same horizon in other regions; such comparison indicates that the thickness is probably not over 400 feet.

Fossils and age.-The fossils of the Swearinger slate were discovered and described by the Geological Survey of California under Prof. J. D. Whitney. Our knowledge of the fauna was greatly extended by Prof. Alpheus Hyatt, who has published ${ }^{a}$ lists of the forms found in the subordinate paleontological horizons within the formation. They need not be repeated here except to note that the form from these beds once regarded as Monotis subcircularis is now considered by J. P. Smith and others to be Pseudomonotis. Professor Hyatt regarded the Swearinger slate as belonging to the upper Triassic, equivalent to the upper Noric of the Alpine Triassic, and as far as I am aware this reference has not been changed essentially by the somewhat later researches of Professor Smith.

Relation to adjacent formations.-The general dip of the Swearinger slate is to the southwest beneath the Hosselkus limestone, and on this account it was at first supposed ${ }^{b}$. to be older than the Hosselkus limestone. In the Redding quadrangle of Shasta.County, where these Triassic rocks are extensively exposed and much less disturbed, Prof. J. P. Smith discovered that the Pseudomonotis horizon, corresponding to at least part of the Swearinger slate, is above instead of below the Hosselkus limestone. ${ }^{c}$ A study of the same region as set forth in the Redding folio confirms us in the same opinion, and shows that in the Taylorsville region the Triassic has been overturned, reversing the natural order of superposition. Everywhere the Swearinger slate and the Hosselkus limestone are essentially conformable. In the Taylorsville region they do not appear coextensive, but this lack may be due to displacement.

The only other sedimentary formation with which the Swearinger slate comes in contact is the Robinson, and judging from their faunal relations, belonging, respectively, the one to the top of the Triassic

a Bull Geol. Soc. America, vol. 3, 1892, pp. 397-400.

$b$ Idem, pp. 272 and 395.

$c$ Jour. Geology, vol. 6, 1898, p. 778.

50007-Bull. $353-08-3$ 
and the other near the top of the Carboniferous, they must be in unconformable contact, and the discordance must represent a time interval of long duration, an interval which is represented in the Redding region, as already explained, by a great thickness of lavas overlain by 1,500 feet, chiefly of shales - the Pit formation, belonging to the middle Triassic. The conformity of the Swearinger slate and the Hosselkus limestone and the unconformity of both on the Robinson formation is shown in fig. $5, A$ and $B$, which illustrates a section near Robinson's place.

Beginning with the limestone on the left-hand spur, where it has been burned for lime, we find it contains fossils that identify it with the Hosselkus limestone of the next two spurs to the east. This spur is made up chiefly of slates in which no fossils have been found. The first ravine toward the right is cut in meta-andesite, the eastern side of which is tuffaceous and belongs to the Robinson formation, The tuff and calcareous sandstone both contain an abundance of Carboniferous fossils, and in connection with the tuffaceous conglomerate which underlies the sandstone they form the second spur of the section, fig. 5, $A$, up to an elevation of 4,500 feet. Above that point, as shown in fig. $5, B$, the spur is composed of Halobial beds of the Swearinger slate overlain by the Hosselkus limestone, and both are fossiliferous. They form an arch over the spur to both ravines, down which they extend far enough to appear in fig. $5, A$. The strike of the Robinson formation on the lower part of the spur carries them unconformably beneath the Triassic arch, and it is evident that the line of contact between Paleozoic and Mesozoic is one of displacement, along which the overturned Triassic was shoved eastward across the truncated edges of the Robinson formation. The local disappearance of the Swearinger slate between the Hosselkus limestone and the Robinson formation is most likely due to displacement.

JURASSIC.

GENERAL ACCOUNT.

There are seven Jurassic formations of the Taylorsville region. The Trail formation is the oldest; then follow the Hardgrave sandstone, Thompson limestone, Mormon sandstone, Bicknell sandstone, Hinchman tuff, and Foreman formation in regular succession. With the exception of the last their surface distribution is limited to a comparatively small area about Mount Jura, and to facilitate matters it may be stated here that the whole set of beds have been overturned and that the Hardgrave sandstone apparently lies on top. In their attitude they are like the Triassic and Carboniferous, already described. The strike is northwest and the dip southwest. 
TRAIL FORMATION.

Lithologic character.-The Trail formation includes a mass of strata composed largely of slaty shales with some interbedded sandstones and conglomerates. It is well exposed along Hosselkus Creek on the trail, hence the name. The shales are often purplish or red, but perhaps more frequently gray, with pencil structure locally developed, and contain in places numerous cherty nodules of carbonate of lime. Well-marked slaty structure is not uncommon. The sandstones are generally fine, often somewhat slaty, are thin bedded, and vary from gray to almost black. The conglomerates of slate and sandstone pebbles, sometimes 3 inches in diameter, generally contain much volcanic material. Approaching the contact with the granodiorite in many places the fine sediments become darker and more compact, with conchoidal fracture, and pass into regular hornfels, a specimen of which from Hornfels Point is No. 134 in the Educational Series of Rocks. ${ }^{a}$. Some of the beds of tuff are well defined, ranging from 10 to 50 feet or more in thickness, and occasionally coarse. Tuffaceous conglomerates are most abundant on the side toward the Swearinger slate, but extend throughout the formation, and a strip of 50 feet of slaty conglomerate occurs in the volcanics which bound the sediments on the northeast.

Distribution.-There are two principal areas of the Trail formation, one north of Genesee Valley and the other south. That north of Genesee Valley is blunt wedge-shaped, with its base 2 miles in width along Hornfels Point, where the sediments have been greatly altered by the underlying granodiorite. This area borders the Swearinger slate and Hosselkus limestone, crosses Hosselkus Creek, but is cut off by the volcanics before reaching the Lucky $\mathrm{S}$ road. From near its southeast corner it sends off two irregular projections. The long, narrow strip running northwest across Hornfels Point to Hosselkus Creek is chiefly slaty, sometimes pebbly shale. The bedding dips $83^{\circ} \mathrm{SW}$. and strikes N. $50^{\circ} \mathrm{W}$., parallel to the course of the belt, which is in places only 60 feet in width, and is bounded on both sides by volcanic rocks related to metaaugite andesite. The projection running east lies between the granodiorite and the volcanics. Much of it is greatly altered by the underlying granodiorite, and, consisting largely of volcanic material, may perhaps belong with the volcanics on the north rather than to the Trail formation.

From Genesee Valley the Trail formation extends southeast to the basalt flows of Ingalls Peak. It lies between the granodiorite on the one hand and andesite porphyry on the other, except for a short distance northeast of Genesee mine, where it comes in contact with the slates of the Robinson formation. The total length of the exposure of the Trail formation along the strike is about 7 miles and is limited in both directions by volcanics. 
Thickness.-The thickness of the Trail formation was measured on the prominent spur next north of Hornfels Point descending into the sharp bend of Hosselkus Creek and found to be about 2,900 feet.

Fossils.-Fossils have been carefully sought for in the Trail formation, but with little success. However, traces of plants and animals have been found together at an elevation of 5,600 feet on the next spur north of Hornfels Point, and also a half mile northeast of the Gruss mine at an elevation of 4,700 feet south of Genesee Valley. Nothing whatever could be made of the plants, but of the other fossils Stanton reports "undetermined small bivalves, possibly Estheria, a crustacean. It is a nonmarine genus occurring in fresh or brackish water and is a common form in the Trail beds. Similar fossils occur in the Carboniferous as well as in Triassic and later formations." It is evident therefore that the fossils furnish little aid in determining the taxonomic position of the Trail formation. For this we must depend chiefly upon its apparent relation to the Swearinger formation.

Relation to Swearinger formation.-The general dip of the Trail formation on the measured section is southwest at an angle ranging from $35^{\circ}$ to $80^{\circ}$, and it passes directly beneath the Swearinger slate and Hosselkus limestone. Attention has already been called to the fact, well illustrated in the Redding region, that the Swearinger slate is younger than the Hosselkus limestone and that in the Taylorsville region it has been overturned. This overturning includes also the Trail formation, and indicates that the Trail formation is the one next newer than the Swearinger. It seems evident also, from the way in which the Trail formation overlaps first the Swearinger slate and then the Hosselkus limestone to the Robinson formation, that the Trail formation is unconformable on all of them. The only other rocks, besides those just mentioned, that come in contact with the Trail formation are granodiorite and the various volcanics by which the Trail formation has been covered and its exposures limited.

Correlation.-The horizon of the Trail formation, as far as it can be made out in the Taylorsville region, appears to be unconformably over the Swearinger slate, in essentially the same relative position as the Modin formation of the Redding quadrangle at the base of the Jurassic sediments. Lithologically the two formations are similar and may be regarded as approximately equivalent, but this correlation secures no direct support from the paleontologic evidence. The Modin formation is locally rich in fossils and they occur in many places, although there are many other places where none could be found. Stanton compared the two faunas and reports that "Estheria has not been found in the Modin formation, but its absence from that formation is to be expected because all the fossils known from it are marine. The fossils present no serious objections to regarding the Modin and Trail beds as time equivalents." 
The relation of the Trail formation to the Hardgrave sandstone, which in the Taylorsville region is its successor, will be considered with the later formation.

\section{HARDGRAVE SANDSTONE.}

Lithologic character.-The Hardgrave sandstone is red or gray in color. It varies from fine shaly sandstone to conglomerate and is almost wholly of a tuffaceous character. The most common color is red, ranging from brick red to dull brown, but much of it is gray, and the two colors are intermingled irregularly in the same bed. The bedding is generally well marked, but in a few localities the massive outcrops show little trace of stratification. Where the sediments are fine the sandstone passes into shale, which occasionally shows a decided slaty cleavage and breaks up into long, slender, pencil-shaped fragments. Generally the sandstone is so fine as not to appear granular and breaks with a splintery fracture. The rock is firmly lithified and yet is comparatively soft, owing to the weakness of the calcareous cement. When the coarser forms of Hardgrave sandstone are broken the fracture generally passes around the grains instead of through them, allowing them to stand in relief upon the fracture surface and make it rough. Rarely it is hard and flinty, much fractured, and veined. In acid both the red and gray varieties effervesce freely, and locally they contain small limy patches. Carbonate of lime is the principal cement, but in the red and weathered forms oxide of iron plays an important part. Near its contact with igneous rocks it is colored yellowish green by epidote. Coarse gray sandstone and fine conglomerate are much less abundant than the finer forms. They afford a much better opportunity to see the volcanic character of the material. It is mainly volcanic sand, made up of crystal fragments of plagioclase feldspar with many lapilli, usually more or less vesicular, and often filled with minute lath-shaped crystals of feldspar, which are for the most part so altered that their polysynthetic twinning, if present, can not be seen. Many of the feldspar fragments are plagioclase, but a somewhat smaller number appear to be orthoclase and possibly some quartz. One of the striking features of this sandstone, apparent only on microscopic examination, is the paucity of quartz.

Distribution.-The Hardgrave sandstone is limited in its distribution within the Taylorsville region almost exclusively to the slope of - Mount Jura, and occurs in two belts. One, the main belt, lies along the western base of Mount Jura, and the other, the crest belt, lies near the crest of the prominent spur running south from the summit of Mount Jura.

The main belt, wavy in its course, runs southeast almost continuously along the western base of Mount Jura from North Arm, near 
Dead Fall Lane, to Huntington's, and beyond to the lower slope of Grizzly Mountains, where two small areas mark its termination against a great mass of ancient quartz porphyry. The total length of this belt is a little over 4 miles, with a width ranging from a few feet to a third of a mile. This belt is the most accessible, and, lying on steeper slopes, contains better exposures than most of the other areas. Coarse gray calcareous sandstone, weathering very rough, crops out at a number of points along the western border, and east of it the finer red and gray beds occur. They are well exposed by the road a short distance northeast of Taylorsville, opposite the steel bridge, and about a mile farther southeast, near Donnerwirth's, but outcrops occur throughout the greater portion of the belt, though somewhat less abundant and conspicuous than those of the meta-andesite next eastward. The strike of the beds everywhere is approximately parallel to the course of the outcrops, and the dip is westerly. The interruptions in this belt east of Taylorsville, opposite the mouth of Montgomery Creek and on the lower slope of Grizzly Mountains, are due chiefly to the eruption of the meta-andesite.

The next most important area is the one which parallels the first in the crest belt. It is a narrow belt extending a little east of south from the summit of Mount Jura along the crest overlooking Hinchman Ravine. In lithology and fossils it is in the main identical with the belt just noted, but near the summit is somewhat more crushed and veined.

Between these two belts on the western slope of Mount Jura there are five smaller masses, three of which lie directly southwest of the Jura summit, one farther south, and another, the largest of the separated masses, lies a little farther north. A more isolated small area lies at an elevation of 4,500 feet on the northern end of Mount Jura, near the old lime road.

There is only one other area to mention, and that is one of the smallest and most isolated. It is about three-fourths of a mile. northeast of the stage road at the crossing of Hinchman Ravine, and was discovered by the indefatigable Curtice. Lying outside of the area marked out by the two belts on Mount Jura, its degree of isolation is very much greater than that of any of the other areas in the region. The identification of all these isolated masses rests on paleontologic as well as lithologic evidence, and the attitude of the strata with westerly dip is essentially the same in all the areas.

The extremely limited and patchy distribution of the Hardgrave sandstone within a few square miles about Mount Jura is a striking feature. It does not occur anywhere else in the Sierra Nevada, but 80 miles to the northwest it has an extensive development along the border of the Klamath Mountains in connection with the Potem formation. The interval is now covered largely by the lavas of Lassen 
Peak, but during the Jurassic the two areas must have been directly connected.

Thickness. - The maximum thickness of Hardgrave sandstone as measured half a mile north of Donnerwirth's may be 850 feet, but is possibly much less, for the measurement involves a large taluscovered slope in which the limit of the sandstone could not be definitely determined. At a number of points in the same belt 250 feet of red and gray beds are well exposed. In the crest belt running south from the summit of Mount Jura two measurements were made. One-third of a mile from the summit the Hardgrave sandstone is 112 feet in thickness, and three-fourths of a mile from the summit, near the crest at the head of a prominent spur descending southeast to the mouth of Hinchman Ravine, it is 124 feet in thickness; the upper 54 feet are gray sandstone partly coarse, while the lower 70 feet are red. It is evident that in the main belt the sandstone is much thicker than in the crest belt. It decreases in thickness and runs out against older formations to the south, but northward it may continue its thickness beneath newer formations.

Age.-The paleontologic investigations of the Hardgrave sandstone were made by the late Prof. Alpheus Hyatt, whose preliminary report is as follows: ${ }^{a}$

The Hardgrave sandstone contains the remains of a very abundant fauna and the fossils are sufficiently well preserved.

The most abundant species are the following: Pecten acutiplicatus, Meek, is to be expected wherever this sandstone occurs, and can be called its characteristic fossil in this region; Entolium meeki is perhaps the next in abundance and is almost as widespread in distribution; Pinna expansa is not found everywhere, but it forms banks like Ostræa or Unio in some places and is often found associated with the two above named.

The age of the Hardgrave has been determined by cumulative evidence. That it was probably a member of the Lias, as previously stated by Prof. Jules Marcou, became evident after a preliminary examination of the fossils, but the facts leading to the conclusion that it is more likely a member of the upper Lias than of the lowest Lias were more difficult of acquisition. It contains many fossils having affinities with those of the lowest or infra Lias, and the Modiola and Mytilus might even have occurred in the uppermost Trias or Rhætic. On the other hand, some forms have very close relations to the same genera as they appear in the Mormon sandstone, or Oolite, of the same locality. Pinna, Gervillia, Ctenostreon, Entolium, Trigonia, and Cidaris show an assemblage of upper Lias types. The species of Entolium and Ctenostreon are closely related to those of the Oolite above, and one species of Trigonia resembles the young of a species from the Oolite of western Europe. The most conclusive evidence, however, is furnished by the single well-preserved specimen of Glyphea, which I was so fortunate as to find in the typical locality close to the village of Taylorsville, and the Goniomya, allied to G. v-scripta, Agassiz.

The 42 species exhibited, which were selected from the collections of the Geological Survey, do not represent the entire fauna. I have still further restricted the list given below to those species which are either characteristic or have been described and figured or can be closely compared with representative European species.

a Bull. Geol. Soc. America, vol. 3, 1892, p. 401. 
Europe.

Montlivaultia, n. sp. (?) ............... Maimei, Chap. et Dewal.; lower Lias. Ostræa, sp . ........................ Ostræa irregularis, Chap. et Dewal.; inferior Lias to middle Lias.

Ostræa, n. sp .................... Ostræa arietis, Quenst.; lower Lias.

Anomia, n. sp......................Anomia striatula, Terq. et Piette; lower Lias.

Modiola, n. sp ....................Modiola psilonoti, Quenst.; lower Lias.

Mytilus, n. sp......................Mytilus psilonoti, Quenst.; lower Lias.

Mytilus, n. sp......................Mytilus terquemianus, Chap. et Dewal.; lower Lias.

Pinna expansa, n. sp.................Pinna hartmanni, Auct.; lower Lias.

Gervillia linearis, n. sp . ...............Gervillia lanceolata, Quenst.; upper Lias.

Gervillia gigantea, n. sp..............Gervillia aviculoides, Quenst.; Oolite.

Gervillia gigantea, n. sp . ..............Gervillia betacalcis, Quenst.; middle Lias.

Lima, n. sp........................ Lima nodulosa, Terq. et Piette; lower Lias.

Lima, n. sp........................ Lima charta, Dum.; lower Lias.

Lima, n. sp........................ Lima galathea, Dum.; upper Lias.

Ctenostreon, n. sp ................... Lima tuberculata, Dum.; lower Lias.

Pecten acutiplicatus, Meek..............

Lima sinuata, Meek................... Lima acuticostata, Schübl.; inferior Oolite.

Lima recticostata, Meek.................

Pecten, n. sp..................... Pecten textorius, Goldf.; Lias and Oolite.

Pecten, n. sp......................Pecten dextilis, Münst.; Lias and Oolite.

Entolium meeki, n. sp.................Pecten demissus, Goldf.; Lias and Oolite.

Goniomya, n. sp.....................Goniomya v-scripta, Ag.; upper Lias.

Pholadomya, n. sp................. Pholadomya ambigua, Sow.; upper Lias.

Pleuromya, n. sp...................... Pleuromya striatula, Dum.; upper Lias.

Trigonia, n. sp . ................... Trigonia costata, Sow.; middle Lias.

Trigonia, n. sp . ................... Trigonia costatula, Lycett; inferior Oolite.

Cidaris, n. sp......................daris, Quenst.; upper Lias.

Glyphra punctata, n. sp ..............Glyphæa solitaria, Opp.; inferior Oolite.

I showed the unique fossil Glyphæa punctata, of which the carapace (with the exception of the tip of the rostrum) is well preserved, to Prof. Walter Faxon, of the Museum of Comparative Zoology, well known as an expert carcinologist, and he at once placed it in the Jura under the name Glyphra. G. solitaria, Opp., of the lowest Oolite, zone of Trigonia navis, is not only very close to our American form in the characteristics of the sutures of the carapace, but the surface has the rare sculpturing of punctation in place of the usual tuberculation found in most species of this genus, a peculiarity also characteristic of $G$. punctata. Such forms as these and the evidently close alliance and probable continuity of the fauna through migration with that of the Mormon sandstone suggest that the Hardgrave sandstone should be classed as upper Lias in spite of the large number of forms which are represented by species occurring also in the lower and middle Lias in Europe.

The homogeneous character of the rock and the association of fossils found in the larger masses of it led also to the conclusion that it represented only one bed in the upper Lias, but such minute researches as would have established this beyond question were not practicable.

Relation to adjacent formations.-The next sedimentary formation older than the Hardgrave sandstone is the Trail formation. They are not known to occur in contact or even near each other in the Taylorsville region, but from the fact that the Trail beds are fresh- 
water deposits and the Hardgrave sandstone marine, they may be assumed to be unconformable.

The sedimentary formation next newer than the Hardgrave sandstone is the Thompson limestone. They have not been found in actual contact, but sometimes near together, separated only by a sheet of meta-andesite. Their essentially parallel position when near together indicates conformability. The Hardgrave sandstone at several points is in contact with the Mormon sandstone, but, as we shall see later, it is the result of faulting.

The Hardgrave sandstone is almost everywhere in contact on the one hand with an ancient rhyolite and on the other with metaandesite. The metarhyolite is on the western side of the Hardgrave sandstone and lies upon it. The sandstone throughout its course in both belts dips westward beneath the ancient rhyolite and is composed, as already pointed out, of lapilli and débris derived from the rhyolite. It is therefore younger than the rhyolite, and their position has been reversed by overturning.

The contact of the Hardgrave sandstone with the meta-andesite along its eastern border is less regular than that of the metarhyolite on its western. The dip of the sandstone is west, and in many places it appears to rest directly on the meta-andesite, which passes beneath it with the same inclination. In other places-and these are important-the igneous rock breaks through the bedding and incloses many fragments of the sandstone, showing clearly that its eruption took place after the sandstone was deposited. The included sandstone fragments may be distinctly seen at an elevation of 4,100 feet in the ravine about a mile north of Donnerwirth's, as well as at other points near the contact within the area of the meta-andesite. The fragments are generally small and red, with the lithologic character of the Hardgrave sandstone, but no fossils were found in them. Though the sandstone along the contact is not clearly altered, the igneous rock is often perceptibly finer grained near the border, owing to the cooling influence of the sandstone. There seems to be scarcely room for doubt that the meta-andesite is younger than the Hardgrave sandstone.

\section{THOMPSON LIMESTONE.}

Lithologic character.-The Thompson limestone is gray and somewhat shaly, and on its weathered surface in places are round, oblong, or irregular patches of darker more or less granular calcite, which at once suggests fossils, though their specific determination is a matter of difficulty. Where shaly it is generally red, highly argillaceous, and locally full of long, slender gasteropods, which weather out and leave the porous argillaceous skeleton of the limestone full of "screw holes." 
Areal distribution and thickness.-The Thompson limestone, like the Hardgrave'sandstone, outcrops in two belts. The main belt crosses the west slope of Mount Jura, and the crest belt lies along the crest running south from the summit of Mount Jura.

The main belt is irregular and interrupted, extending south across the west slope of Mount Jura from Mr. Thompson's on North Arm to the lower slope of Grizzly Mountains, a mile southeast of Huntington's, and the most prominent and accessible exposures are near the north end, where it has been burned for lime. At Thompson's it forms a bluff, strikes $\mathrm{N} .70^{\circ} \mathrm{W}$., dips $40^{\circ} \mathrm{SW}$., and has a thickness of 30 feet.

A mile to the southeast the limestone is interrupted and offset nearly half a mile to the east. At an elevation of 4,100 feet outcrops begin again and have furnished material for lime. The mass at this point has a thickness of 40 feet and curves in position from N. $53^{\circ} \mathrm{W}$. to $\mathrm{N} .28^{\circ} \mathrm{W}$., with a dip of about $40^{\circ}$ to the southwest. It contains a number of irregular forms supposed to be sponges. The bottom layer of limestone is massive, 6 feet in thickness, and has a rough weathered surface. Below the limestone reddish and gray beds are exposed interstratified with limy layers. Above the limestone are 10 feet of red shaly limestone or calcareous shales locally full of Nerinea, the screw-shaped gasteropod to which allusion has already been made. At this locality the limestone changes its course from. southeast to southwest and follows a prominent spur toward Taylorsville. The red shaly limestone and calcareous shale is more abundant and continuous than the lentils of gray limestone, and the whole mass is folded and displaced in a complicated fashion along lines running southeast, producing a local extension in that direction before the general course is resumed a mile farther southwest. On the prominent spur running a little south of west from the summit of Mount Jura is a small isolated patch of red beds belonging to the Thompson limestone horizon. Their strike is N. $15^{\circ} \mathrm{E}$.' They are highly calcareous, fragmental in appearance upon a weathered surface, and contain small nodules and lenses of gray limestone as large as 18 inches in diameter. Traces of fossils appear in the gray limestone and also in the red beds, but none are well enough preserved for specific determination. On the next spur, half a mile farther south, is a small mass of gray limestone 10 feet in thickness with irregular cherty portions. It is directly in the course and horizon of the Thompson limestone, but no fossils were found in place at this point, though they occur near by in the talus and in place a mile farther southeast beyond the interruption. On the spur running up from the Narrows the calcareous red beds with the characteristic fossils of the Thompson limestone reappear and continue to the road above Huntington's. On the lower slope of Grizzly Mountains, in the southwest quarter sec. 7, T. 25 N., 
R. 11 E., the terminal outcrops of this belt of Thompson limestone appear in three isolated ledges lying along a line extending nearly east and west. Some of the limestone outcrops strike N. $36^{\circ} \mathrm{W}$. and $\operatorname{dip} 45^{\circ} \mathrm{SW}$., a position which connects it directly with the Thompson limestone of Mount Jura, while other portions strike N. $70^{\circ}$ E. and dip $50^{\circ} \mathrm{SE}$., probably as the result of a fault. The limestone exposed at this point ranges from 4 to 25 feet in thickness. It looks like the Thompson limestone but contains only traces of indefinite fossils. However, its general relations to other formations leave no doubt as to its horizon.

The only outcrop of Thompson limestone lying outside of the main belt just described is in the crest belt of exposures extending south from the summit of Mount Jura. It occurs near the top of the spur rising northwest from the mouth of Hinchman Ravine, at an elevation of about 5,100 feet, and contains the curious spongelike forms, while the associated red beds have definite characteristic fossils. The total thickness of the formation at this point is probably less than 20 feet and its outcrop is scarcely half a mile in length.

The Thompson limestone has not been identified anywhere beyond the immediate vicinity of Mount Jura. Considering its size and variability, this is not a matter of surprise.

Relation to adjacent formations.- The relation of the Thompson limestone to the meta-andesite that bounds it upon the west may be clearly seen on the northern slope of Mount Jura, near the end of the lime road, where the red calcareous beds, full of slender gasteropods, come into direct contact with the altered andesite. The fossils lie parallel to the surface of the volcanic rock, practically against it, without showing any alteration due to the presence of the igneous rock. This relation evidently indicates that the limestone was deposited upon the meta-andesite and is of later age. It has already been shown that the same meta-andesite is younger than the Hardgrave sandstone. The general dip of the Thompson limestone is to the southwest beneath the meta-andesite by which it is bounded in that direction, and both pass beneath the Hardgrave sandstone. All have been overturned together.

On the eastern side the Thompson limestone appears to conformably overlie the Mormon sandstone, though their actual contact is rarely exposed. A small mass of rhyolite separates them on the steep slope overlooking North Arm, but a short distance farther south they outcrop near together in parallel positions.

In SW. $\frac{1}{4}$ sec. 25, T. 26 N., R. 10 E., where the limestone turns abruptly and extends east for nearly half a mile, it appears to be held directly in a downward fold of the Mormon sandstone. The two isolated outcrops west and southwest of the summit of Mount Jura, as well as the one in the crest belt south of the summit, clearly show, 
as illustrated in fig. 11, that the Thompson limestone rests upon the Mormon sandstone, and that its taxonomic position is between the Hardgrave and Mormon sandstones. It must be remembered, however, that the strata of Mount Jura having been overturned, the younger are below.

Fossits and age.-Professor Hyatt ${ }^{a}$ refers to the Thompson limestone as the Opis bed, and remarks:

Mr. Diller's close and repeated investigations of the stratigraphy have placed the Opis bed below the Mormon sandstone in the chronologic series, and my studies, although they led me to incline to the opinion that the fauna was younger, have not succeeded in bringing to light any evidence that can be said to contradict his conclusions. The presence of a large form of Nerinea with the columella, showing the typical ridges of the normal forms of this group, indicates that this limestone is not older than the inferior Oolite, and if, as seems to be the case, it is older than the Mormon sandstone, it will probably be proved to be a member of the inferior Oolite.

A large species of $O$ pis is as abundant in some places as the Nerinea, and this genus, which is recorded in Europe as beginning in the Trias, is usually small throughout the lower and middle Jura. The only European species approximating to that of this limestone is the Opis paradoxa, as figured by Buvignier, which occurs in the Corallian of the upper Jura. A species of Terebratula, apparently identical with the large characteristic species of the Mormon sandstone, also cccurs abundantly in this bed. There are also a number of small gasteropods and other fossils requiring further investigation.

MORMON SANDSTONE.

Lithologic character.-The Mormon sandstone consists prevailingly of sandstone, passing on the one hand into conglomerate and on the other into more shaly beds. The most common and characteristic member is a gray compact sandstone so fine that to the naked eye it does not appear granular. Its color becomes brown on weathering, and the rock frequently contains casts of a small Rhynchonella. Among the grains of which it is composed there are many of quartz and of feldspar, some of which is clear plagioclase with distinct twinning lamellæ. A few are of pale-green augite, but most of them are of indefinite clouded material in which here and there small lath-shaped crystals of feldspar may be seen, indicating their derivation from igneous rocks. There is a small amount of carbonate of lime present, and it becomes somewhat more abundant in the coarser forms. The conglomerate of the Mormon sandstone is generally greenish, but sometimes reddish. Its pebbles are in a few places mainly quartzite, but at most localities they are chiefly of meta-andesite with a few of metarhyolite, and range from one-eighth of an inch to 18 inches in diameter. Several pebbles of limestone were observed, but none contained fossils. In the conglomerate are masses of fine shaly red sandstone with decided pencil structure parallel to its stratification. This same sort of material occurs also to a limited extent entirely independent of the conglomerate, and in such cases it is thin bedded and finely stratified. 
Distribution and thickness.-The Mormon sandstone, extending across Mount Jura from the lower slopes of Grizzly Mountains to North Arm, occupies a larger area than that of the Hardgrave sandstone and Thompson limestone combined. At both ends it is relatively broad, but in the middle portion it is divided into two belts, one on the west slope and the other near the crest, in positions corresponding to the two belts of Hardgrave sandstone and Thompson limestone.

At a narrow point in the wavy belt across the western slope of Mount Jura the following section was observed: Adjoining the eastern side of the Thompson limestone is 45 feet of massive gray sandstone with a rich fauna. This is succeeded farther up the slope by 30 feet of conglomerate and finally by about 20 feet of finely stratified red shaly sandstone, the "Inoceramus bed" mentioned by Professor Hyatt. The total thickness of this belt a short distance farther south increases to about 225 feet and the conglomerate becomes more prominent, but farther along again diminishes and is scarcely noticeable near the south end.

The crest belt, long and narrow, running south from the summit of Mount Jura is well exposed on the steep slopes facing Hinchman Ravine, and affords the following section: Adjoining the Thompson limestone is a mass of greenish conglomerate 150 feet in thickness. Part of it is coarse and it includes much andesitic material. Some greenish sandstone is interstratified with the conglomerate. Below this is a gray sandstone 400 feet in thickness well characterized by the little Rhynchonella. It includes some shaly beds and near the bottom traces of conglomerate. The total thickness, 550 feet at this point, is much greater than that on the western slope of Mount Jura.

The curved area on the lower slopes of Grizzly Mountains opposite the mouth of Hinchman Ravine is chiefly gray sandstone and represents the union of the crest belt and that which crosses the western slope of Mount Jura. Besides the characteristic Mormon sandstone fauna which it contains there are traces of other fossils, and it is possible that some Hardgrave sandstone is here included in the area marked Mormon formation.

The largest area of the Mormon sandstone lies on the north slope of Mount Jura, stretching from the summit to North Arm. It is chiefly gray sandstone but includes also a large amount of conglomerate, which occurs at various horizons in the mass. Near the western border, under the Thompson limestone, there is locally a small amount of conglomerate, in which the fine greenish cement and many of the smaller pebbles are composed almost wholly of andesitic material. Reddish conglomerate and red beds occur in the middle of the Mormon sandstone on the steep slope southeast of Thompson's, but the most important outcrop of conglomerate is nearly a mile farther east, on the edge of the valley about Lucky S road. It strikes $\mathrm{N} .27^{\circ} \mathrm{W}$. 
and dips $62^{\circ} \mathrm{SW}$., and the mass is extremely variable in its composition, varying from thin lenses of red shaly sandstone with prominent pencil structure to coarse conglomerate in which some of the pebbles are 18 inches in diameter and the material almost wholly andesitic in character.

The only area of the Mormon sandstone yet to be noted is a small one which is entirely isolated. It occurs about 4 miles northeast of Mount Jura, in sec. 17, T. 26 N., R. 11 E., and contains compact gray sandstone well characterized by fossils. This mass of the Mormon sandstone is much more disturbed than the others. The sandstone is much fractured, permeated by small quartz veins, and along the western border is greatly sheared, producing slickensided slaty material.

Fossils and age.-Concerning the fossils of the Mormon sandstone, Professor Hyatt, ${ }^{a}$ in his paper on the Taylorsville region, reports as follows:

This bed contains the remains of a more varied fauna than that of the Hardgrave sandstone. In some places, especially upon spur 8 of Mr. Diller's map, the fossils are in excellent preservation; but in some localities merely superficial work does not give good results, the rock being apt to be very friable. Here as elsewhere the greatest treasures await resurrection at the hands of those able to dig deeply into the stony matrix.

It is more difficult to point out the characteristic fossils in this bed than in the Hardgrave sandstone. Lima dilleri and L. taylorensis, Ctenostreon, Trigonia, and Entolium are apt to occur in all the outcrops. So far as the determination of age is concerned, however, the Ammonitinæ, although not abundant, afford the best evidence. These highly specialized forms, as has been pointed out by several of the most distinguished paleontologists in Europe, must have been extremely sensitive to the influence of the changes of the surroundings in passing from one geologic level to another, and have recorded these mutations in their own organizations. Even the encyclopedic Quenstedt continually expresses his satisfaction in turning from the uncertain indications afforded by the more generalized structures of other mollusca to the decisive chronologic evidence usually given by the fossils of this group. The list printed below contains a series of selected species, but many forms, especially among the smaller Pelecypoda, which have not yet been studied, are necessarily omitted.

Taylorsville, Cal.

Europe.

Terebratula........................ Terebratula perovalis, Sow., as figured and described by. Quenstedt, is similar, but the American species has no dwarfed varieties; inferior Oolite.

Rhynchonella, n. sp.................... Rhynchonella quadriplicata, Zeit., as figured and described by Quenstedt; great Oolite.

Alectryonia, n. sp ................... Orthis marshii, Goldf., as figured by Mor. et Lyc. in Oolite Mollusca; inferior and great Oolite.

Modiola subimbricata, Meek, and also other species of the same genus similar to this, but having shorter and broader shells.

Modiola imbricata, Sow., and other species of Modiola, with heavy umbonal ridges, occurring in the inferior and great Oolite. 
Mytilus, n. sp....................Mytilus sublævis, Mor. et Lyc., and other species, having arcuate forms and heavy; umbonal ridges, which are characteristic of the Oolite.

Pinna cuneiformis, n. sp...............Pinna cuneata, Phill., as figured by Mor. et Lyc. in Oolite Mollusca; inferior Oolite.

Pteroperna, r. sp.................. Stands between Pteroperna plana and Pteroperna costatula, Mor. et Lyc.; inferior and great Oolite.

Gervillia, n. sp........................Gervillia lanceolata of the upper Lias, but longer and narrower in proportion, and the posterior wing larger. It is in fact a more progressive form in the same series of species than Gervillia lanceolata.

Gervillia, n. sp......................Gervillia aviculoides, Sow.; great Oolite.

Lima dilleri, n. sp..................... Lima cardiiformis, Sow.; great Oolite.

Lima, n. sp........................ Lima tenuistriata, Münst. and Goldf.; inferior Oolite.

Lima taylorensis, n. sp..................Lima rigidula, Mor. et Lyc.; great Oolite.

Ctenostreon, n. sp.....................Ctenostreon pectiniformis, Mor. et Lyc.; inferior and great Oolite.

Pecten, n. sp......................... Pecten disciformis, Schübl.; inferior Oolite.

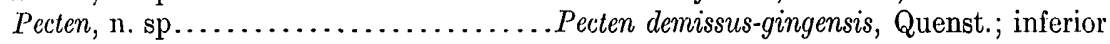
Oolite.

Pholadomya, n. sp ...................Pholadomya fidicula, Zeit.; inferior Oolite.

Trigonia, n. sp....................... Trigonia hemispherica, Lyc.; inferior Oolite.

Trigonia, n. sp...................... Trigonia formosa, Lyc.; inferior Oolite.

Belemnites, n. sp.................... Belemnites breviformis, Voltz.; upper Lias to inferior Oolite.

Spheroceras, n. sp..................Sphæroceras gervilli; inferior Oolite.

Grammoceras, n. sp.................. Grammoceras toarcense, as figured by Buckman; inferior Oolite.

Grammoceras, n. sp...................Grammoceras leurum, Buckm.; inferior Oolite.

The fossils indicate the former existence of a fauna which can be provisionally considered as belonging to the upper part of the inferior Oolite.

Inoceramus bed.-Immediately above the Mormon sandstone with its rich fauna there are strata of a red sandstone containing very few remains and these usually in poor condition. Three species of fossils were found in them: A Terebratula, apparently the same as that occurring so plentifully in the typical Mormon sandstone; two fragments of a large species of Inoceramus; and a fragment of an ammonite of the genus Perisphinctes. The Inoceramus of the Jura is not so large in the Lias as in the Oolite, and these fragments appeared, therefore, to have belonged to shells at least as old as the Oolite. The specimen of the Perisphinctes may prove to be identical with some species found below. It is probable, therefore, that this bed belongs, as in fact is indicated by the geology, to the upper part of the Mormon sandstone. On the other hand, the fact that one out of the three species was new to the fauna of the Mormon sandstone justifies a provisional separation under a different title on biologic grounds. Even if not sustained by future work, this distinction will serve a good purpose if it succeeds in calling the attention of collectors in the same or other localities to facts that might otherwise escape their notice.

Relation to adjacent formations.-The Mormon sandstone is in conformable contact with the Thompson limestone, though it marks a decided change in the character of the sediment from fine calcareous 
to coarse fragmental derived chiefly from altered andesitic rocks. This relation may. be best seen on the southwest slope of Mount Jura near Donnerwirth's, where the positions of both the above-named formations are practically parallel to that of the adjacent Hardgrave sandstone.

The isolated mass 4 miles northeast of Mount Jura rests unconformably upon the Hosselkus limestone, as shown in fig. 6, without the intervening Triassic and Jurassic strata: This discordance, however, is not of deposition but of dislocation along a line of extended faulting.

The relation of the Mormon sandstone to the later formations will be considered in connection with the Bicknell sandstone.

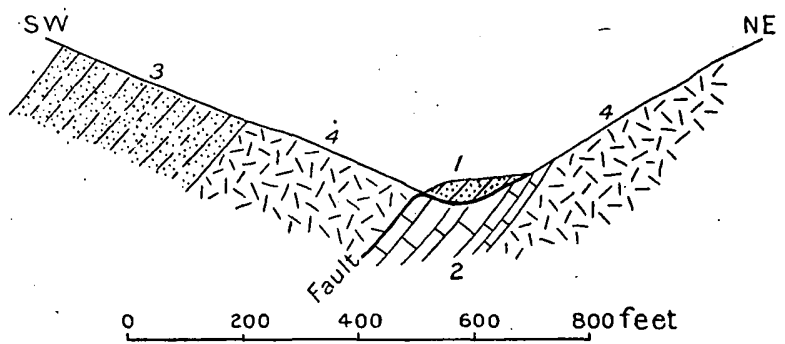

Fig. 6.-Relation of Mormion formation to Hosselkus limestone. 1, Mormon sandstone; 2, Hosselkus limestone; 3 , Robinson formation; 4, eruptive rocks.

BICKNELL SANDSTONE.

Lithologic character.-The Bicknell sandstone is composed chiefly of red and gray sandstone associated with some dark shales and tuffaceous beds. The dark brownish-red sandstone is largely feldspathic and contains much red oxide of iron with more or less carbonate of lime. It somewhat resembles the red Hardgrave sandstone; but is darker colored, and though much of its material may be derived from igneous rock, its particles are not characterized by the presence of numerous small crystals of feldspar as in the Hardgrave sandstone. Sandstones, mottled gray and red, form transitions to the gray sandstone which is the most abundant rock of the formation. Much of it is fine dark bluish gray, very compact and hard, breaking with a conchoidal fracture, and flecked here and there by small particles of pyrite. It looks so much like hornfels that one is surprised to find it locally full of large shells. Associated with this form is more or less black shale, some beds of which weather white and look like fine volcanic dust. A thin section, however, shows no characteristic volcanic material, but instead extremely fine sediment with a multitude of minute microscopic crystals of rutile which have developed in the sediment since it was laid down.

A coarser variety of the sandstone is light gray or greenish and passes into a rock which is full of small white crystals of feldspar with 
a few scales of gray mica embedded in a dark groundmass, and the general aspect is decidedly igneous. The fact that it contains distinct fossils shows that it is fragmental, and it locally becomes coarse, so that its real character is more evident. In thin section under a microscope the fine fossiliferous rock is clearly fragmental, and much of the sediment was evidently derived from the erosion of volcanic rocks.

Distribution and thickness.-The Bicknell sandstone is much more regular in its distribution than the other Jurassic formations already noted and forms a continuous belt from the mouth of Hinchman Ravine across the east and north slopes of Mount Jura to North Arm of Indian Valley. Its greatest development appears to be on the southeast slope of Mount Jura, which is the only portion that is well characterized by fossils.

The reddish sandstone is the earliest portion of the Bicknell sandstone and lies near the west border of the mass. It is best exposed along the crest north of the summit. The compact fine dark-gray sandstone with the black shaly portions interbedded with gray sandstone forms the middle portion of the mass and becomes more tuffaceous along the east border where it adjoins the Hinchman standstone.

The thickness of the Bicknell standstone on the southeast slope of Mount Jura, where its greatest development occurs, is probably over 1,000 feet. From this point it appears to decrease in magnitude to the north and south so as to average less than 500 feet in thickness.

The general attitude of the Bicknell sandstone is like that of the Hardgrave, Thompson, or Mormon formations already noted. With but few exceptions it strikes west of north and dips southwest beneath Mount Jura.

Fossits and age.-In this sandstone fossils are neither so generally distributed nor so ábundant as in the other Jurassic formations already noted: None have been found north of the summit of Mount Jura. Regarding this Professor Hyatt ${ }^{a}$ says:

The fauna of the Bicknell standstone is not so rich in species as are the Mormon and Hardgrave sandstones and the Thompson limestone, nor are the fossils so plentiful. The character of the rock in the surface exposures found by the party made it almost impossible to get out large specimens in perfect condition. Nevertheless, a sufficient number of molds of several large species of Trigonia (T. obliqua and T. plumasensis) and some well-preserved specimens of Gryphxa bononiformis were secured, all of which are more or less characteristic of the youngest faunas of the Jura in Europe.

The remains of the Ammonitinæ are fragmentary, but those that were found certainly indicate a somewhat older fauna than the species above named. There are a number of the molds Rhacophyllites with the internal septa partly preserved, a fragment of a Reineckia, two rather poor molds of Macrocephalites (?), and several fragments of Perisphinctes. These form an association which gives strong support to the provisional opinion that the fauna is really synchronous with that of the Callovian// the oldest

a Bull. Geol. Soc. America, vol. 3, 1892, p. 406.

50007-Bull. $353-08-4$ 
fauna of the upper Jura, or Malm, in Europe. The specimens of Chemnitzia are molds of a very large shell, but unluckily co not show the aperture. The only species in Europe which appears to be a close ally of this is also from Callovian.

The list below gives a very inadequate idea of the fauna, since none of the belemnites or Ammonitinæ can be directly compared with European species on account of the need of more perfect specimens and are, with one exception, not mentioned. There are also a large Nerinea and a few species of Pelecypoda and Brachiopoda, which were not considered important in this preliminary notice.

Taylorsville, Cal.

Europe.

Gryphaa bononiformis, n. sp............ Ostriea bononia, Sauv., as figured by de Loriol et Pellat; Portlandian.

Entolium costatum, n. sp.

Oxytoma, n. sp.

Trigonia obliqua, n. sp................. Trigonia michelloti, de Loriol; Portlandian.

Trigonia plumasensis, n. sp..............Trigonia lusitanica, as figured by Choffat; Portlandian.

Trigonia naviformis, n. sp.............. Trigonia navis; inferior Oolite.

Chemnitzia, n. sp................... Chemnitzia athleta, d'Orb.; Corallian.

Rhacophyllites, n. sp.

The group of Trigonia glabræ to which T. obliqua belongs reached its acme in the Portlandian, the species being both rare and comparatively small in the Lias and inferior Oolite. T. obliqua is of extraordinary size and shows the incomplete costæ of the Portlandian species. The group of Trigonia to which T. plumasensis belongs is very peculiar in the characteristics of the costæ and the ornamentation of the anal area, and it has hitherto been represented in Europe only by' the unique form, T. lusitanica, found only in the highest Jura of Portugal. Besides these two large species there is also in T. naviformis an equally large representative of another peculiar and hitherto unique style of ornamentation. This, as its name implies, is similar to T. navis of the inferior Oolite in Germany, a species hitherto considered to be the only representative of a very distinct group, the Trigonia schapoidæ, and having a pattern of costation not found in any other species (except $T$. naviformis) and a narrow chorologic range.

The group of the Trigonia.undulatx is represented by a species also of extraordinary size, but the Trigonia clavellatx, the group more largely represented than any other in the inferior Oolite (if one can judge from the simple specimen obtained in the Bicknell sandstone) is not materially modified.

Bicknell tuff.-Above the sandstone and in immediate contact with it is a tuff described by Mr. Diller, which contains in part the same species as the sandstone, and the fossils indicate the same fauna. Nevertheless, it should be noticed that it contained no remains of Trigonia, and that the fauna has not been critically, examined.

Relation to adjacent formations.-As to the relation of the Mormon and Bicknell sandstones, observations are not so definite, though they point to conformity. Upon the south slope of Mount Jura, as well as upon its north end, the two sandstones are separated by a belt of meta-andesite, but for nearly a mile north of the summit they appear to be in conformable contact. The actual contact was not observed, but throughout the two formations appear in parallel position. The adjoining formations are connected by transitional sediments and there is no decided interruption visible between them excepting a change in fauna. 


\section{HINCHMAN SANDSTONE.}

Lithologic character.-'The Hinchman sandstone is composed essentially of coarse sandstone with shaly parts and some conglomerate which is generally fine and derived chiefly if not wholly from andesitic rocks. Much of it is decidedly tuffaceous. The most common form is greenish gray and contains darker colored shaly patches, but is not conspicuously fragmental. If Examined microscopically it is found to be made up largely of fragments of feldspar, augite crystals, and varying proportions of andesitic rock, fragments of which are clearly microporphyritic. The feldspar is generally much altered. Some of the augite is fresh, but most of it is altered to chlorite, giving a greenish color to the rock. It is never coarse like volcanic agglomerate, though it is sometimes made up largely of ejected volcanic material, some of which is clearly pumiceous. The grains are rarely well rounded by attrition, though it is evident that they have been transported and loosely aggregated on the sea floor, affording corners and cavities where corals, belemnites, and a number of other marine forms flourished. Remains of these animals are not confined to one horizon, but are scattered throughout the formation. The conglomerate locally. becomes coarse and composed of pebbles, some of which are well rounded; others are angular. The largest pebbles are rarely a foot in diameter. One of the most abundant types is a reddish, decidedly microporphyritic andesite. Others less common are dark and macroporphyritic, with either feldspar or hornblende phenocrysts. Limestone pebbles or nodules occur sporadically, but none could be found with fossils.

Distribution and thickness.-The outcrop of the Hinchman sandstone is confined to the slopes of Mount Jura, and stretches in one continuous belt from the mouth of Hinchman Ravine to the borders of North Arm, Like the other formations of Mount Jura its general strike, without much variation, is a few degrees west of north and its dip to the southwest. Its best exposures are at Curtice Cliff, in the lower part of Hinchman Ravine, where most of the fossils were collected, though they occur also along the crest on the northern slope. The greatest variation from the normal Hinchman tuffaceous sandstone occurs in the coarse conglomerate with well-rounded pebbles along the west slope of South Fork of Foremans Ravine. This conglomerate somewhat resembles that of the Mormon formation exposed by the Lucky $S$ road on the flat near Foreman and its strike appears to connect it with that mass. No fossils could be found in it, and the stratigraphy of the west slope of the South Fork of Foremans Ravine places it in the upper part of the Hinchman sandstone as here considered. This conglomerate ranges from 50 to nearly 200 feet in thickness and was not recognized in Hinchman Ravine, where the tuffaceous portion of the formation has its greatest development and attains a thickness of 500 feet. 7 
Fossils and age.-The most widely distributed and characteristic fossils of this horizon are corals which Professor Hyatt relegates to the genus Stylina and has designated the bed in which they occur "Stylina bed." He reports further ${ }^{a}$ in the paper previously referred to that-

The presence of the same species of Rhacophyllites as that found in the Bicknell sandstone indicates the continuity of the fauna of this bed with that of the preceding; but, on the other hand, the absence of Trigonia and the presence of close allies of Ostræa bruntrutana and of Pecten suprajurensis, shows that we have ascended in time to a younger fauna. (The abundance of corals of the genus Stylina, these being the most widely distributed and characteristic fossils of the Hinchman tuff, shows that the age is probably that of the Corallian.| In Europe these corals are rare in the Oolite, but reach their acme in numbers of species and forms in the Corallian of the upper Jura: The opinion expressed with regard to the age of the Bicknell sandstone is greatly strengthened by this fact, and it also adds to the evidence that the subdivisions of the Jura in North America and in Europe, like those of the Trias, may be compared much more closely than one would at first suspect from the extremely fragmentary records heretofore found in this country.

The fossils occurred in patches and, although abundant, good specimens were not easily obtained. The list is as follows:

Taylorsville, Cal.

Europe.

Gryphæa curtici, n. sp ................ Ostræa bruntrutana, as figured by de Loriol; Corallian to Portlandian.

Camptonectes bellistriatus, Meek..........Pecten suprajurensis, Buvignier; Kimmeridgian.

Chemnitzia. .................... Chemnitzia athleta, d'Orb.; Corallian.

Rhacophyllites (same species as in the Bick-

nell sandstone).

Stylina tubulifera.................. $\left\{\begin{array}{l}\text { Stylina tubulifera, Ed. et H.; Corallian. } \\ \text { Astrea tubulifera, Goldf.; Corallian. }\end{array}\right.$

Stylina subjecta, n. sp.................. Closely allied to a specimen in Museum of Comparative Zoology named S. echinulata, Lmk.; Corallian.

Stylina alba, n. sp

Stylina minuta, n. sp.................. Resembles the Cretaceous species figured by Goldfuss as Astrea geminata (equal $S$. geminata, Ed. et H.), but septa are not so

Stylina intermedia, n. sp.

Stylina tertia, n. sp. symmetrical.

Two species of Belemnites and a number of gasteropods, pelecypods and brachiopods were also found in this bed.

Relation to Bicknell sandstone.--The Hinchman and Bicknell sandstones are conformable and connected by intergradation, so that, though the Bicknell sandstone is prevailingly fine and the Hinchman prevailingly coarse tuffaceous sandstone, there is no sharply traceable boundary between them. The general lithologic differences, in addition to the faunal contrasts pointed out by Professor Hyatt, furnish sufficient grounds for distinction. Nevertheless, these two formations have greater similarity than any other two of Mount Jura. 
Lithologic character.-The Foreman formation is a succession of shale, sandstone, and conglomerate in which the sediment is for the most part derived from rocks which are not clearly volcanic. The shales are often slaty and locally have "pencil structure," and range in color from dark carbonaceous with traces of leaves through gray, which predominates, to shades and tints of red and yellow. A remarkable feature of the shales locally is their pencil structure, which is particularly well developed in the summit of Evans Peak. 'The beds of red and gray sandy shales making the summit of the peak break up into small columns, often of lead-pencil size, but generally smaller. They are less commonly larger, reaching a maximum length of 7 inches and a diameter of about half an inch. The pencils are commonly four sided and diamond shaped or rhombic in cross section, but occasionally they have three or five sides.

Almost as abundant as the shales are the sandstones, most of which are very fine and decidedly shaly. They are reddish brown and gray, sometimes mottled with darker spots, chiefly carbonate of lime. These spots weather out more easily than the other parts and leave the rock with occasional holes in its surface. Occasionally the gray sandstone is more siliceous and contains irregular particles which give to the mass the appearance of a fine tuffaceous conglomerate.

Conglomerate is less abundant than either shale or sandstone and is usually in thin beds of small extent scattered throughout the formation. The most characteristic conglomerate of this formation is composed almost wholly of small pebbles of cherty quartz, black and gray in color, and rarely over half an inch in diameter. Of this there are but few beds ranging from 5 to 12 feet in thickness. A more abundant form of conglomerate contains locally many shale fragments and well-rounded pebbles chiefly of meta-andesites and rhyolites, with a few of fossiliferous limestone. The majority of the beds are small and are made up of small pebbles, rarely as large as $3 \frac{1}{2}$ inches in diameter. Associated with the limestone pebbles in the conglomerate are concretionary nodules of carbonate of lime, which occur also in the shale and sandstone. They do not contain fossils and grade into the inclosing rock instead of having a sharp contact, as is the case with the limestone pebbles.

Distribution and thickness.-The Foreman formation occupies a larger area than all the other Jurassic formations of that region combined, and extends from Genesee Valley northwest to Mountain Meadows, a distance of 13 miles. Two interruptions occur in the belt, one near Hinchman Ravine by meta-andesite, and the other at North Arm, where it is covered by alluvium. At the northwest end of the exposure the Foreman beds disappear in the same way by passing beneath the alluvium of Mountain Meadows and the lavas ! 
of the great volcanic field beyond. The small area on the border of North Arm, a mile north of Peters Creek, is the edge of a large connecting mass which underlies the alluvium of North Arm, but the two small areas, one on Lights Creek and the other on Surprise Creek, are entirely isolated. Though the formation is composed of interstratified shale, sandstone, and conglomerate throughout, these rocks are so distributed that the formation may be roughly divided into three members of about equal thickness. The upper or oldest mem-

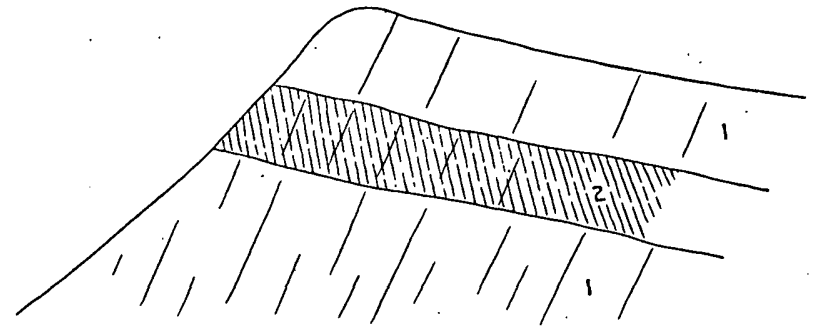

Fig. 7.-Section of interbedded shale and sandstone of Evans Peak, showing relation of joint and pencil structure. 1 , Jointed structure of sandstone and shale; 2 , pencil structure of shale.

ber, along the west border of the formation, is composed very largely of dark shale with a few beds of fine cherty quartz conglomerate and contained nearly all the fossils thus far collected from the formation; the middle member is chiefly gray sandstone with a few traces of fossils, while the lower or youngest member, lying along the east border, is made up largely of gray shales and as far as yet known is without fossils.

The Lucky S road affords a good section of this formation, especially of the cherty conglomerates, in its older portion near the western

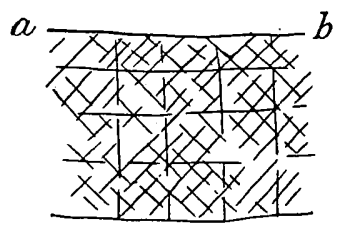

FIG. 8.-Plan of pencil structure on plane of stratification. $a-b$, Strike. border; but the most continuous exposures occur on the steep slopes of Evans Peak, where 1,600 feet of strata outcrop. All three members are well exposed in the Evans Peak section, and shales predominate, interstratified with sandstone and numerous layers of conglomerate. As already noted, the shales are remarkable for their highly developed pencil structure. The shales dip to the southwest and are cut by joints having about the same strike and a somewhat steeper dip to the northeast. The joint planes are usually very rough, due to the impinging of the pencils, which are vertical. The general relations of the stratification to the jointing and the vertical pencils are shown in fig. 7, and the plan of the pencil-making fissures on the plane of stratification in fig. 8. The planes bordering the pencils are not clearly slickensided, and yet they may have been planes of motion to produce the several sets of slaty cleavage which divide the mass 
into pencils. The pencil structure of the sandy shales, although best developed on the slopes of Evans Peak, occurs on Peters Creek and elsewhere locally in the finer sediments of the Robinson beds, as well as in the formations of Mount Jura.

Fossils and age.-Fossil plants were discovered near Foreman in dark shale close to the west border of this formation by Cooper Curtice in 1890, and at a later date the small collection was somewhat enlarged by E. G. Paul and James Storrs. Professor Fontaine studied the collection and described ${ }^{a}$ the plants, and his conclusions are as follows:

The plants are very fragmentary, and most of them are poorly preserved. The most distinct are a small Equisetum and several ferns with small pinnules. The ferns are the most numerous, but unfortunately they present mostly such portions as the tips of pinnæ and detached fragments of pinnæ. The amount of material is not sufficient to enable one to determine with positiveness their relations to previously described forms, for ferns are so notoriously variable in foliage that a considerable amount of material is needed to make reliable determinations. Still, taking the collection as a whole, and looking to the nearest relationships with previously known fossil plants, we may arrive at some results with a considerable degree of certainty.

The plants are certainly younger than Paleozoic, and as the elements of the flora are ferns, equiseta, cycads, and conifers, with no trace of dicotyledons, they are Mesozoic, most probably older than Cretaceous, with the possible exception of its very base.

Owing to the imperfection of the material and the absence of the type forms, I can not come to a positive conclusion as to the exact position in the-Mesozoic of these plants, but I think the weight of evidence is strongly in favor of the flora being Rhætic or uppermost Trias.

In a paper on the geology of the Taylorsville region of California, ${ }^{b}$ the Foreman beds, on the evidence afforded by the plants, were relegated to the top of the Triassic. At that time only a few traces of fossil animals were known in the Foreman beds. A belemnite, a gasteropod, and a cast of a bivalve shell, with traces of plants, had been found about a thin layer of dark bluish limestone at the head of Starks Ravine, near the south line of sec. 35, T. 27 N., R. 10 E., about 3 miles southeast of Evans Peak.

Further collections of fossil plants were made at the same locality by James Storrs in 1904 and submitted to F. H. Knowlton, who reports as follows:

Acrostichites? princeps (Presl.) Schenk. $\mid$ Equisetum munsteri (Stb.) Brongn.

Acrostichites brevipennis Ward.

Sagenopteris? sp.

Podozamites? sp.?

Conifers? fragments.

These determinations are based on Fontaine's identifications of the earlier material from the same locality, as recorded in Ward's Status of the Mesozoic Floras, First Paper, pages 333, 334. I have not looked far enough into the question to have an opinion as to the bearing of these plants on the age, but I may say, after looking rather hastily over the earlier material, that I incline to question several of Fontaine's generic determinations. His Podozamites? taylorvillensis is certainly a Pterophyllum, his Sagenopteris looks to me like Glossopteris, and his Acrostichites may prove to be Gleichenia or Gleichenopsis. (February 8, 1905.) 
The discovery of shells at a new locality in this formation by James Storrs in 1904 affords more important data for reference to a definite horizon. The shells occur in the older portion of the formation, near the plant beds, in approximately the same horizon as those of Starks Ravine. They were studied by T. W. Stanton, who reported January 20, 1905, as follows:

The fossils were compared with the earlier collections from the same region studied by Professor Hyatt, and it was thus practicable to confirm Mr. Diller's field determinations of horizons, although in most cases the fossils are not specifically identified because the species have not been described.

The only impcrtant change in our ideas concerning the relations of the various Mesozoic formations of the region is caused by the collection from the Foreman beds (No: 6776). This formation has previously yielded only a few fragmentary plants which were supposed to be Upper Trias (Rhætic). The present collections of marine invertebrates is sufficient to prove that at least a part of the formation is Middle Jurassic or later.

The following lists, with brief comments, will indicate the character of the collection from each locality:

6776. South fork of Foremans Ravine, 3 miles northeast of Taylorsville.

Pecten sp.

Trigonia naviformis Hyatt ?. . Fragments of this or a closely related species.

Astarte sp.

Perisphinctes ? sp............ Imprint.

Ammonites :............. Imperfect imprints of two genera.

Belemnites............... Imprint.

Several undetermined small pelecypods and gasteropods; represented by casts and imprints.

This lot differs lithologically and in general faunally from any of the known fossiliferous horizons of the Taylorsville Jurassic.

The Trigonia is convincing evidence that the bed from which it came is later than the Triassic, and the close relationship, if not identity, of this Trigonia with T. naviformis, as well as the character of several of the other forms, indicates that the horizon is in the Jurassic and later than the Hardgrave sandstone-possibly later than the Bicknell sandstone.

In reply to my question as to the faunal relation of these beds to the Hardgrave sandstone, Stanton stated that they may well be the youngest Jurassic beds of the region, even younger than the Hinchman. This statement of Stanton is confirmed by the stratigraphy of the region, which places the Foreman beds next younger than the Hinchman sandstone.

Relation to adjacent formations.-The general strike of the Foreman beds is northwest and the dip is to the southwest immediately beneath the Hinchman sandstone and all the other formations of Mount Jura which have been overturned. The contact between the Foreman and Hinchman strata is locally very irregular along the east side of Hinchman Ravine, and the lack of accord in the strikes of the two formations suggests a slight unconformity. Completely satisfactory evidence on this point could not be obtained, though it is supported by the fact that in the hills just east of Foreman the 
Foreman beds unconformably overlap the Mormon formation without the intervening Bicknell and Hinchman sandstones. Farther northwest, beyond North Arm, the Foreman beds come in direct contact with the metarhyolite and the Robinson formation without any intervening Jurassic and Triassic strata. Northeast of Mount Jura, at the head of South Fork of Foremans Ravine, the Foreman beds unconformably overlap the Peale formation of Carboniferous age but do not come in contact with any other sediments in that locality.

As bearing upon the unconformity between the Foreman beds and the Carboniferous formations, it may be noted here that fossiliferous limestone pebbles were found in the conglomerate of Evans Peak. In them Girty reports Diphyphyllum sp., Amplexus? sp., and Arch $x-$ ocidaris sp., and remarks that they are "certainly Paleozoic and probably Carboniferous."

SOUTHERN EXTENSION OF THE TRIASSIC AND JURASSIC ROCKS OF THE TAYLORSVILLE REGION.

The Mesozoic formations of the Taylorsville region are cut off by igneous rocks before reaching the fortieth parallel. Next south of that line is the Downieville quadrangle, which has been mapped and described in a folio by H. W. Turner. He recognizes two formations in the "Juratrias." The lower he regards as closely related to the Sailor Canyon formation, and the upper he designates the Milton formation. The distribution of these two formations, as far as it has been possible to separate them, is shown in $\mathrm{Pl}$. I.

\section{SAILOR CANYON FORMATION.}

The lower portion is composed chiefly of siliceous argillite with some coarser sediments in part volcanic, and a layer of fine breccia of gray fragments in a dark matrix which contains radioiarian remains. An ammonite was found in the siliceous slates, which shows that they are closely related to the Sailor Canyon beds which Waldemar Lindgren discovered in the Colfax and Truckee quadrangles south and southeast of Downieville.

According to Lindgren black calcareous shale without pronounced fissility, interbedded with subordinate strata of quartzite and limestone possibly to the thickness of 6,000 feet, is well exposed with easterly dip along North Fork of the American River in the neighborhood of New York and Sailor Canyon, where the lower part contains numerous imperfect ammonites and shells of Daonella and Monotis. The basal bed is a closely packed conglomerate of chert and slate, and all the relations observed on the American River Lindgren thinks "point strongly to an unconformity between the Juratrias and the Carboniferous." 
The fossils and the lithology of the Sailor Canyon beds on American River at once suggest the Swearinger formation to any one familiar with the Taylorsville region, but this may be deceptive. Professor Hyatt, who has made a thorough study of the fossils from both localities, remarks ${ }^{a}$ that "the entirely distinct species of the two localities, even in the genera Monotis and Daonella, show that there were two distinct faunal areas, and that there could have been no communication between them during the time of the deposition of the Monotis and Daonella beds, even if it is admitted that they were contemporaneous in deposition, an opinion which can not be maintained by any facts now known."

\section{MILTON FORMATION.}

Turner describes the formation as made up "largely of tuffs, all of which, being evenly stratified, present the appearance of having been laid down in water. These beds contain igneous fragmental (pyroclastic) material of the augitic greenstone series, quartzite, fine red slates, a little marble, and a variegated breccia or conglomerate." The limestone contains garnet and wollastonite and the sandy sediments brown mica developed under the metamorphosing influence of the adjacent granitic intrusions. The Milton formation, Turner states, is distinctly later in age than the siliceous slates (Sailor Canyon) and are probably Jurassic. A comparison with the Taylorsville section suggests that they may be the equivalent of the Trail formation, which is of fresh-water origin and contains much pyroclastic material with other sediments and few fossils.

In the northwest portion of the Truckee quadrangle masses of diabase and diabase porphyry intercalated in the slates and tuffaceous rocks are of frequent occurrence, and Lindgren suggests that they may be the Milton formation.

On the general geologic map of the Lassen Peak region and the northern end of the Sierra Nevada the Sailor Canyon beds are mapped as Triassic and the Milton as Jurassic. Lindgren and Turner pointed out that these rocks are much less compressed than those of Paleozoic age. These Mesozoic rocks dip eastward and appear to be conformable throughout, but rest with marked unconformity upon the Carboniferous rocks.

A short distance east of the area covered by the general map (Pl. I), in western Nevada, are a number of localities at which fossiliferous Triassic and Jurassic strata have been founck The most important Triassic areas are a few miles southeast of Dayton, near Volcano, 30 miles northeast of Walker Lake, at New Pass in the Desatoya Mountains, and especially at Star Peak near Humboldt, a locality made famous by the work of the Fortieth Parallel 
Survey. At all of these localities the fossils indicate, according to Professor Hyatt ${ }^{a}$ and James P. Smith, ${ }^{b}$ a horizon lower than the Hosselkus limestone, about the position of the Pit shales so well exposed in the Redding quadrangle. Lindgren has shown ${ }^{c}$ that in northeast Oregon and the adjoining portion of Idaho the Triassic, like that of the Taylorsville and Redding regions, is well developed, suggesting connection with the great masses of British Columbia. At Soda Springs, Idaho, about 100 miles north of Ogden, a still lower horizon of Triassic occurs. It is the oldest known in the Nevada basin region. This basin contains also Jurassic strata. As shown by Hyatt, the fauna of the Hardgrave formation of Taylorsville occurs at Volcano, 30 miles east of Walker Lake in Nevada, and at Bear Creek in the Blue Mountains of eastern Oregon, and he asserts " that "it is obvious that there was no barrier between these. three littoral faunas at the time of the deposition of the upper Lias of Taylorsville and that the three basins were contemporaneous and connected."

\section{RELATION OF THE TAYLORSVILLE JURASSIC TO THE MARIPOSA.}

The latest conclusion of Professor Hyatt concerning the relative age of the Jura-Triassic rocks of the Sierra Nevada ${ }^{e}$ places the Hinchman formation about the middle of the upper Jurassic next older than the Mariposa formation that lies toward the base on the west slope of the Sierra Nevada. He remarks the distinctness of their faunas. The areal relation of the two formations at their nearest approach is shown on the general map, Pl. I. The fauna of the. Foreman beds had not been discovered when Professor Hyatt wrote, and it seems very probable that a thorough study of it by a paleontologist in the field may bring the Foreman beds, the latest Jurassic of the Taylorsville region, and the Mariposa still closer together.

The Mariposa formation outcrops on the western slope near the foot of the Sierra in several long, narrow areas approximately parallel to the range. To the northwest of Mariposa, one belt of exposures ends near Folsom and the other near Colfax. Farther in the same direction, near Oroville, some black slates containing a remarkable flora have been called Monte de Oro formation hy Turner. ${ }^{f}$ Their lithologic similarity to the Mariposa is striking and their flora is thought by the paleobotanists to indicate about the same horizon.

a Buil. Geol. Soc. America, vol. 5, 1894, p. 400.

b Jour. Geology, vol. 6,1898 , p. 778 .

c Science, new ser., vol. 13, 1901, p. 270.

a Op. cit., p. 401.

e Op. cit., pp. 412-413.

$f$ Seventeenth Ann. Rept. U. S. Geol. Survey, pt. 1, 1896, p. 548. A fuller account of this formation is in course of publication by the present, writer in the Bulletin of the Geological Society of $A$ merica, vol. 19. 
In these plant beds, however, some invertebrate fossils have been recently discovered by James Storrs and they throw new light on the age. Concerning Storrs's collection T. W. Stanton reports (February 3, 1908) as follows:

About a year ago, in reporting on another collection obtained by Mr. Storrs from these beds, I expressed the opinion that they are Jurassic, and older than the Mariposa beds. The fossils now under examination add several species to the previous list, although I am still unable to assign them to described species, and they do not therefore afford a good basis for correlation with well-established horizons. Perhaps the most important addition is the form doubtfully referred to Aucella. It is represented by one fairly good valve and a fragment of another which might belong to either $A$. piochi of the Knoxville or to $A$. erringtoni of the Mariposa as far as can be determined from the features preserved. Unfortunately there is no right valve in the collection, and the generic reference is not positive. If it is really an Aucella, the age of the beds is either Mariposa or Knoxville, more likely the former. The general character of the other forms is suggestive of the older faunas of the Taylorsville region, but it must be admitted that there is no definite evidence of this.

The following list mentions the forms distinguished:

Ostrea sp.

Pecten. Two or three species.

Aucella? Imperfect specimens with the form of $A$. piochi or A. erringtoni.

Modiola sp.

Trigonia sp.

Cardium? sp. This is an abundant species that in a previous report was thought to be an aviculoid shell and doubtfully referred to Eumicrotis. The specimens of the present collection are somewhat better preserved, but the generic reference is still doubtful.

Belemnites sp. Several fragments.

\section{SUPPOSED MARIPOSA IN NEVADA.}

In western Nevada, according to King, ${ }^{a}$ a thickness of probably 4,000 feet of fine-grained argillaceous slates overlies the Jurassic limestone, and he says: "It is quite clear that these upper Jurassic slates are to be correlated with the similar rocks in California." Later researches have not yet thrown definite light upon the above correlation except that it now seems possible and perhaps probable that the slates of western Nevada may be equivalent, at least in part, to the Foreman beds of the Taylorsville region.

\section{TERTIARY.}

\section{AURIFEROUS GRAVELS.}

GENERAL STATEMENT.

The auriferous gravels outlined in the maps of the Taylorsville region are deposits of an ancient system of drainage, in Tertiary time, very unlike that of the same region to-day. The principal ancient stream, Jura River, had its source in the high Sierra summits, possibly west of the main crest, in the neighborhood of English Moun- 
tain, as shown in Pl. I, and flowed in general a little vest of north, by the Cascade mine, across the Downieville quadrangle and the Mount Jura divide, in the Taylorsville region, to the northern end of the Sierra Nevada, beyond Indian Valley, where it entered a larger body of water and formed the main mass of auriferous gravel, one of the most extensive deposits of its kind in California.

AURIFEROUS GRAVELS OF JURA RIVER CHANNEL.

Mount Jura divide.-The divide extending northeast from Mount Jura toward Kettle Rock has four areas of auriferous gravels, as shown in Pl. III, and preserves a cross section of the ancient valley once occupied by Jura River. The two largest of these masses have been mined at Taylor and Hull diggings and range in altitude from 5,300 to 5,600 feet. One of the smaller areas near the west side extends down to 5,100 feet, but this may be due in part to a landslide; the other lies at an altitude of 6,000 feet on the east side of the valley. In all probability these four areas were once connected, forming a continuous mass for approximately 5 miles along the divide.

Taylor diggings.-Taylor diggings, a mile northeast of the summit of Mount Jura, were operated years ago by a ditch from Taylor Lake, near Kettle Rock, and expose about 100 feet of gravel, at the bottom of which lies a bed of impure lignitic coal about 5 feet in thickness. Prospect tunnels have been run into this bed for a short distance to the west and south and about a ton of coaly material removed and tried for blacksmithing. The coaly material lies on Jurassic bed rock and is overlain by gravel, varying in size, but throughout a thickness of 100 feet rarely as much as 6 inches in diameter. The pebbles are chiefly metarhyolite, like the rock so well exposed along the eastern slope of Grizzly Mountains. The remaining pebbles are for the most part granite and basic igneous rocks, some of which are rich in pyroxene.

Hull diggings.-On the Lucky $\mathrm{S}$ road is a flat-topped mass of gravel capping the divide and main spur for over 3 miles. At the head of the north fork of Hosselkus Creek, Hull diggings expose about 100 feet of gravel, in the upper portion of which there are 15 feet of fine sand and gravel. The coarser gravel above and below contains pebbles rarely as large as a man's head. Toward the bottom there is much sand and bowlders of metahornblende-andesite porphyry unlike the meta-andesite bed rock, and some of the bowlders are 5 feet in diameter. Whether these bowlders occur sporadically in the sand or form a distinct layer could not be determined for lack of definite exposure. No bowlders occur in the well-exposed upper half of the deposits. Similar bowlders occur along the borders of the exposed areas where the gravel has been removed and has brought 
the bowlders to the surface. Farther southwest toward Taylor diggings a number of granite bowlders occur with the others, and it is evident that all came out of the gravel deposit.

The small mass of gravel on the Lucky S road, $2 \frac{1}{2}$ miles east of Hull diggings, is fine and contains many dark pebbles like hornfels. No bowlders were observed. The gravel, although well rounded, differs considerably in composition from that farther west, and it is possible that this deposit belongs to a side stream.

The gravels of the Mount Jura divide contain no pebbles of the Tertiary lavas which lie to the east. and northeast. Many pebbles of igneous rocks are present, but they are all of types that belong to the pre-Tertiary bed-rock series.

Peale diggings.-Following up the Jura River deposits south from Taylor and Hull diggings, we come to three flat-topped masses of gravel at an elevation of from 5,500 to 5,800 feet capping the divide between Wards Creek and Little Grizzly Creek, southwest of Genesee Valley. Peale diggings in these masses expose about 100 feet of gravel, in which pebbles of old rhyolite or quartzite like those of Grizzly Mountains are most abundant. There are some of darker igneous rock and a few of granite. Pebbles 6 to 10 inches in diameter are common, but bowlders as large as 2 feet in diameter are rare.

In the gravel bars of the present streams of the Taylorsville region, and in fact along all streams with fairly strong grade, it may be observed that the somewhat flattened pebbles instead of lying horizontal are generally inclined so that they lean downstream, and, like shingles of a roof, overlap in that. direction. Their upper surfaces slope upstream. This is their position of greatest stability against stream erosion and shows the direction of flow in the stream making the deposits.

At the Peale diggings most of the pebbles are approximately spherical, but a few are somewhat flattened and generally slope southward, showing that the stream came from that direction. The fact that the pebbles are largely of quartz porphyry, like that of Grizzly Mountains, from which the stream came, points to the same conclusion.

Cascade mine to Mohawk Valley.-The facts of the country south of the fortieth parallel are drawn largely from the publications of Turner and Lindgren. In the Downieville folio, page 4, Turner has traced the deposits of the ancient stream we are following from 2 miles southeast of Tower Rock southward, by way of the Cascade mine, Lava Peak, and Mohawk Valley, to Haskell Peak and beyond in the crest of the main divide between Mohawk Creek of Feather River and North Fork of Yuba River.

At the Cascade mine sandy layers are interstratified with gravel, and the total thickness of the deposits is 325 feet, at an elevation of 
about 6,000 feet. There are large granite bowlders in the gravel and the bed rock belongs to the auriferous slate series, cut by numerous dikes. The occurrence of granite bowlders to the north of their source, though but a short distance, Turner thinks may be regarded as evidence that the stream flowed to the north. The Cascade mine gravel lies on the edge of a great mass of andesitic breccia, beneath which it extends southward, to reappear on the slopes of Little Long Valley Creek at an altitude ranging from 6,000 down to 5,000 feet; and a little farther south at Cedar Creek, on the border of Mohawk Valley, the gravels appear to reach a somewhat lower level.

From Peale diggings to Mohawk Valley the deposits "are similar in being made up of gravel and coarse sand with very little fine sediment," and Turner remarks, "this may be taken as evidence that the river bed had a higher grade than the river beds of the southwesterly system in the western half of the Downieville quadrangle."

1long Haskell Peak escarpment.-South of Mohawk Valley the ancient gravels of Jura River appear in patches at an altitude of about 7,000 feet on the edge of a plateau-like ridge running northwest of Haskell Peak. Here the gravels are overlain by rhyolite, which is in turn locally overlain by andesite. The gravels contain a great variety of pebbles. Turner mentions "contact metamorphic schist, granite porphyry, altered glassy andesite (?) showing flow structure, an altered holocrystalline basalt, a variegated breccia (red and green) made up of microlitic fragments of lava, and a red fine-grained tuff." The last two are very similar to some of the tuffs of the Milton formation and he suggests that they probably came from Chips Hill, farther south, where the Milton formation lies directly beneath the gravel.

Chips diggings, reversed drainage.-At Chips Hill, 3 miles northeast of Sierra City, where the gravel has been extensively mined, it is overlain by rhyolite, and this in turn is covered by andesitic breccia. The bed rock is at an elevation of 6,500 feet, or about 500 feet lower than the gravel of Haskell Peak, with which Turner thinks it was once connected by a stream flowing north. He considers that a great displacement has taken place between Mohawk Valley and Haskell Peak, with differential change of level on the western side of the fault that reversed the drainage from north to south.

Three miles southeast of Sierra City, at an elevation of 6,500 feet, is a trace of river gravel on the edge of a flow of rhyolite that has come down from the crest southeast of English Mountain, which Turner regards as the head of the ancient gravel stream that flowed north by Mount Jura.

Question as to head of Jura River.-The course of the stream beyond Haskell Peak is a matter of doubt. As given above it enters the 
Downieville quadrangle near Milton, coming from the Colfax quadrangle, where Lindgren has studied the ancient streams in detail. $\mathrm{He}$ refers to a strongly marked depression beginning in the vicinity of Fordyce dam and extending northwesterly in the direction of the Milton-Meadow Lake channel, which he describes, and he concludes from the bed-rock elevations that it turned westward in the vicinity of Milton, where it was joined by "a tributary coming down from the vicinity of Haskell Peak," and remarks, ${ }^{a}$ "the high bed-rock ridges near Haskell Peak, the northern side of which has been examined by Mr. H. W. Turner, preclude, except by assuming very large subsequent disturbances, any supposition that the channel could have flowed northward from Milton." It is evident that the difficulty in the way of accepting Turner's view as to the source of Jura River would be removed if it could be made to appear probable that the Milton region, including Chips Hill, had subsided with reference to Haskell Peak and reversed the slope. The argument in favor of this view to be drawn from the relation of the present divide to the main ridge will be considered presently. Attention will be given first to the light thrown on the question by the distribution of the gravels.

The large deposits of gravel at Haskell Peak give positive evidence of a good-sized stream. The gravel, composed, as Turner has shown, of a great variety of rocks, rests directly on granodiorite and must have been brought from some distance. At that time Haskell Peak did not exist. It is made of lavas all of which are younger than the auriferous gravels and overlie them, so that Haskell Peak can not be considered the source of the ancient gravel stream. Whatever the direction of flow of the gravel stream at Haskell Peak, except directly on the line of the crest, it must since have experienced a reversal of drainage slope on the approaching side. The definite knowledge of Jura River and its deposits from Mohawk Valley north demonstrates that it is not the north-slope drainage of Mount Haskell that has been reversed, and points to the south slope as the one reversed.

For 2 miles northwest of Haskell Peak the ancient gravel stream bed follows the divide to a point where the crest is offset to the west. Here the gravel ends. Leaving the divide and following the stream course northwest no gravel is seen for nearly 10 miles, until it appears on Cedar Creek beyond Mohawk Valley. From that point to Mount Jura divide the channel is easily traced.

If now we return to Haskell Peak and try to follow the stream course along the crest to the southeast no trace of it appears, although the crest is bare and well fitted with local lava capping which might reasonably be expected to preserve the gravel in place. It appears most probable, from the absence of gravel on the divide, that the channel lay farther west, more nearly in the direction of the general course 
of the stream. The known gravel masses which lie beyond Haskell Peak most nearly in the general course of the ancient stream are those of Chips Hill in line with that on the divide north of Milton, suggesting their source for the Haskell Peak gravels.

Drainage suggested by rhyolite flow.-There is a suggestion of continuous drainage from Meadow Lake to Haskell Peak in the distribution of the rhyolite flows which followed the watercourses, but the suggestion may be misleading, for the rhyolite appears to have come from several sources. The flow from near Meadow Lake, outlined by Lindgren, may have continued as far northwest as Chips Hill, but the large mass farther north, as pointed out by Turner, probably originated in Haskell Peak.

If the drainage at the time of the rhyolite eruption was westward in the vicinity of Milton, and the supply of lava sufficiently large, a westward turn of the rhyolite stream would be expected. Such a turn is suggested in Findley Peak, and others may have been washed away. It is possible, too, that the rhyolite north of Middle Fork, of the Yuba came from Haskell Peak. Whatever may have been the course of drainage during the gravel period or at the time of the effusion of the rhyolite, there can be no question that the streams of andesite from the eastward followed essentially the present system of drainage through a gap in the line of the main crest represented by Sierra Buttes.

Suggestion of double crest.-It is important to note that the topography of the region is exceptional in that there are two crests. The main crest between Mount Elwell and Castle Peak passes through Sierra Buttes, Findley Peak, and English Mountain to Meadow Lake, but this crest is not the present divide. The divide curves eastward through Haskell Peak and Webber Peak to near Meadow Lake, as if following the summit of what may be a small fault block east of the main crest between Sierra Buttes and Sierra Valley.

Fan-shaped drainage of the Milton region.--The drainage of the area in question is peculiar in that it is open fan-shaped. Both North Fork and Middle Fork of Yuba River head in this region. Their head branches converge toward Milton, where the two master streams turn west and within 3 miles of each other cut across the line of the old crest south of Sierra Buttes and then diverge down the western slope of the range. The peculiar constriction of these stream courses near their head can not be due to the relatively hard rocks of Sierra Buttes, for such rocks do not appear on the Middle Fork.

Present divide.-The highest points of the Haskell Peak divide are chiefly of volcanic rocks, which are later than the gravels, while the main ridge about Sierra Buttes is made entirely of bed-rock series. It is possible that during the gravel period the main ridge was the divide 50007-Bull. 353-08-5 
giving kirth to the drainage as outlined by Turner, but at the close of the gravel period, when the Mohawk Valley and Sierra Valley region sank 2,000 feet, the Milton region may also have gone down 500 feet and established a new divide through Haskell Peak.

MAIN MASS OF AURIFEROUS GRAVEL.

The main mass of auriferous gravel is spread in irregular patches over an area about 20 miles in length and 9 miles in breadth, with the greatest dimension parallel to the crest of the Sierra Nevada, on which it lies. Its western portion, in the Moonlight region, will be considered first and then, in order, the northern, eastern, and southern portions.

The Moonlight region.-Moonlight lies 12 miles north of Taylorsville, at the head of Surprise Creek. The divide east of Moonlight, ranging in altitude from 5,600 to 7,000 feet, is drained by the west fork of Lights Creek and affords the most extensive section of auriferous gravels in the region. The total thickness is over 1,000 feet. The lower 400 feet is chiefly sand and the upper 600 feet gravel or conglomerate, which is especially remarkable on account of its lithification.

The conglomerate is sometimes so firmly cemented that when the rock is broken the fracture passes through instead of around the pebbles. This feature gives to the conglomerate an aspect of greater age than the loose gravel possesses. Some of the conglomerate is fine, with pebbles of quartz of various colors and many pebbles of old andesitic rocks, like those of the county-line ridge, to the north. The paste is greenish and, as the microscope shows, is composed largely.of igneous material. The smooth round pebbles of the coarse conglomerate are occasionally faulted. Many pebbles are a foot in diameter, and rarely they are $2 \frac{1}{2}$ feet, but they average about an inch. A few beds of sand occur in the conglomerate, and when fine they generally contain fossil leaves, of which collections were made. The conglomerate and interbedded sandstone apparently strike N. $10^{\circ}$ E. and dip $20^{\circ} \mathrm{NW}$. The steep slope east of Moonlight is so covered with faulted landslide blocks that it is difficult to find the rock in place, but the whole succession of conglomeratic beds appears conformable and not less than 600 feet in thickness.

The sandstone beneath the gravel for 100 feet is fairly well cemented and some of it is light gray, like tuff, but the microscope shows it to be made up of angular particles of quartz and some plagioclase with much argillaceous matter and no definite volcanic fragments. Below this the material is softer and landslides abundant. Exposures are few, and the sand of the lower portion of the deposit is arkose. The rocks, too, beneath the sand are largely disintegrated. Traces of leaves occur at many places, and the upper part where firmly cemented makes a rough ridge with steep cliff face to the east. The thick mass of the Moonlight region extends north across the divide to the head of Wil- 
lards Creek, where it expands into a much larger area, to be noted presently.

South end of Mountain Meadows.-At the southeast head of Mountain Meadows is a body of well-rounded gravel which covers the broad - and low divide between Mountain Meadows and Cooks Canyon. The gravel is not cemented, lies flat as deposited, and looks younger than that of the conglomerate east of Moonlight. It represents the unmodified bed of the western branch of the ancient Jura River. The gravel is not very coarse and bowlders are not common. Where mined, it is underlain by sand, and the whole mass is not over 20 feet in thickness.

$\rightarrow \quad$ In one mine only 5 feet of gravel was exposed overlying 21 feet of gray and reddish sand. Upon both sides it is limited by ancient igneous rocks. To the southeast it has been washed away, and thus its connection with Moonlight has been severed. To the northwest it passes beneath the alluvium of Mountain Meadows and does not reappear until the northern end of the meadows is reached at the Narrows. The - slope east of Mountain Meadows is generally free from gravel and is formed of ancient volcanics capped here and there by later flows of lava which have not been mapped.

North end of Mountain Meadows.-The Red Bluff-Susanville road is on gravel from the north end of Mountain Meadows across the divide to near Stocktons, a distance of about 10 miles. West of the summit the streams (dry in summer) which enter the meadows from the southeast at Nanney and Browns afford sections of about 500 feet of gravel capped on the crest by lava and tuff. The gravel has alarge proportion of siliceous pebbles. Many are of black chert, with others of old sandstone and conglomerate and a few of older igneous rocks. In this regard as well as in their general lack of cementation they are strongly contrasted with the deposits of older gravel on the slope east of Moonlight. These gravels south of Browns, so clearly capped by lava and tuff, are underlain by sand, which gives rise to many landslides, some of whose basins still contain swamps or ponds. This pitted surface has the aspect of a moraine, but contains no bowlders, and passes into protected portions which are not only free from landslides, but pass beneath the capping layer of andesite tuff. Half a mile southeast of Nanney was found a smooth round pebble of fossiliferous sandstone like that of Hinchman Ravine on Mount Jura. Near the summit of the gravel pebbles of modern lava become abundant, but no definite horizon was observed at which the pebbles of modern lavas begin to appear.

Generally the gravel about Mountain Meadows is not cemented; but a rather striking exception to the rule occurs one-fourth milenorthwest of Browns, where the cemented sand and gravel rich in quartz forms a low divide and is overlain by loose gravel, which is finally capped to the northwest by volcanics. It seems probable that the 
cementation of the gravel in this case may be due to the intrusion of the andesite which forms the bluff opposite Nanney.

Willards Creek district.-On the slopes of Willards Creek the auriferous gravels are exposed to a thickness of over 500 feet, but the sediments are not so firmly cemented as those east of Moonlight and at the head of Gold Run. The gravels exposed contain numerous pebbles of fresh lava with those of black chert, sandstone, and other siliceous material, which appear to have been derived from earlier gravels by erosion. One of the pebbles of gray sandstone contained a characteristic Rhynchonella of the Mormon formation of Mount Jura near Taylorsville, and indicates clearly its source. The following section was observed $1 \frac{1}{2}$ miles southeast of the road summit:

Section near road summit, Willards Creek district.

Feet.

Andesitic volcanic breccia.................................... 20

Gravel containing many lava pebbles with older ones of chert, etc.......... 75

Sandstone with a little fine conglomerate and light-colored beds of fine rhyolitic

tuff ..................................................... 90

No satisfactory exposure was obtained of the material underlying the rhyolitic tuff.

The tuff is composed largely of light-brown amorphous dust, splinters of clear glass with fragments of clear glass pumice, and angular grains of quartz, feldspar, augite, and hornblende. It is decidedly cross-bedded and appears to dip gently to the northeast.

A chemical analysis of this rhyolitic tuff (p. 92) shows that it is apparently identical with the rhyolitic tuff which caps the earlier gravels at various places on the western slope of the Sierra Nevada. Unfortunately, on Willards Creek the part of the section below the rhyolitic tuff was not found exposed.

Head of Gold Run.-Gravel occurs along the Taylorsville road most of the way down Gold Run. Near its head west of the road where firmly cemented the conglomerate has a thickness of over 350 feet, dips gently to the northeast, and forms prominent cliffs. At this point the conglomerate varies in the size of the pebbles, but is rarely coarse. Some of the pebbles are crushed and faulted in a way to indicate great strain. These effects were observed only in the conglomerate near the crest of the range, from which considerable material may have been removed by erosion. Many of the pebbles are of old volcanic rocks like those noted in the gravels east of Moonlight. The interbedded lenses of fine sediment occasionally contain fossil leaves, of which an excellent series of specimens were collected by James Storrs in 1904. They were obtained about three-fourths of a mile northwest of the road summit and 350 feet below it, on a branch of the west fork of Gold Run. Dikelike bodies of hornblende andes- 
ite cut the conglomerate gravels at this point, and their intrusion may have had something to do with the induration of the gravel mass.

Diamond Mountain gravel.-On the Sierra crest, a few miles southeast of the Lights Canyon road summit, there are two high points, both composed of andesitic breccia. The west one is commonly known as Red Mountain on account of the colored tuff, while the other, about a mile to the northeast, is called Diamond Mountain. Between them is a ridge of gravel which is overlain by the volcanic breccias of the two peaks. Near Red Mountain the gravel of this ridge is composed largely of quartz, chert, and old sedimentary as well as igneous rocks. Farther east as the ridge rises lava pebbles come in, and near the top the pebbles are almost wholly of lava. The contrast between the earlier quartzose gravel and the later directly overlying gravel of lava fragments is striking. The gravel contains occasional bowlders, some of which are 12 feet in diameter and entirely out of accord with the associated well-rounded gravel. One bowlder and several large pebbles were found with striæ, but no definite glacial moraines were distinguished.

$\Sigma$ sutheast of Diamond Mountain a prominent ridge of gravel forms the crest of the Sierra for several miles at an altitude of over 7,000 feet, overlooking the bold escarpment facing Honey Lake Valley. The gravel of this prominent crest ridge is about 300 feet in thickness and rests on the granite which outcrops on the eastern slope. The gravel is coarse and chiefly of andesitic fragments on the surface, but near the bottom is finer, though the lower half of the mass contains most of the granite bowlders strewn on the eastern slopes. The ridge is separated from Diamond Mountain by a gap from which the gravel has been removed. A small pond occurs in the gap, and a flow of basalt with flow structure rising to the northeast forms a cliff facing in the same way as if the lava flow came from that direction. Similar basalt hangs on the granite slope a mile to the southeast. A small gravel scarp near the pond suggests faulting.

Gravel has been mined to a very limited extent along the eastern base of the Sierra, a short distance south of Gold Run, 4 miles from Susanville, but no large body of gravel is exposed at that point. If it ever extended so far east, it has probably been covered by the later lavas and lake deposits of that region.

Diamond Mountain shore terraces.-Shore terraces are well developed about Diamond Mountain, as though it were an insular mass against which the waves beat and carved out a shore line. As shown in fig. 9, Diamond Mountain has five spurs running in various directions. The summit of the mountain is (1) andesitic breccia, about 300 feet in thickness. On each spur the breccia is limited by a more or less clearly defined shore cliff, beyond which is a mass of (2) gravel composed almost wholly of well-rounded lava fragments. 
Beyond the lava gravel (2) on most of the spurs at a lower level comes (3) the gravel in which pebbles of Tertiary lavas are rare or absent and pebbles of quartzose rocks are most abundant. Their general relations in a vertical section are shown in fig. 10, where the numbers have the same significance. The total thickness of the gravel is less than 300 feet. Granite bowlders appear to be most abundant

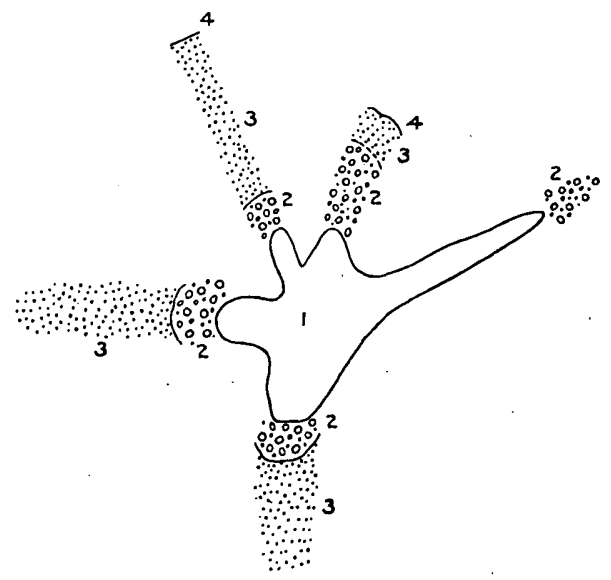

FIG.9.-Sketch plan of Diamond Mountain, showing shore terraces on spurs. 1, Andesitic breccia forming summit; 2, gravel of lava pebbles on shore terraces on spurs;

3 , gravel rich in quartz pebbles; 4 , granodiorite. on the lower half of the gravel. Farther southeast along the crest under the thick mass of basalt flows, forming Thompson. Peak, there is no gravel separating it from the granitic rock. On the contact the basalt includes a residual bowlder of diorite, showing that the basalt flowed over a surface long exposed to disintegration.

Lone Rock and Kettle Rock regions.-Southwest of Diamond Mountain, in the flat country drained by the headwaters of Indian Creek, the gravels are widely distributed in a heavy body, although much of it has been removed by erosion. The east border laps over upon the granite without any lava capping and extends south, sending a branch to the forks of Indian Creek, where it ends at an elevation of about 1,000 feet below the main crest of the gravel ridge. West

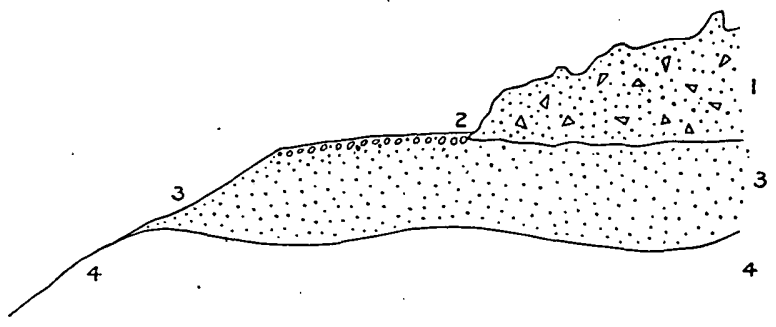

FrG. 10.-Generalized section of spur of Diamond Mountain. 1, Andesitic breccia; 2, gravel of lava pebbles; 3 , gravels rich in quartz pebbles and sand below; 4 , granodiorite.

of Lone Rock, on the branches of the south fork of Lights Creek, the gravel was not cemented and has been largely removed, leaving on the lower slopes but a thin coating on the arkose sands, which contain occasional well-rounded quartz pebbles to show that they are not residual but recomposed. Farther south it caps the broad divide rising toward Kettle Rock, and above the Lucky.S mine reaches 
an altitude of over 7,000 feet. Several hundred feet of gravel occur here. The lower part is fine, with many pebbles of quartz and siliceous rocks, and the upper part, associated with the volcanic breccia, is composed chiefly of andesitic fragments. The earlier gravels near the Lucky $\mathrm{S}$ mine were once connected with those of a few miles southward on the Mount Jura divide, but the later gravels of lava pebbles. present above the Lucky $\mathrm{S}$ mine appear to be absent on the Mount Jura divide.

ISOLATED MASSES OF GRAVELS NORTHEAST OF MOHAWK VALLEY.

This country forms the eastern slope of Jura River and is somewhat remarkable for the paucity of its gravels. The principal body found in this region is near Mapes, on Squaw Creek, 5 miles northeast of Chase's, where a knoll on the meadow border is made up of cobblestones and pebbles of granite and dark shaly rock, with many of lava. Though.of small extent it is a veritable washed gravel, and must once have underlain an adjacent mass of lava several hundred feet in thickness. Whether the gravel rests directly on the granodiorite or is separated from it by a thin sheet of volcanic rocks was not definitely determined.

Traces of gravel and bowlders were found on the west side of the crest opposite Milford, but similar pebbles occur in the associated tuff, and they may have been liberated by weathering. By a small area of altered rocks inclosed in the granodiorite, 3 miles southwest of Clark's dairy, there is a small mass of quartz gravel locally developed, which may represent a small stream extending to the margin of the delta gravel only a few miles to the northwest.

A few pebbles of quartzose rocks were found near Chase's on Red Clover Creek, but no. definite body of gravel was seen in place. However, it is not only possible but probable that a stream passed near there, for on the north slope of Mount Ingalls is a mass of well-rounded coarse gravel of lava fragments deposited during the volcanic period, but most likely representing a descendant of a stream of the prevolcanic period.

The contact of the gently rolling platform of granodiorite and the overlying sheet of volcanic rocks was examined at many points about the heads of Squaw and Last Chance creeks without finding a trace of gravel, and it is certain that the great sheet of estuarine gravel, which at Diamond Mountain lies between the sheet of volcanic rocks and the granodiorite, does not extend south of the latitude of Kettle Rock.

Along the fortieth parallel east of Red Clover Creek granodiorite forms a broad platform gently inclined to the northwest. It is covered throughout most of the area by a sheet of volcanic rocks whose thickness is only a few hundred feet. The thin cover it makes for 
the granodiorite is especially well exposed along the eastern escarpment, where it appears only on the crest. The escarpment is of granodiorite.

\section{CLASSIFICATION OF THE AURIFEROUS GRAVELS.}

The early investigations of the Geological Survey of California under J. D. Whitney proved the fluviatile origin of the gravels, but it remained for the later workers, especially Ross E. Browne, H. W. Turner, and Waldemar Lindgren, to work out their classification. The latest expression on the subject is by Lindgren, ${ }^{a}$ who states that in the principal broad Neocene river valleys one may generally distinguish the following formations:
A. Antevolcanic deposits.... $\left\{\begin{array}{l}1 . \text { The deep gravels. } \\ 2 . \text { The bench gravels. }\end{array}\right.$
3. The rhyolitic tuffs.
B. Volcanic and intervolcanic 4 . The gravels of the rhyolitic period. deposits.
5. The gravels of the intervolcanic erosion period.
6. The andesitic tuffs and tuffaceous breccias.

For various reasons the gravel deposits where thickest, east of Moonlight and at the head of Willards Creek, are not worked, so that complete and detailed sections are nowhere available. The lower portion of the mass especially is affected by landslides, and outcrops are few. As a whole the deposits of the Taylorsville region included under the general term auriferous gravels may be considered under the following headings:

\section{EARLIER DEPOSITS (PREVOLCANIC).}

Arkose sands. - At every point where the bottom portion of the main mass is exposed it is found to be composed of sand, and the greater part, especially the lower, is often decidedly arkose, so much so that in some of the mines it was difficult to tell whether the material was simply disintegrated granodiorite in place or recomposed. In most cases careful search ultimately brought to light a few small but smooth round quartz pebbles to prove it arkose. Gravel beds in this portion are rare. In some cases carbonaceous clay beds, amounting even to impure coal, occur, but it is not certain that they underlie the main mass, though the sand is believed to underlie the whole with a variable thickness, and a local maximum of not less than 500 feet. Some of it is lithified, forming sandstone.

When we turn to the river channel some distance above where it joins the main deposits, as, for example, at Peale diggings and farther up the stream, the fine beds at the bottom have disappeared. It is to be expected, of course, that the main mass in general is older than that in the channel, which is ever moving downstream to join the delta. 
The prevolcanic gravels.-These gravels usually contain more or less pebbles of white quartz with others prevailingly quartzose, and all are derived from the bed-rock series, among which there are many igneous rocks, but no Tertiary lavas. The material ranges in size from occasional sand streaks to scattered bowlders up to 12 feet through, but the greater number of the pebbles are from 1 to 4 inches in diameter. Locally they are cemented so as to form conglomerate. The gravels of the Jura River bed throughout its whole course, as well as the bulk of the gravels of the delta, belong to this horizon. It has a maximum thickness of over 500 feet, and near its base contains fossil leaves.

It has not been found possible at any point I have had an opportunity to examine along the course of Jura River to distinguish the deep gravels and the bench gravels described by Lindgren. The great bulk of the stream gravels in the broad channel are undoubtedly bench gravels, but the presence of the deep gravels could not be clearly demonstrated. More extensive mining may bring them to light. However this may be, the equivalents of both deep gravels and bench gravels most likely occur in the main mass, but have not yet been distinguished.

LATER DEPOSITS (INTERVOLCANIC).

Rhyolitic tuff.-In the region of Willards Creek rhyolitic tuff was found interbedded with sandstone between masses of conglomerate, and it belongs in the succession of gravels before the eruption of the volcanic breccia. There are several beds of tuff grading into sandstone which are very similar to the rhyolitic tuffs which Lindgren and Turner have described as overlying the bench gravels in the Sierra Nevada south of the Taylorsville region. Rhyolite flows occur at Haskell Peak and beyond, overlying the gravels to the head of Jura River, and are themselves overlain by flows of andesite breccia, but both kinds of flows are generally absent from the ancient river channel north of the fortieth parallel until the main mass is reached in the vicinity of the present crest. Chemical analyses of the rhyolite tuffs farther south are not available for comparison, but Lindgren, who has kindly examined the slides and specimens from Willards Creek, recognizes them as being practically identical with the rhyolite tuff to which he refers.

Intervolcanic gravels.-Overlying the rhyolitic tuff and sandstone on Willards Creek is a mass of gravel containing a considerable proportion of lava pebbles, and these increase in amount upward through a thickness of about 75 feet. These were found at only one place, and were not studied in great detail at the time, but they appear to lie conformably between the andesitic breccia and rhyolitic tuff and find their equivalents most likely in those of the rhyolitic period and intervolcanic-erosion period of Lindgren. 
Volcanic flows, chiefly andesitic breccia.-This material is mainly of hornblende and hypersthene andesite, often in the form of breccia, such as filled the broad valleys and covered the rhyolite flows and auriferous gravels at many points. Their source in the Taylorsville region is fairly well marked at Red Mountain, near Diamond Mountain, and a few miles farther northwest on the crest, and by their extrusion over the submerged end of the Sierra Nevada the bottom became very irregular. As eruptions progressed the water became more shallow, with islands along the summit.

Shore gravel.-The islands along the crest are bordered by beach platforms paved with coarse gravel and cobblestones of andesite, with a few of basalt derived directly from the adjacent shore. Their lower portions locally join the intervolcanic gravels, but their relations could not be fully determined. The prevolcanic gravels at Moonlight and the head of Willards Creek, as already pointed out, have a decided dip of from $15^{\circ}$ to $20^{\circ}$, which appears to indicate tilting after deposition; but as clearly bedded andesitic tuff associated with the volcanic breccia shows the same inclination, it appears that the tilting took place in the final movement after all the gravels were deposited, possibly with essential conformability throughout.

IONE FORMATION.

The Ione formation, made up chiefly of sand and gravels, lies along the western base of the Sierra Nevada in the Sacramento Valley, where Lindgren ${ }^{a}$ has found that it contains Miocene shells, and with Turner $^{b}$ has shown that it was deposited synchronously with the older auriferous gravels. The Ione formation is extensively developed in the eastern part of Shasta County, from Cow Creek to Kosk Creek, beyond the great bend of Pit River, and contains fossil leaves and local traces of coal. The strata dip easterly beneath the great mass of Tertiary lavas about Lassen Peak, and are believed to represent the same geologic horizon, and possibly are connected with the great mass of auriferous gravels which disappear beneath the same lavats at the north end of Mountain Meadows. This correlation is practically demonstrated by a comparison of their floras.

FLORA OF THE PREVOLCANIC GRAVELS.

The only fossils found were in the earlier auriferous gravels, and collections were made at two localities-one near the eastern end of Moonlight on the slope toward the west fork of Lights Creek, at an elevation of about 6,000 feet, the other three-fourths of a mile north of the road summit between Taylorsville and Susanville, at an elevation of 6,000 feet on the slope of Gold Run, and about $7 \frac{1}{2}$ miles southwest of Susanville. Fossils were collected years ago from the same 
mass of gravel ${ }^{a}$ at the head of Mountain Meadows and also threefourths of a mile north of the Lights Canyon road summit. Plants from both these localities have been tabulated with the later collections for comparison with those from the auriferous gravels of the Sierra Nevada south of the Taylorsville region, as well as those of the Ione formation on Little Cow Creek and Kosk Creek of Shasta County. The earlier collections examined by Professor Lesquereux have been studied by Knowlton, whose determinations are given in the following table, which contains all the forms thus far identified in the Taylorsville region and in the Ione of Shasta County:

\section{Tertiary fossils from Taylorsville region and vicinity.}

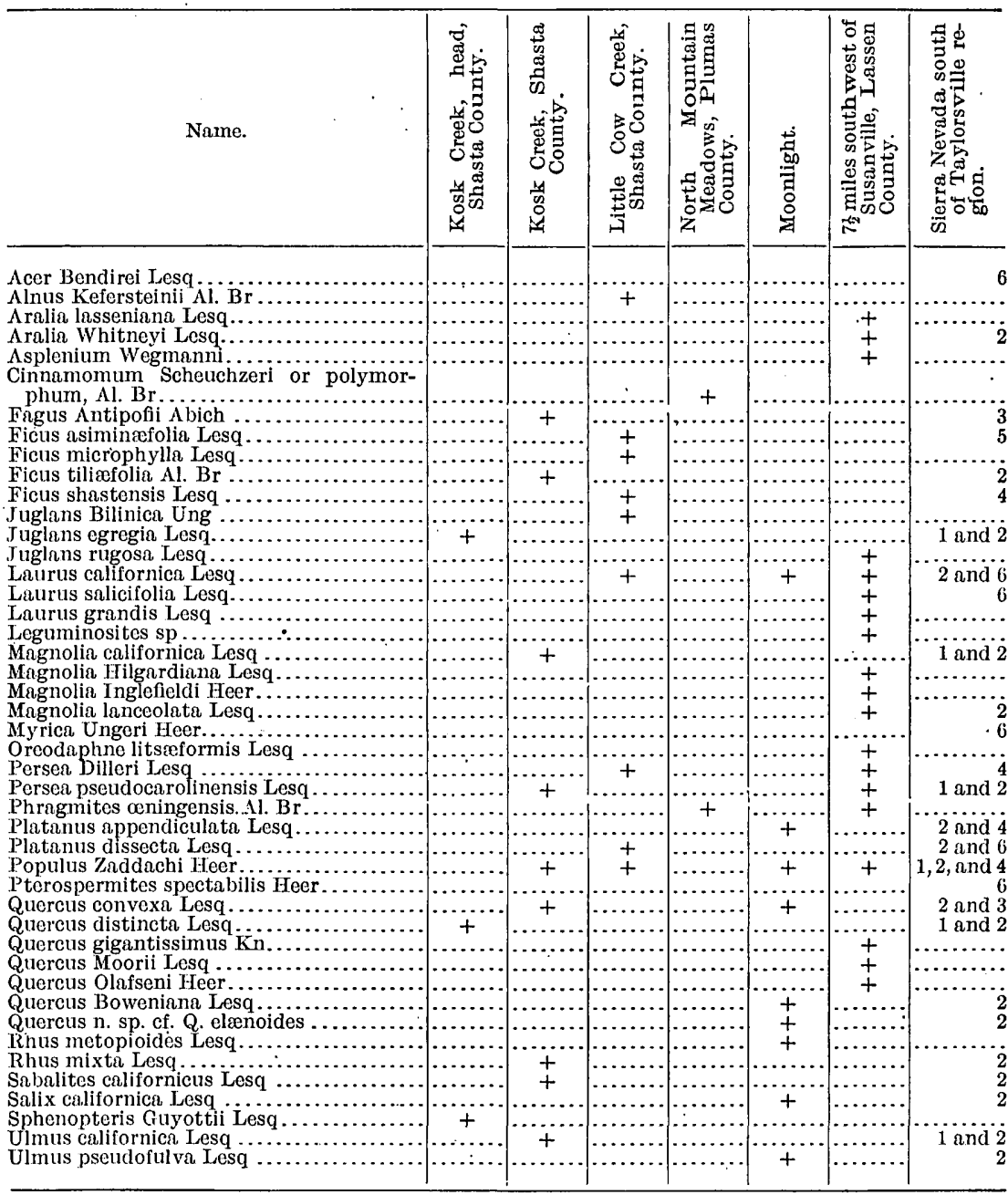


In the final column of the table the particular locality at which the species has been found is indicated by figures. $1=$ Chalk Bluff, $2=$ Independence Hill, $3=$ Table Mountain, $4=$ Volcanic Hill, $5=$ Rock Corral, and $6=$ Monte Cristo mine, Spanish Peak. The fossils from Little Cow Creek and Kosk Creek, Ione formation, are from essentially the same mass. The same is true also of the three localities of the Taylorsville region. For purposes of comparison, therefore, the localities noted in the table may be grouped under three heads; Ione of Shasta County, northern end of the Sierra Nevada, and western slope of the Sierra Nevada.

In the Ione of Shasta County 20 species have been identified, and of these 18 have been recognized in the earlier gravels of the western slope of the Sierra Nevada, leaving no room for doubt that the two formations are for the most part synchronous in origin.

Twenty-seven species have been identified in the gravels of the Taylorsville region, of which 13 occur in the gravels of the western slope of the range, a correspondence which is sufficiently marked to show that the gravels of the two regions are closely related in age.

\section{AGE OF THE PREVOLCANIC AURIFEROUS GRAVELS.}

GENERAL STATEMENT.

The age of the auriferous gravels of the Sierra Nevada in California is generally given as late Miocene or Pliocene and is based chiefly on fossil plants and a few animal forms.

In his report on the later collections of fossil plants from the gravels of the Taylorsville region and the earlier collections from the Ione of Shasta County, Knowlton says that they are typical of the auriferous gravels and nothing in the collection suggests an age as old as the Eocene. This statement does not apply to the earlier collection, determined by Lesquereux, which Knowlton regards as of greater age.

The auriferous-gravel period in all probability was a long one, and no considerable part of its flora has yet been connected directly with its contemporaneous marine fauna of the same region. On physiographic and stratigraphic grounds and the general relations of the Sierra Nevada to sedimentation, it has long been supposed by some geologists that the oldest auriferous gravels, the deep gravels of Lindgren, are probably Eocene, but the evidence assigned is problematical rather than positive.

The locality $7 \frac{1}{2}$ miles southwest of Susanville, as given in the foregoing table, is essentially the same as the one ${ }^{a}$ three-quarters of a mile north of where Light Canyon and the Susanville road cross the summit. The small lens of shale from which the plants were collected in 1886 was exhausted, but another shaly lens near by in the 
same conglomerate furnished the material collected by James Storrs in 1904. The lenses differ lithologically and the floras are different, but they are reported by Storrs to be in the same mass of conglomerate and therefore of essentially the same age. The earlier collection. was regarded by Lesquereux as Eocene. ${ }^{a}$

EOCENE FLORA OF SOUTHWEST OREGON.

While studying the Eocene deposits of the Roseburg, Coos Bay, and Riddles quadrangles in Oregon fossil leaves were found in the same strata with marine shells, affording an opportunity to definitely connect the land flora with its contemporaneous marine fauna.

The following list of 10 species embraces the Focene plants identified by F. H. Knowlton with more or less certainty from a number of localities within the area noted above:

Magnolia lanceolata Lesq.

Magnolia californica? Lesq.

Laurus californica? Lesq.

Sabalites californicus? Lesq.

Aralia Whitneyi Lesq.
Populus Zaddachi Heer.

Aralia angustiloba? Lesq.

Juglans californica? Lesq.

Ulmus californica Lesq.

Ficus tiliæfolia? Al. Braun.

Among the shells found with or near the fossil leaves Dr. W. H. Dall has recognized over 20 genera, and remarks: "The fossils are Eocene. They contain a number of interesting things, particularly the Orbitolites, which is usually characteristic of the Oligocene on the Atlantic coast and is now for the first time recognizcd from the Pacific coast."

The fossil leaves were found near the southeast border of the Eocene, where shells are not abundant, but a short distance farther northeast they become very abundant locally with such characteristic forms as Venericardia planicosta and Turritella uvasana, and there is no doubt concerning the Eocene age of the strata containing the fossil leaves.

Of the 10 species of plants identified 7 are somewhat in doubt, but 3, Magnolia lanceolata, Aralia Whitneyi, and Populus Zaddachi, are completely satisfactory. They all occur in the auriferous gravels of Independence Hill, on the western slope of the Sierra Nevada, as well as on the summit of the northern end of the range, $7 \frac{1}{2}$ miles southwest of Susanville. The last species occurs at many other localities, among which may be mentioned the Ione formation of Kosk Creek and Little Cow Creek of Shasta County and the auriferous gravels of Moonlight, Chalk Bluff, and Volcanic Hill.

Eight of the 10 species reported from the Eocene of Oregon occur, according to Lindgren, in the bench gravels of Independence Hill, in California. It seems probable, therefore, that not only the "deep gravels," but also the "bench gravels," both of which belong to the prevolcanic gravels, may be of Eocene age. ${ }^{b}$ 
TOPOGRAPHY OF THE AURIFEROUS-GRAVEL PERIOD.

The two divides.-The drainage of the Taylorsville region during the auriferous-gravel period clearly supports the view that the Sierra Nevada was then a conspicuous range of mountains. with two divides at the north end separated by a longitudinal valley draining to the north. The first or main crest represents the continuation of the great divide of the range northwest from Castle Peak by Sierra Buttes and Mount Elwell to Spanish Peak, and the second, as shown by Lindgren, lies farther east and extends north toward Honey Lake, forming, at least in part, the east front of the range. These two summit crests in a general way outlined the drainage basin of Jura River, which flowed north between them to the estuarine body of water that probably covered a large part of the Lassen Peak region and connected directly with an arm of the sea in the Sacramento Valley. The estuarine-covered portion of the Taylorsville region was apparently about sea level during the gravel period.

Altitude of the region.-The flora of the Taylorsville region during the gravel period is in strong contrast with that of the same region to-day, and supports the view drawn from the drainage that the northern end of the range during the deposition of the prevolcanic gravels was much lower than now. This statement is not intended to apply to the range south of the fortieth parallel for the streams headed in that direction, and it is evident that the range there had greater altitude. In that direction Lindgren has shown by a careful study of stream grades that since the gravel period the summit of the Sierra has been raised with reference to the Sacramento Valley so as to increase the slope to the southwest.

Jura River Valley.-Jura River headed in the main divide and flowed parallel to its base for many miles before turning more nearly north. West of the river the valley had a short, steep slope from the main crest, while on the east there was a long, gentle slope to a distant crest. The paucity of gravels on the slope east of the river may be taken as an indication of the smallness of the streams as compared with the main river with its well-marked gravel course.

Small masses of gravel containing pebbles of lava were found on Squaw Creek (Pl. II), near Mapes, 4 miles northeast of Chases, and traces occur also in RedCloverValley, with a larger mass, of lava pebbles only, south of Genesee Valley, but no definite evidence has yet been reported east of the bed of Jura River to indicate the former presence in that region of an important contemporaneous stream.

Drainage of Sierra Valley.-No definite connection has yet been traced between Jura. River and Sierra Valley, whose records of the auriferous-gravel period are concealed beneath a cover of volcanic rocks and lake beds. Lindgren has traced the sunken area or moat, as he appropriately calls it, of the Lake Tahoe region as far north as 
Sierra Valley and suggests ${ }^{a}$ that during the gravel period the drainage may have been north. So large an area would give rise to a large stream and important deposits would be expected to record its course. A suggestion of its existence may probably be found in the observation of Turner, ${ }^{b}$ who reports bowlders and pebbles of rhyolite in the auriferous gravels near Cedar Creek, at the north end of Mohawk Valley lake beds, and remarks "that a portion of this gravel is of later age than that of the Haskell Peak channel, which is capped with rhyolite."

Uplift in gravel period.-The lower portion of the gravel deposits of the main area in the Taylorsville region is sand and the upper portion gravel, often coarse and containing bowlders. This decided and general change in the character of the sediment delivered by Jura River must have resulted from an increase of grade within the prevolcanic-gravel period, a change which under the circumstances points for its origin to a rise in the main crest of the range about Haskell Peak or farther south.

\section{QUATERNARY.}

Gravels of Keddie Ridge.-Three miles directly east of Greenville, on the west slope of Keddie Ridge, at an altitude of 4,100 feet, is a considerable body of well-rounded gravel forming the flattish summit of a spur. The pebbles are chiefly of quartzite, gray, black, and rarely red flinty rocks with fragments of slate and granite, and a few are of andesitic lavas. A prospecting shaft has been sunk 20 feet in gravel and sand and shows the pebbles dipping easterly toward a gap in the Keddie Ridge through which the depositing stream may have passed. The deposit is about 50 feet thick, 200 yards wide, and nearly half a mile long in the direction of the general ocourse of the stream.

Gravels near Greenville.-On the valley border 1 mile northeast of Greenville there is a mass of gravel exposed along the road for over half a mile. It is associated with soft whitish material, which may be volcanic, and is overlain by a sheet of andesitic lava in which pyroxene is the characteristic mineral. The two masses of gravel just noted probably belong to the same stream, which seems to have flowed across the gap of Keddie Ridge from the region of the head of North Arm, and may represent an early diversion of Jura River. Whatever may have been its source the topography of its time was very different from that of to-day.

North Arm pothole.-An interesting pothole occurs on the southeast side of North Arm, near Mr. Thompson's, $1 \frac{1}{2}$ miles northeast of Taylorsville. The waterworn rock is the Thompson limestone about 100 feet above the level of the adjacent valley border. The pothole is $2 \frac{1}{2}$ feet 
in diameter and 3 feet deep and contains a lot of well-worn gravel at the bottom to testify in a very satisfactory manner to its origin. There is no stream near it now, and the only reasonable explanation apparent ascribes it to the North Arm stream fashioning the slopes of the valley at that level.

Shoo Fly gravel terraces.-On the right bank of Indian Creek below Shoo Fly there are terraces ranging from 300 to 600 or more feet above the stream. Most of these terraces have a capping of rhyolite or basalt, and some have traces of gravel, but no large body of gravel was observed anywhere except on the low benches near the present stream level. These gravels are evidently of late origin, were deposited by Indian Creek, and according to Lindgren are distinctly connected with the Pleistocene gravels of American Valley.

Glacial moraines.-Glacial phenomena in the Taylorsville region are very meager and confined to the eastern slope of Grizzly Mountains. The small ravine heading against the northern side of Tower Rock had sufficient gathering ground at an altitude of 7,500 feet to give rise to a glacier over a mile in length. Its morainal deposits are strewn over the slope from 6,000 down to nearly 4,500 feet, where there is a prominent terminal mass. Higher up a lateral embankment is well marked on the west side.

A short distance farther north is a small lake due to a small moraine dam. The Devils Punch Bowl is an excellent example of the same sort. Crystal Lake of Houghs Peak is another example, and probably also Taylor Lake, near Kettle Rock.

Valley alluvium.-Valley alluvium is the sediment which fills the valleys and makes the level surface of Indian Valley, North Arm, and Genesee Valley. It contains some gravel, especially where streams enter the valleys. Sand is more widely distributed, but silt is the most common material and makes an excellent rich soil for agriculture.

The depth of the valleys and the character of the material below is not known. No deep borings or wells have been made. It is apparent, however, from the occurrence of the Mounds, which are simply knolls on a spur from Keddie Ridge, that Indian Valley is deepest on the western side.

\section{IGNEOUS ROCKS.}

GENERAL ACCOUNT.

The igneous rocks of the Taylorsville region are the same as those of the Sierra Nevada south of the fortieth parallel, which have been described in detail by Turner, Lindgren, and Ransome in various folios and special papers. This renders an extended treatment of them at this place unnecessary.

The igneous rocks include representatives of both acidic and basic types, some intrusive but most of them effusive, and are scattered 
at intervals through geologic time from the early Silurian to the Quaternary. The Paleozoic and early Mesozoic igneous rocks of the Taylorsville region are chiefly lavas which have been much altered from their original condition. To indicate the change the altered forms are designated metarhyolite and meta-andesite.

The earliest eruptive recognized in the Taylorsville region is the metarhyolite at the base of the Silurian quartzite. It is a large mass having a probable thickness of over 1,000 feet. This was succeeded in Carboniferous time by extensive eruptions of meta-andesite of great thickness, separable into three subordinate masses, Taylor meta-andesite, Kettle meta-andesite, and Reeve meta-andesite, each of which is outlined on the geologic map.

During Jurassic time volcanoes were again active near Taylorsville and the Fant and Hull meta-andesites were erupted. A great change took place about the close of the Jurassic, and the intrusive rocks of that time are strongly contrasted with the earlier lavas. Instead of metarhyolites and meta-andesites we have holocrystalline granular rocks, such as granodiorite, serpentine, pyroxenite, and various rocks occurring in dikes. The Tertiary volcanics are of three types, rhyolite, andesite, and basalt.

PRE-SILURIAN.

METARHYOLITE (QUARTZ PORPHYRY).

General description.-This is a massive gray siliceous rock which generally contains phenocrysts of quartz or feldspar embedded in a uniformly fine, compact groundmass. In the most common form on the slope of Grizzly Mountains phenocrysts of feldspar are absent, and those of quartz often inconspicuous or absent, but elsewhere both are usually abundant. Flow lines are not generally present but are sometimes conspicuous: Part of the mass is distinctly fragmental, made up of angular pieces of metarhyolite cemented by material of essentially the same sort. On a weathered surface the fragments usually become much lighter than the true interstitial material and make the brecciated character of the rock conspicuous, and it appears to be a veritable flow breccia. In other portions there are occasional bright-red fragments of various shades and tints which give prominence to its structure. Some of the fragments are rounded, suggesting attrition, while others are amygdaloidal, as if originally vesicular, suggesting. volcanic ejection, though no positive fine volcanic tuff was discovered.

Much of the metarhyolite has a decided schistose structure, which is in some places approximately parallel to the lines of flowage. On the lower slope of Grizzly Mountains the structure is very well 50007-Bull. 353-08-6 
developed and dips to the southwest parallel to the flow lines and the general stratification of the mountains. That this structure is due to compression and consequent shearing is shown by the fact, seen under the microscope, that the grains of quartz are crushed and displaced along the same lines.

Occurrence.-The mass designated as metarhyolite is complex, being made up of surface flows, some of which are thoroughly brecciated, intermingled with much ejected fragmental material spread over the country before the deposition of the Grizzly formation.

Relation to adjacent rocks. - The relation of the metarhyolite to the Grizzly formation is of greatest importance and has already been considered in connection with the quartzite. The pebbles of metarhyolite in the overlying quartzite afford definite and conclusive evidence that the quartzite was deposited upon the metarhyolite. The original surface of the siliceous lava was probably very rough and irregular, and these features have been intensified by deformation. On the lower slope of Grizzly Mountains opposite Huntington the ancient rhyolite has well-marked fluidal structure, in general parallel to the surface on which the quartzite was laid down and subsequently folded.

After determining the relation of the metarhyolite to the Silurian quartzite it is easier to understand its relation to sediments of later age. The Taylorsville formation, like the Grizzly, is folded or faulted into the metarhyolite, but in the case of the Arlington and later formations the sediments overlie the metarhyolite with evidences of less subsequent disturbance.

Distribution.-Metarhyolite is especially wel developed on the eastern slope of Grizzly Mountains. To the southeast it extends as a narrow belt for 11 miles into the Downieville region, where it has been recognized by Turner as made up of volcanic flows. To the north and northwest from Grizzly Mountains its area widens so as to form Keddie Ridge and the hills between Crescent Mills and Greenville and beyond, where it is covered by the later formations. It is possible that the igneous rock of this large area is not all of the same age. A small part of it may belong to the rhyolite erupted at the close of the Jurassic, and occurring as dikes in the earlier form, but the close similarity between the two rocks rendered it impracticable to separate them in all cases.

\section{CARBONIFEROUS.}

TAYLOR META-ANDESITE.

General description.-This rock is decidedly green and is generally designated greenstone by the miners. Where not too much altered it is porphyritic with numerous crystals of augite and occasionally 
feldspar, but in most cases the porphyritic structure has been obscured in the development of an imperfect cleavage.

Much of the rock has a decidedly fragmental structure, which is most plainly visible on a weathered surface. The fragments in some places are clearly vesicular and show that the fragmental material is really tuffaceous and represents explosive volcanic action, but it is rarely if ever a coarse agglomerate. In other cases, however, vesicular fragments are few or absent and the rock passes into a fine conglomerate. The matrix, like that of the tuff and the altered groundmass inclosing the phenocrysts of augite, is composed in large measure of secondary hornblende, chlorite, epidote, and quartz. The Taylor meta-augite andesite generally has an imperfectly developed slaty structure and is often traversed by quartz veins, many of which follow the lines of cleavage. Occasionally the rock is full of quartz amygdules, which stand out on the weathered surfaces, giving the rock the aspect of a quartz porphyry.

The phenocrysts of augite are rarely complete crystals. Some of them show one or more crystallographic boundaries, but for the most part they are fragments of crystals irregular in outline. Many of them have traces of a lighter colored fringe of enlargement. Phenocrysts of plagioclase are not common and the groundmass is generally so altered as to be completely replaced by epidote, chlorite, hornblende, and quartz, but where preserved it is made up of minute elongated crystals of feldspar arranged in streams. No definite trace of diabasic structure was found.

Occurrence.-Taylor meta-augite andesite occurs in irregular sheets which represent lava flows from ancient volcanic vents intermingled with clastic material blown from the same craters. One of the best localities to observe the relations is about Taylor Rock, where the tuffaceous portion is well exposed. The mass, as already noted, generally has more or less prominent cleavage planes which strike northwest and southeast, parallel to the general strike of the formation, and dip to the southwest. Owing to deformation and alteration the position of the lava flows and tuffs. is difficult to determine, but generally they lie in sheets approximately parallel to the stratification of the sediments between which they outcrop. That this is their true position can be best determined in the canyon of Indian Creek, between Shoo Fly and Arlington Bridge, where the great mass of meta-augite andesite lava and tuff lies conformably between the Shoo Fly and Arlington beds and dips steeply to the southwest.

Distribution.-The same conclusion may be drawn from its general distribution northwest of Houghs Peak, where for over 20 miles it follows along the strike between the Shoo Fly and Arlington formations. Southeast of Houghs Peak, however, its distribution is somewhat less regular. It breaks across the older strata; sending dikes 
into them and covering them in a broader area, which extends south of the fortieth parallel for many miles.

A second and much smaller area lies between the Peale and Robinson formations, crossing Genesee Valley a mile east of the post-office. It seems most probable that the lavas of this small area, though of Carboniferous age, are somewhat younger than those of the Taylor Rock area. The Peale formation apparently belongs between them.

It seems most probable that the masses of meta-andesite west of Taylorsville, as well as that of the mounds in Indian Valley, the point northeast of Crescent Mills, and the larger mass of Keddie Ridge and Keddie Peak, belong to the Taylor meta-augite andesite. Much of it is like the Fant meta-andesite, to be described presently.

Relations to adjacent formations and age.-In considering its occurrence emphasis was placed on the fact that it lies between the Arlington and Shoo Fly formations and would therefore appear to be of contemporaneous eruption interstratified with Carboniferous rocks. Dikes have been found running off from the main mass near Taylor Rock into the Arlington formation, but not into the overlying beds to the southwest.

\section{KETTLE META-ANDESITE.}

General description.-The principal rock included under this designation is decidedly porphyritic, with many small phenocrysts of feldspar and some of hornblende, and rarely also a few round grains of quartz. These are embedded in a reddish-brown or gray, partially crystalline groundmass, containing small grains of plagioclase and quartz. This form is most abundant on the prominent spur leading from Peters up to the Lucky S mine, also in Hornfels Point and along the east slope. of Wards Creek.

A subordinate but still abundant rock included in the Kettle metaandesite is pale greenish gray and generally nonporphyritic except in thin section under a microscope where phenocrysts of feldspar are seen altered to epidote and quartz and embedded in a fine groundmass full of feldspar microlites. This form is most abundant along Peters Creek and in the neighborhood of Kettle Rock. Both these forms are intimately associated with fragmental rocks, mainly tuffaceous, but locally passing into fine conglomerate and sandstone.

Occurrence.-The Kettle meta-andesite is clearly of volcanic origin, and its mass is made up of an extended series of lava flows and products of volcanic explosions. The whole mass has been subject to much deformation, so as to obscure the original structure, but the individual sheets of lava and tuff are locally still visible on the steep, rocky canyon slopes of Peters, Surprise, and Lights creeks.

Distribution.-A small area lies south of Genesee Valley, but the main mass extends from Hornfels Point northwest across Peters 
Creek and Lights Creek to Moonlight and Mountain Meadows, where it disappears mainly beneath the mass of Tertiary lavas which cap that portion of the range, and which have not been completely mapped in detail.

Relations to adjacent formations.-The relation of the Kettle metaandesite to the Robinson, Trail, and Foreman formations, as shown on the map (Pl. III), appears at first glance to be that of an eruptive including dislodged masses of the formations named. It must be remembered, however, that of all the included masses on Hosselkus Creek, Peters Creek, North Arm, Lights and Surprise creeks, only one, that on Peters Creek, contains fossils, and they are in all probability of Carboniferous age. It is evident, therefore, that the relation of the Kettle meta-andesite to the Carboniferous sandstone on Peters Creek is the most important.

The Robinson beds of the limited locality on Peter Creek are red and gray tuffaceous sandstones with marked pencil structure and composed, as in the typical Robinson formation, almost exclusively of particles of volcanic rocks. By the trail they dip southwest at an angle of about $54^{\circ}$, but farther north they appear vertical and so grade into the coarser tuffaceous material by which they are bounded in all directions as to indicate that the sandstone in question is a part of the fragmental material of the great mass of Kettle meta-andesite, and that the volcanic eruptions occurred about the time the Robinson formation was deposited-that is, in the late Carboniferous. It may be noted here that in the Redding region of Shasta County, where the structural relations are much simpler, there are great masses of volcanic material at about the same geologic horizon.

Tuffaceous sandstones were found at a number of localities within the Kettle meta-andesite, but microscopic sections revealed no fossils. - Some were not marked on the map, but others were, and it is possible that all may belong to the Robinson formation. This, however, does not seem probable in the areas marked as belonging to the Trail and Foreman formations, where the masses are large and the lithologic resemblance close to the nearest masses of sediments. The long, narrow belt of the Trail formation crossing: Hornfels Point is vertical and appears to be folded or faulted down into the meta-andesite. In the Surprise Creek areas the rocks are like those of Evans Peak and have a gentle dip to the southwest directly into the meta-andesite, from which it is most likely separated by a fault.

On the north side of Genesee Valley the Kettle meta-andesite is converted into hornfels along its contact with the granodiorite, showing conclusively that the meta-andesite is older than the diorite. It is important to note in this connection the occurrence in the tuffaceous Kettle meta-andesite conglomerate of pebbles of red jasper 
and of a reddish granitic rock. The latter is composed of red orthoclase and quartz with marked graphic texture and includes a few scales of mica. The jasper may come from earlier Carboniferous rocks, but the source of the other is unknown.

\section{REEVE META-ANDESITE.}

General description.-White crystals of plagioclase are plentifully scattered in a compact dark groundmasss, giving the rock a conspicuous porphyritic structure. No phenocrysts of augite are present, and the dense groundmass appears largely amorphous and is full of feldspar microlites, generally without any definite ferromagnesian silicate. In one case, however, the groundmass was found to be holocrystalline and composed of many ledge-shaped crystals of plagioclase, with grains of augite and magnetite filling the angular spaces between them as in diabase.

Though some of the material appears to be a solid lava flow, much of it is fragmental yet decidedly porhpyritic, and distinguishable from the other chiefly by the fact that it contains a variety of wellpreserved fossils and grades into the sandstone of the Robinson formation. In places the rock has been so squeezed as to develop a slaty structure, in which the phenocrysts of feldspar are drawn out long in the plane of cleavage.

Occurrence and distribution.-It occurs as a definite flow and tuff which forms a long, narrow belt running northwest from Robinson's house in Genesee Valley and bounded on both sides by fossiliferous beds of the Robinson formation. A remarkable expansion of this area occurs a mile northwest of Robinson's and is succeeded in the same direction by a narrow dikelike mass which is remarkable for its schistosity, suggesting that its narrowness is due to compression.

A second belt similar to the first borders the Robinson formation on the west, but its long, slender, dikelike south end does not. quite reach Genesee Valley. South of Genesee Valley a small area of the Reeve meta-andesite occurs east of Wards Creek.

North of Indian Valley four areas occur (Pl. II) which have not been mapped in detail. The first and principal area is a long, narrow belt extending northwest from near the Lucky S mine to Moonlight; the second is at the head of Cooks Canyon, and the other two lie on the slopes east of Mountain Meadows in line with the principal mass already noted.

Relation to adjacent formations and age.-The intimate association of the lava and tuff with the Robinson formation, into which the tuff grades, as well as the fossils contained in the tuff, fixes the age of the igneous eruption as in the late Carboniferous. The long southern extremity of the western area has the form of a dike cutting the earlier meta-augite andesite, which may belong to the same horizon as that of 
Taylor Rock, though it seems to be somewhat later in the Carboniferous. These horizons of vigorous volcanic activity in the Carboniferous correspond closely to those of the Redding region of Shasta County described in the Redding folio.

The relation of the Reeve meta-andesite to the Kettle meta-andesite is not clear, though it appears to penetrate the volcanics as a dike, indicating that the Kettle meta-andesite is the older.

JURASSIC.

\section{FANT META-ANDESITE.}

General description.-The Fant meta-augite andesite is a greenish to reddish-brown rock which is more or less porphyritic, sometimes with augite, but often with plagioclase in a groundmass made up of small crystals and grains of feldspar, augite, and magnetite, and generally with some amorphous matter. Occasionally it is conspicuously porphyritic with an abundance of greenish crystals of plagioclase in a reddish groundmass. When the phenocrysts are of augite they are inconspicuous in a greenish groundmass. The most abundant form of this meta-augite andesite is fragmental, and it is composed of material ejected by volcanic eruption, so that it is tuffaceous. It is generally fine, the fragments being under an inch in diameter and often amygdaloidal.

Occurrence and distribution.-The Fant meta-augite andesite occurs in flows, forming with its associated tuff irregular layers parallel generally to the stratification of the adjoining sedimentary rocks. The flows and tuffs being irregular, it is difficult to determine their general position, but where best exposed they dip to the southwest.

It forms a broad belt extending a little west of north from the lower slope of Grizzly Mountains across the western slope of Mount Jura to North Arm of Indian Valley. The south half of the belt is narrow, but the north half is wide and irregular.

Relation to adjacent formations and age.-Along the west slope of Mount Jura at a number of points the Fant meta-augite andesite contains included fragments of the adjacent Hardgrave sandstone, so there is no reasonable doubt that the meta-augite andesite is younger than the Hardgrave sandstone, though in the overturning of the Jurassic strata on Mount Jura the Hardgrave sandstone was placed on top of the meta-andesite.

On the other hand, this overturning of the Jurassic rocks has brought the meta-andesite on top of the Thompson limestone. At both the north and the south end of Mount Jura, as well as on its western slope directly south and southwest of the summit, the Fant meta-andesite lies between the Hardgrave sandstone and the Thompson limestone, and while it contains fragments of the former the 
contact with the latter is such as to show the deposition of the limestone on the meta-andesite. This portion of the meta-andesite is of volcanic effusion during the early Jurassic in the interval between the deposition of the Hardgrave sandstone and the Thompson limestone.

\section{HULL META-ANDESITE.}

General description.-This greenish to reddish meta-andesite is like the Fant meta-andesite just described, though the fragmental phase and the porphyritic phase rich in feldspar phenocrysts are relatively not so abundant. The prevailing type is greenish and essentially nonporphyritic, and occasionally in the Little Grizzly Creek region it is decidedly amygdaloidal.

The rock in general is only partially crystalline and is made up essentially of plagioclase and augite or their alteration products, chiefly epidote, chlorite, and some quartz. In a few cases it was found wholly crystalline, with the angular spaces between the crystals of plagioclase filled with augite and magnetite as in diabase. In a few cases also, especially in the dikes cutting the metarhyolite, it contains primary granular quartz in the groundmass as in the quartzaugite diorites.

Occurrence and distribution.-Much of it is in more or less welldefined sheets representing lava flows and tuff and is exposed in the neighborhood of Little Grizzly Creek, where the older rocks are generally covered. The mass which splits the belt of Peale beds southeast of Genesee is intruded between the strata. North of Indian Creek the mass narrows and becomes dikelike. It is decidedly slaty and near the divide cuts across the belt of Peale beds as well as the later formations to the east. More definite dikelike masses occur on the north and south slopes of Mount Jura, and it is possible that it occurs also as dikes within the area marked as Fant meta-augite andesite but was not recognized. Definite dikes occur also cutting the metarhyolite and sedimentary rocks just north of Tower Rock and elsewhere along the slopes of Grizzly Mountains.

Relation to udjacent formations and age.-The fact that it penetrates the Mormon sandstone, and especially also the Foreman beds northeast of Mount Jura, indicates that its eruption took place after the deposition of the Foreman formation and most likely near the close of the Jurassic.

\section{LATE JURASSIC OR EARLY CRETACEOUS.}

SERPENTINE.

General description.-Much of the material included under this designation is typical green serpentine which readily splits up into slickensided lenticular pieces, but it contains nodules and large masses of a prevailingly dark rock with the texture of granite but 
exceedingly tough. This rock is enveloped and permeated with serpentine and shows the rock from which the serpentine was derived by alteration. It varies greatly in composition. The most abundant form is composed almost wholly of a light-colored pyroxene with a small amount of dark-green hornblende. Occasionally the hornblende increases and plagioclase appears, so that the rock passes into phases related to gabbro or diorite, though it is for the most part a pyroxenite. Serpentine is frequently derived from peridotitethat is, a rock rich in olivine-but in the serpentines of the Taylorsville region no definite trace of olivine was found.

Distribution, relation to other rocks, and age.-The serpentine of the Taylorsville region occurs in irregular stocks like that of Grizzly Mountains and Round Valley Reservoir, but may be elongated like that of Mfontgomery Creek or run out into long, narrow dikes like those of the east slope of Grizzly Mountains. The serpentine intersects the metarhyolite of Grizzly Mountains and all the Paleozoic rocks with which it is associated in the Taylorsville region, but does not come in contact with later sediments. On the other hand, the serpentine is cut by quartz diorite and dikes of the later rhyolite, and belongs among the first eruptions of the late Jurassic or early Cretaceous.

\section{GRANODIORITE.}

General description.-The rock included under this head is a lightcolored and for the most part medium-grained rock which looks like granite. It is composed chiefly of plagioclase feldspar and quartz, with a small amount of dark-green hornblende and black mica and a trace of orthoclase, magnetite, pyroxene, and other accessory minerals. One of the best exposures of this rock is by the road near Flournoy's, at the head of Genesee Valley. At different localities the relative proportions of the minerals named above vary greatly. The rock is generally quartz diorite, but locally the orthoclase may increase and the rock passes into granodiorite. Pyroxene occasionally becomes prominent near the borders of the mass and the rock passes into quartz-pyroxene diorite, a good example of which occurs on the Cosmopolitan mine road, 2 miles west of Flournoy's. The abundance of pyroxene and the almost complete absence of quartz gives this finer grained rock a darker color than that of Flournoy's. Another variation which is peculiar in containing tourmaline occurs south of Moonlight. It is dark colored and fine grained, with considerable quartz and much hornblende, sometimes grouped so as to make the rock dark spotted. The dark-brown tourmaline is not prominent in the hand specimen but becomes so in thin section, where the crystals are seen to be grouped with radial arrangement.

Occurrence and distribution.- The.quartz diorite and granodiorite which form the bulk of the north end of the Sierra Nevada east and 
northeast of Genesee Valley are part of the great mass of the range farther south. Their apparently irregular distribution is due to the partial cover of Tertiary volcanics. Near the head of Mountain Meadows is a mass of quartz diorite, which is separated into several areas by auriferous gravel. It is rich in quartz and hornblende, and fine grained like that along the western border of the great mass about Lights Canyon. Several isolated dikelike masses occur, one along Houghs Creek southwest of Taylorsville, between the Taylorsville and Arlington formations, and another northeast of Crescent Mills, where it cuts metarhyolite. A small round mass cuts the serpentine southwest of Greenville, and a similar but smaller mass occurs near the fortieth parallel in the Kettle meta-andesite.

Relation to adjacent formations 'and age.-On the north side of - Genesee Valley the quartz diorite comes in contact with the Swearinger slate, the Trail formation, and the Kettle meta-andesite. Along the contact the quartz diorite has locally converted adjacent portions of all these formations into dark flinty hornfels, which is abundant in places along the crest of Hornfels Point. While it is certain that the irruption of the quartz diorite took place after the deposition of the Trail formation, its relation to the other Jurassic formations in the Taylorsville region could not be determined. In the Downieville region, however, Turner has shown that the irruption occurred after the deposition of the Milton formation, which is equivalent to at least part of the Taylorsville Jurassic.

As to its neighboring igneous rock, the quartz diorite is clearly younger than the Kettle meta-andesite and the metarhyolite which it intersects, but in the canyon north of Round Valley Reservoir it is cut by dioritic dikes, which must be considered the younger.

\section{VARIOUS DIKE ROCKS.}

General description.-The most common dike rock varies in color from light gray to pale green and reddish brown. Small phenocrysts of quartz are always present, but it is rarely porphyritic; except in the reddish-brown form; which is full of phenocrysts of feldspar. It is rhyolite, but lacks entirely the brecciated feature which is so generally prominent in the metarhyolite, and in but few localities does it show fluidal structure.

Another form, which has no quartz phenocrysts and looks much less siliceous, is made up almost wholly of plagioclase and green hornblende. It is a fine-grained greenish diorite. The occurrence and distribution of the rhyolite will be considered first and then that of the diorite.

Occurrence and distribution.-The forms are distinct dikes and small circular or angular patches. One and a half miles west of Greenville there are a number of dikes running a little west of north 
through a small area of banded slates belonging to the Taylorsville formation. The largest of the dikes is about 75 feet in width, but could not be traced more than a mile along the strike.

From Round Valley Reservoir, about one-third of the way down North Canyon to Greenville, the granitic rock is intersected by a dikelike mass of rhyolite nearly 100 feet in width. It forms prominent cliffs and falls along the stream. Just below the Phœnix Mill the dike strikes nearly east and west. Locally the rock looks like a microgranite; and under the microscope shows remarkable graphic intergrowths of quartz and feldspar.

A mile and a half west of Taylorsville there are four dikes and irregular patches of rhyolite apparently cutting the meta-augite andesite and Taylorsville formation, while 2 miles south of Taylorsville distinct dikes of rhyolite occur in serpentine.

On the west slope of Mount Jura there are a number of small masses of rhyolite. Those associated with small areas of Hardgrave sandstone have been derived by faulting from the large mass to the west, but some of the others appear to be intrusive in the meta-andesite. The most distinctive mass, nearly circular in outline, occurs about a mile southwest of the summit of Mount Jura. The rock is reddish brown in color and decidedly porphyritic, with many small crystals of feldspar and quartz. The quartz is rounded and embayed, and the feldspar is at least in part plagioclase and generally much altered. Microscopic traces of altered hornblende are scattered through the groundmass. The relations of this mass to the adjacent metaandesite were not clearly made out, but it is believed that the rhyolite penetrates the meta-andesite.

A short distance farther south is a dikelike mass of rhyolite nearly a mile. in length. The rock is greenish and nonporphyritic, like the dikes in the serpentine, and appears to hold the same relation to the meta-andesite as the porphyritic type just noted.

Half a mile northwest of the summit of Mount Jura is a mass of rhyolite cutting across a belt of meta-andesite that intersects the Mormon sandstone, and near the center of section 24, $2 \frac{1}{2}$ miles northeast of Taylorsville, is a small mass lying between the Mormon sandstone and meta-andesite. A third mass, about a mile north $10^{\circ}$ east from the summit of Mount Jura, penetrates the Foreman beds. All three masses are long and narrow and appear to be dikes, but on the divide east of Mount Jura, at the head of Hinchman Ravine, is another circular mass similar to that on the west slope of Mount Jura. It penetrates the Peale formation of Carboniferous age as well as the associated meta-andesite, and is remarkable locally on account of its distinct fluidal structure. A similar mass, holding essentially the same relations to adjacent rocks, occurs on Little Grizzly Creek near the fortieth parallel. 
The dikes of diorite were noted in the canyon north of Round Valley Reservoir. They are vertical, range from 5 to 10 feet in width, strike nearly north and south, and cut directly through the lighter-colored, coarser-grained granitic rock. Their relation to the dike of rhyolite in that vicinity was not satisfactorily determined.

Relation to adjacent formations.-In considering their occurrence and distribution the relations of the rhyolite and diorite dikes to adjoining rocks in each locality were brought out, and they appear to intersect sediments belonging to Silurian, Devonian, Carboniferous, and Jurassic formations, as well as meta-andesite, serpentine, and granodiorite among igneous rocks. They are evidently of late Jurassic or early Cretaceous intrusion. This relation to sedimentary and igneous rocks distinguishes the rhyolite dikes from the metarhyolite, which is of early Paleozoic volcanic effusion.

\section{MIOCENE.}

\section{- RHYOLITE.}

General description.-Rhyolite is a siliceous lava, generally light colored or brownish and more or less porphyritic, with grains of quartz and sometimes with scattered crystals of feldspar or biotite. All of these forms occur in the Taylorsville region in the small areas on the ridge west of Shoo Fly and half a mile south of Greenville. Perhaps the most definite rhyolite masses of the Taylorsville region are tuffs which occur in the auriferous gravels near the head of Willards Creek, 10 miles southwest of Susanville. They are grayish white and composed almost wholly of splinters and pumiceous fragments of volcanic glass. The following chemical analysis of it was made years ago by George Steiger and published in United States Geological Survey Bulletin No. 228, page 211:

Analysis of rhyolitic tuff from Willards Creek, near Susanville, Cal. •

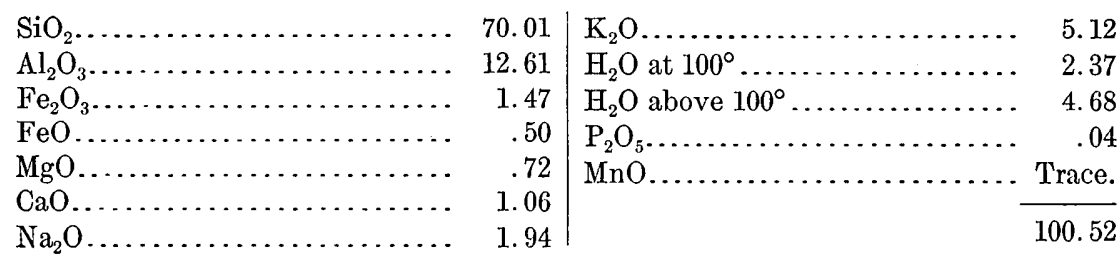

Distribution and relations. - On the ridge west of Shoo Fly are two small areas of rhyolite. They differ somewhat in color, yet possibly belong to the same flow. At the southern locality the rhyolite apparently overlies gravel and is itself overlain by a flow of basalt.

South of Greenville is a small mass elongated nearly north and south and not far from the course of the line which connects the other two detached masses. It is possible, but not probable, that all these small masses are remnants of the same flow. 
Some rocks which may be rhyolitic were noted during a reconnaissance along the road in Last Chance Valley and on the eastern crest between the road and McKesick Peak. The rock is generally tuffaceous, coarser than that already noted, and not clearly rhyolitic. It lies directly on the granodiorite and is overlain by basaltic flows.

South of the fortieth parallel, in the region mapped by Lindgren and Turner, rhyolite and rhyolitic tuff are more abundant, and they directly overlie the earlier auriferous gravel. The same horizon is probably represented by the rhyolitic tuff on Willards Creek, which, on account of the smallness of the area, is included on the map . (Pl. II) in the auriferous gravels.

PLIOCENE.

\section{ANDESITE.}

General description.-Andesite is a lava, usually light gray, which, though not generally porphyritic in the hand specimen, becomes more or less clearly so in thin section. Crystals of plagioclase are numerous; those of hornblende, biotite, and pyroxene are somewhat less abundant but in various proportions. The felty dark gray groundmass inclosing the phenocrysts contains many minute microlites of feldspar and black grains of magnetite in a light-brown glassy base.

In some cases the hornblende phenocrysts are abundant, surrounded by dark borders, and the rock is a typical hornblende andesite. In other cases hornblende is practically absent and pyroxene is the characterizing mineral. All these forms are generally accompanied by a great deal of andesitic breccia and tuff from explosive volcanic action.

Occurrence and distribution.-It occurs in sheets, forming a blanket covering the older rocks around the volcanic vent from which the flows and ejected material issued. "There were many vents, and the cover was continuous over a large part of the region. Erosion has removed the cover in places and left isolated patches, sometimes revealing the volcanic necks through which the material reached the surface. This is especially the case in Lone Rock, which is a conspicuous peak surrounded by cliffs. A less conspicuous example occurs in Indian Creek, between Lone Rock and Thompson Peak. Both of these masses are of hornblende andesite, closely related to that north of Kettle Rock, as well as the isolated patches near Hosselkus Valley, on Hornfels Point, and on the divide at the head of Foremans Ravine.

The andesite by the chalybeate soda spring near Arlington Bridge is black and breaks with very irregular fracture. It is slightly porphyritic with crystals of plagioclase embedded in a groundmass full of small lath-shaped feldspars with grains of augite embedded in a dark globulitic base. The lava came down from the slope a short 
distance south. The andesite overlying the gravel a mile northeast of Greenville is much richer in augite and poorer in amorphous matter than that of the Arlington spring. Its source is not definitely known, but it probably issued from a vent at the southeast end of the exposure.

The large continuous sheet of volcanic rocks along the fortieth parallel, about the heads of Squaw and Last Chance creeks, is in part hornblende andesite, with some pyroxene andesite and a smaller proportion of basalt and rhyolite which has not been mapped separately.

The andesitic tuff and breccia which form Diamond Mountain are full of black-bordered hornblende, but in Red Mountain the hornblende has largely disappeared and the prevailing ferromagnesian silicate is pyroxene.

The area between Moonlight and Mountain meadows is mainly hornblende andesite on the eastern side and pyroxene andesite on the western slope, though the two are intermingled. The same is true of the Cheney Creek area and the small area north of Nanney, but the larger mass which forms the end of this part of the Sierra Nevada is almost wholly pyroxene andesite.

North and east of Susan Creek much of the country has not been seen. A general reconnaissance was made by J. Stanley-Brown in 1890. Hot Springs Peak, an old volcano, was visited and is known to be andesite, though the rocks about its north base are basalt. Shaffer Peak is supposed to be of the same character.

Relation to adjacent formations and age.-North of Kettle Rock, about the head of one of the tributaries to Lights Creek, the andesitic breccia overlies auriferous gravel, and the same is true north of Moonlight, where the auriferous gravel, firmly cemented, dips westerly beneath the andesites which form the crest. The andesites and andesitic breccias in the Taylorsville region, like those of other portions of the Sierra Nevada, overlie the earlier auriferous gravels.

The earlier auriferous gravels contain many pebbles of igneous rocks derived in large measure from the Paleozoic and Mesozoic lavas already described, which are so widely distributed about the north end of the Sierra Nevada. The early gravels contain also some fragments of lava which appear less altered than those just referred to, but exposures of such lavas were not definitely recognized and distinguished from the Tertiary lavas which overlie the older gravels.

On the other hand, as explained under "Auriferous gravels," the later gravels overlie andesitic flows and are composed in some cases almost wholly of andesitic pebbles. It seems evident, therefore, that the eruptions of andesite occurred within the gravel period, overflowing the earlier gravels and furnishing the material for the later gravels. 


\section{QUATERNARY.}

BASALT.

General description.-Basalt is lava which is generally darker colored, more compact, and heavier than andesite, and, though not plainly porphyritic, yet, unlike the andesite, it frequently contains visible grains of yellowish-green olivine. In thin section it is seen to be composed chiefly of plagioclase and augite and a smaller proportion of olivine and magnetite. The dark-gray forms are holocrystalline, but the darker, compact ones have, besides the more or less abundant crystals of plagioclase, much black amorphous matter instead of augite.

Occurrence and distribution.-Basalt is somewhat less abundant than andesite in the Taylorsville region. Like andesite, it occurs generally in flows about a volcanic vent. Mount Ingalls, just south of the fortieth parallel, is a large volcano built up almost wholly of basalt. Turner has shown in the Downieville folio that Mount Ingalls is made up of earlier and later basalts, separated at least in part by a mass of andesitic tuff. The later basalt forms the bulk of the mountain and extends north over the quartz diorite to near Genesee Valley. It is dark gray, holocrystalline, and rich in augite. The earlier basalt appears along the road south of Flournoy's. It is black and compact and contains much amorphous matter. At this point the two basalts are not separated by andesite, and they are not distinguished on the map of the Taylorsville region for the reason that the subdivision of earlier and later can not be applied throughout the region. For example, the youngest basalt of the region is a flow which followed Susan Creek for miles. It is later even than the later basalt of Mount Ingalls and yet most like the older basalt.

One of the finest exposures of basalt in the region occurs at Thompson Peak, opposite Janesville. The eastern slope of Thompson Peak is a steep bluff exposing a succession of basalts and tuffs in layers from 5 to 30 feet thick dipping gently to the southwest. The exposed thickness is apparently about 1,200 feet, and the lower flow in contact with the quartz diorite is very dark and compact, like the earlier basalt of Mount Ingalls. Some of the succeeding layers are vesicular, rich in olivine, and much black globulitic base instead of augite. The summit of Thompson Peak is of holocrystalline basalt, with considerable olivine, but rich in augite occupying the angular spaces between the lath-shaped crystals of plagioclase.

Beneath Thompson Peak, on the slope toward Janesville, there are numerous dikes of basalt cutting the diorite. Some run nearly parallel with the crest of the range, and others in various directions, as if Thompson Peak were a volcanic center from which they radiated. 


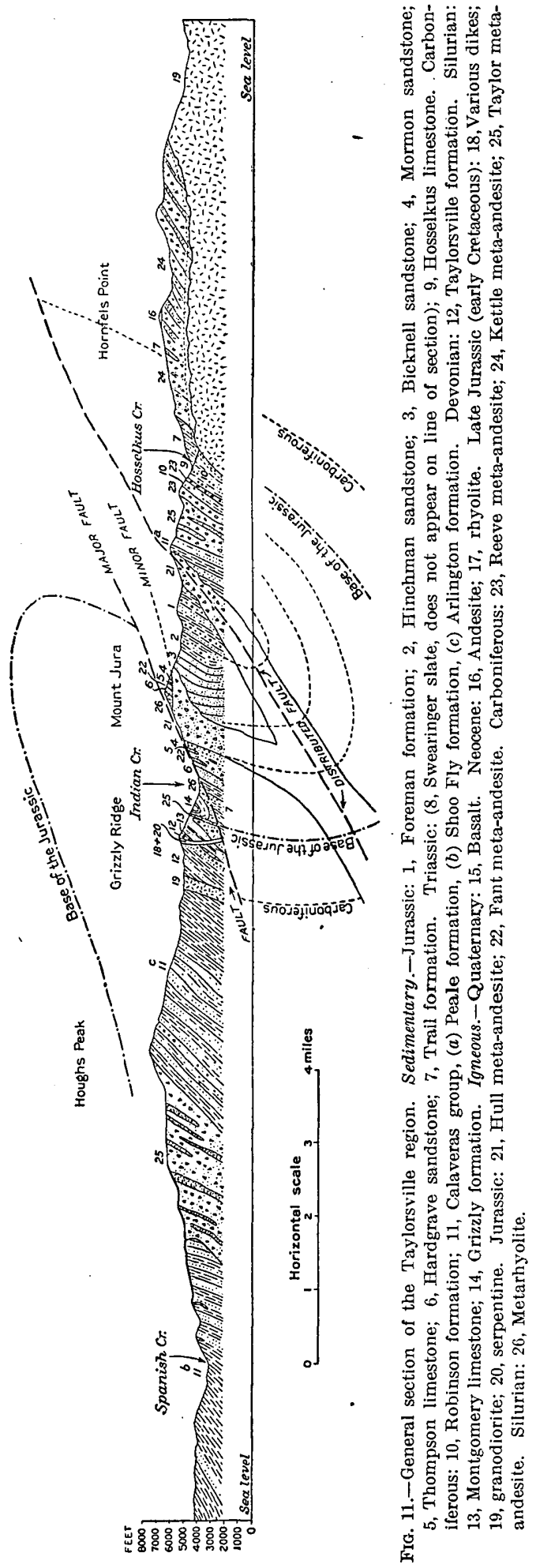

A number of small areas of basalt occur on the steep slope of the Sierra Nevada north of Thompson Peak, but the most interesting area is a small one on the very crest, a short distance south of Diamond Mountain. This little mass, not a hundred yards long east and west, lies nearly flat across the crest and ends in a bluff on the east. It is somewhat amygdaloidal, with definite flow structure from the east, and in this respect agrees with the flow structure seen in some of the flows exposed on the northeast slope of Thompson Peak.

The largest area of basalt is that which surrounds and covers the end of the range north of Mountain Meadows and in succeeding flows descends the valley of Susan Creek. It is part of the great flow which comes from the region of Lassen Peak. There may be other large areas of basalt east and southeast of Susanville, but the hasty reconnaissance of that region by J. StanleyBrown did not permit their detailed separation from the andesites.

As already stated, the latest basalt flow of the Taylorsville region is that which follows the course of Susan Creek. Others 
have followed watercourses, but their preservation is far less complete. Remnants of successive flows widely separated in time occur in the Shoo Fly region. On the crest of the spur west of Shoo Fly are two remnants of an old basalt flow in part covering rhyolite. At several lower levels are lava-capped benches which are remnants of successive flows that have occupied the bed of Indian Creek and been almost wholly removed by erosion.

\section{STRUCTURE.}

\section{GENERAL STATEMENT.}

The general structure of the Taylorsville region, as far as its sedimentary rocks are concerned, is shown in the accompanying (measured) section (fig. 11), which represents a tract 17 miles in length. Beginning on the southwest, at an elevation of 3,100 feet on Spanish Creek, it crosses Houghs Peak at 7,254 feet, and reaches Indian Creek, $1 \frac{1}{2}$ miles above Taylorsville, at an altitude of 3,500 feet. Continuing in the same course, it crosses Mount Jura at 6,000 feet about one-third of a mile south of the summit. The upper portion of Hinchman Ravine and other small ravines are crossed to reach Hos-

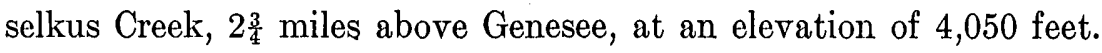
Thence the section passes over the northern portion of Hornfels Point at an elevation of 6,500 feet and skirts along the top of the southern slope of the mountain, whose summit is 3 miles directly north of Flournoy's.

The strike of the rocks throughout the region is $\mathrm{N} .5^{\circ}$ to $65^{\circ} \mathrm{W}$., and the dip, with rare exceptions in the Shoo Fly and Foreman formations, is toward the southwest at angles varying from $39^{\circ}$ to $75^{\circ}$.

The region traversed by the section may be divided into three belts: (1) 'The Mount Jura or middle belt, characterized by overturned strata; (2) the Grizzly Mountains or west belt, in which the strata are not overturned; and (3) the east belt, of diorite, which forms the eastern part of the range.

MOUNT JURA BELT.

The Jurassic strata of Mount Jura have been completely overturned. Their general dip is to the southwest. The Hardgrave sandstone lies on top, with the Thompson limestone, Mormon sandstone, Bicknell sandstone, Hinchman tuff, and Foreman beds in a descending but successively younger series dipping beneath the Hardgrave sandstone. This order of superposition is well exposed on the west slope of Mount Jura, and also on the slope toward Hinchman Ravine. The formations are all well characterized by fossils. As there can be no question concerning their relative age determined by Professor Hyatt, it is evident that they have been overturned. 
The overturning involves also the Triassic and Carboniferous strata east of Mount Jura on Hosselkus Creek, where the Trail beds of the Jurassic dip beneath the Swearinger slate and Hosselkus limestone of Triassic age, and these in turn dip beneath the Robinson formation of Carboniferous age.

The belt of overturned strata, embracing those of Mount Jura, after which the belt is named, and the country to the east as far as Hornfels Point, is 6 miles in width. The strata involved have a thickness of about 9,000 feet. All of the strata in this belt are overturned toward the northeast, and this is evidently the result of a great thrust from the southwest.

\section{GRIZZLY MOUNTAINS BELT.}

The Grizzly Mountains belt of strata, lying southwest of Indian Creek, is over 12 miles in width in the Taylorsville region and extends beyond its limits. The oldest strata, those of the Grizzly formation, are Silurian, and they dip to the southwest. They are overlain in regular succession by the Montgomery limestone, Taylorsville formation, and Arlington beds, all Paleozoic, and also by a great mass of interbedded volcanics, succeeded by the Shoo Fly formation of Carboniferous age. The whole mass has a thickness of over 14,000 feet. The dip between Indian Creek and Houghs Peak is not over $45^{\circ}$, but west of the volcanics, in the Shoo Fly formation, the dip is increased and may be reversed to a limited extent by local causes. On the whole, this belt is strongly contrasted with that of Mount Jura in that the sedimentary rocks of the Grizzly Mountains belt are older than the middle Carboniferous, are only moderately disturbed, and occur in regular succession, while those of the Mount Jura belt are all younger and much disturbed with interrupted succession.

\section{- GRIZZLY MOUNTAINS ANTICLINE.}

The Grizzly Mountains belt of strata dipping to the southwest appears to be one arm of an anticline of which the other arm has disappeared. The anticline was overturned toward the northeast by thrust from the southwest. Continued thrusts broke the arch and gave rise to an overthrust fault on which the southwest arm of the anticline appears to have been shoved up over the northeast arm, as shown in the section in fig. 11. This movement and consequent. erosion brought to the surface the metarhyolite upon which the Hardgrave sandstone was deposited in the early Jurassic.

MOUNT JURA SYNCLINE.

Adjoining the Grizzly anticline upon the northeast is the Mount Jura syncline, a region of subsidence which may have continued an area of deposition long after deposition ceased over the crest of the 
Grizzly arch, and thus became filled with strata which have no equivalents in the Grizzly arch or on the southwest slope of the Sierra Nevada.

The earliest evidence of this sort concerning the Mount Jura syncline is the presence of the Robinson formation, which is the latest Carboniferous known in the Sierra Nevada, and which lies northeast of the main crest of the Sierra Nevada chiefly in the Mount Jura syncline, and indicates that the Mount Jura syncline may have begun as early as the Carboniferous. Later the same region of depression received an extensive series of Triassic and Jurassic deposits not found west of the main crest at the north end of the range.

The thrust from the southwest which overturned and faulted the Grizzly arch overturned the adjoining arm of the Mount Jura syncline. In Mount Jura and the country to the east, including Hornfels Point, there is no repetition of strata, a feature which indicates that all belong to the southwest arm of the syncline, for all are included in the overturning. The relation of the adjoining portions of the Grizzly anticline and the Mount Jura syncline, though well exposed in the line of the general section (fig. 11), may be seen to advantage 2 miles farther southeast, where several patches of Hardgrave sandstone occur on the lower slope of Grizzly Mountains.

The structure of the syncline is not as simple as it was formerly supposed. The irregularity in the distribution of the Carboniferous, Triassic, and Jurassic within the syncline may be attributed to the folding of the Carboniferous, and later of the Triassic, before the Jurassic strata were deposited.

The entire disappearance of the Jurassic portion of the eastern arm of the syncline is most probably due, as shown in the section, to a large amount of distributed thrust faulting - the Hull fault, that gave rise to the prominent slaty structure in the mass of Hull meta-andesite which separates the youngest Jurassic (1) from the Carboniferous $(11, a)$. This igneous rock appears to have been intruded diagonally into the syncline and afforded a plane of easy displacement to relieve the strain in that greatly compressed mass.

\section{TAYLORSVILLE FAULT.}

The fault developed between the Grizzly Mountains arch and the Mount Jura syncline lies near Taylorsville and follows approximately the eastern border of the metarhyolite from the lower slope of Grizzly Mountains through the canyon of Indian Creek above Taylorsville and along the eastern slope of Keddie "Ridge, as indicated on PI. III. The metarhyolite a mile northeast of Taylorsville is greatly crushed and evidently marks the course of the fault. 
This fault appears to have been a line of displacement during the latter portion of the Carboniferous and to have aided in large measure in bringing the metarhyolite to the surface, so that in the Jurassic the Hardgrave sandstone was deposited on the same rock which received the Grizzily quartzite in the Silurian.

It was motion along essentially the same narrow zone that folded and overturned the strata in the Mount Jura syncline. Of this there is proof in the southern slope of Mount Jura, where the Hardgrave sandstone, Thompson limestone, and Mormon sandstone, with the associated metarhyolite and Fant meta-augite andesite, are repeated by a fault in the same order and position. This displacement followed the overturning, for the fault enters the overturned beds and shoves them along farther in the same direction.

The hade of the Taylorsville fault appears to be about the same as the west slope of Mount Jura, where some faulted masses cling to the slope dipping southwest into the base of Grizzly Mountains, but toward the summit of Mount Jura the fault plane enters the mountain and passes through to the other side, emerging at the base of the Mormon sandstone. The faulted mass is over 2 miles in length and half a mile in width, and much lower at the southern than at the northern end.

The amount of displacement on the Taylorsville fault near the close of the Paleozoic may have been great, but no data are available for its estimation. As to the post-Jurassic faulting along this line, the amount can be measured in miles, for a large part of the movement was involved in the overturning, and after the overturning was complete the movement on the fault was about a mile.

The Taylorsville fault does not extend far southward. No movement in its line was detected by Turner south of the fortieth parallel, and it is of importance to note that in the Downieville quadrangle all the Jurassic strata lie east of the axial line of the Grizzly anticlinal, and what is of greater significance is that they all dip to the east; that is, they have not been overturned like those of the Taylorsville region.

Near the fortieth parallel an ancient stream bed of auriferous gravel crossed the line of the fault, but has suffered little if any dislocation at that point, though elsewhere in the same region there has been extensive faulting since the gravel period.

\section{HULL FAULT.}

The Hull fault is a branch of the Taylorsville fault and circumscribes the mass of Mount Jura on the east. It follows the Hull meta-andesite throughout the greater part of its course from the fortieth parallel northwest to North Arm. The fault adjusts the overturned Jurassic strata on the west to the Carboniferous on the east and is expressed in the decided slaty structure of the Hull meta-andesite. 
In the neighborhood of Honey Lake the Sierra Nevada is bounded on the northeast by a prominent escarpment due to faulting. 'The escarpment, about 2,000 feet in height, is composed of quartz diorite, which is overlain on the crest by auriferous gravel with a local capping of andesitic breccia in Diamond Mountain, as illustrated in fig. 10. Lava and gravel similar to those of the summit are found locally along the foot of the escarpment, but in most places they are covered by later deposits. Following the escarpment northwest to Gold Run, where the wagon road crosses the range, the gravel is found to be firmly cemented and bent down over the eastern slope of the range so as to connect that of the mountain crest and foot. The escarpment ends at this point and the fault by which it was produced passes into a monoclinal fold. The fold continues to the northwest in the old lavas of the region for about 12 miles and then disappears beneath the newer lavas from the vicinity of Lassen Peak.

From the fact that the Honey Lake fault passes into a monoclinal fold, it is evidently a normal fault and strikingly unlike the Taylorsville fault. The total displacement of the Honey Lake fault is at least 2,000 feet and may be somewhat greater, and it is clearly later than the auriferous gravels and andesitic flows of the Diamond Mountain region.

To the southeast, as shown in Pl. I, the Honey Lake fault extends through a portion of Long Valley into Nevada, where it apparently turns more to the south and possibly connects more or less directly with the main fault along the east front of the Sierra Nevada, which Lindgren has traced as far north as Reno.

In the Truckee region Lindgren has recognized three faults, approximately parallel. The main fault, the one just referred to, lies close along the eastern front of the range from Markleeville to Reno. The other two (see Pl. I) are farther west, one on either side of Lake Tahoe, and bound the sunken area or moat, as Lindgren ${ }^{a}$ appropriately designates it, which extends as far northwest as Sierra Valley. East of Lake Tahoe is a prominent ridge or "buttress" which extends up between the Tahoe moat and the sunken region of the Great Basin.

According to Lindgren, these faults were formed during the early Cretaceous. On the eastern fault there was a displacement of 3,000 feet in the early Cretaceous, followed at the close of the Miocene by a displacement of 2,000 feet. This final movement in all probability was contemporaneous with the faulting along Honey Lake.

It is probable that movements along that fault have taken place in recent times, if earthquakes may be accepted as evidence in that direction. A few years before 1885 there were a number of small 
earthquakes whose region of greatest intensity lay along the foot of the Honey Lake escarpment, particularly at Janesville, where objects were thrown from the walls and mantles in dwellings and chimney tops were overthrown. Although the earthquakes were probably due to slight movement along the old fault plane, yet no fissures were visible on the surface, as was the case along Inyo Valley after the great earthquake of 1872 .

\section{MOHAWK VALLEY FAULT.}

The fault along the west side of Lake Tahoe (Pl. I) Lindgren has traced northwest from Mount Tallac by way of Donner Lake, Lake Independence, and Webber Lake up toward the southwest corner of Sierra Valley and Mohawk Valley, where it has been studied in detail by Turner, who remarks in the Downieville folio that-

$\approx$ The best evidence that a great displacement has occurred here in Tertiary time consists of the presence of river gravels on the high plateau to the west. At one point about $2 \frac{1}{2}$ miles northwest of Haskell Peak there is a heavy mass of well-rounded gravel at the very edge of the escarpment, and a considerable portion of this mass has by gravity traveled down the slope, so that the apparent thickness of the deposit is about 500 feet. To the northeast and west of Haskell Peak, and also close to the edge of the escarpment, are smaller masses of similar gravel, all of them capped with rhyolite and all at an elevation of about 7,000 feet. It is evident that we have here remnants of an old river deposit formed by a stream flowing at a moderate grade. It is not likely that such a stream could have existed along the edge of a plateau having a steep escarpment. There can be no reasonable doubt that since these gravels were deposited a profound displacement has occurred, in virtue of which that portion of the former plateau lying to the east of the present escarpment has dropped down 2,000 or more feet and now lies buried beneath the sediment of the former Mohawk Lake and beneath the Tertiary lavas.

An earthquake occurred in this valley in 1876, which resulted in forming a fissure 2 feet wide and invigorating a number of hot springs along the line of the former fault.

Northwest of Mohawk Valley Turner has found fault scarps at a number of points, but especially along Spring Garden Creek and farther west along the base of Spanish Peak in Meadow Valley, where there appears to have been a displacement of 3,000 feet since the deposition of the auriferous gravels. This fault has been referred ${ }^{a}$ to as the American Valley fault. Continuing northwest in the line of the faulting across North Fork of Feather River, about the head of Chip Creek, several faults occur in the lavas of the Lassen Peak region. Forty miles farther northwest, in the same line which passes to the west of Lassen Peak, a low arch in the older rocks comes out from under the lavas and crosses Pit River into the Klamath Mountains about 20, miles northeast of Redding. This line of displacement appears to be the one connected with the main crest of the Sierra Nevada, and its influence was felt in the Klamath Mountains.

$a$ Bull. U. S. Geol. Survey No. 33, 1886, p. 13; Eighth Ann. Rept. U. S. Geol. Survey, pt. 1, 18s9, p. 426. 
The length of this faulted belt (shown in Pl. I) from Lake Tahoe to beyond Spanish Peak is over 50 miles, and to Pit River nearly as far again. Though a definite fault line can not be traced all the way, there are places where it is evident. In the Lake Tahoe region, as shown by Lindgren, the faulting on this line occurred chiefly, if not wholly, in the early Cretaceous, but in Mohawk Valley and farther northward the faulting appears to have been chiefly, if not wholly, later than the gravels. The arch, which in the Redding folio is called the Copper City arch, is bordered by fossiliferous rocks which show it to have been formed after the Chico and before the Ione. It is likely, therefore, that the early Cretaceous movement which Lindgren recognized about Lake Tahoe reached the Klamath Mountains about the close of the Cretaceous, but that the greatest amount of displacement along that line in the north end of the Sierras took place after the earlier gravel period.

\section{INDIAN VALLEY FAULT.}

Having traced the Honey Lake fault from its north end, where it passes into a monoclinal fold, southeast to the neighborhood of Reno, and the Mohawk Valley fault from Lake Tahoe to the lavas of Lassen Peak and beyond to the Klamath Mountains, let us turn our attention to the line of faulting that lies between the two already noted.

Lindgren has traced a fault from the eastern side of Lake Tahoe northwest across the Truckee into the divide which bounds Sierra Valley on the south. The divide is of volcanic rocks, which Lindgren regards as younger than the fault and which obscure its topographic features. No definite trace of the fault was seen about Sierra Valley, though it may cross in the vicinity of Loyalton and Beckwith, for continuing northwest beyond Sierra Valley we come to Grizzly Valley, which is in line with Indian Valley, where we find in the strong contrast of the two sides of the valley decided evidence of faulting. On the south side are the bold bluffs of Arlington Heights and Houghs Peak, which expose the ends of a thick series of sediments dipping to the southwest, while on the opposite side-beyond the valley is a gentle slope, whose topographic features run beneath the north edge of the valley. The Mounds of Indian Valley are knolls which occur on a spur that runs out under the valley. The knolls are sufficiently prominent to rise above the floor of the valley. They are completely surrounded by alluvium, but clearly belong to the spur on the adjacent side of the valley and show that the deep side of the valley is on the south, under the prominent bluffs. The fault is a short one between Taylorsville and Crescent Mills and possibly around to Greenville. The amount of displacement is small. No definite trace of this fault has been found in the canyon of Indian Creek above Taylorsville, where the effects of the Taylorsville reverse fault are in evi- 
dence. The absence of the Arlington beds on the metarhyolite north of the valley, as explained on page 100 , is in large measure due to preJurassic erosion. The Indian Valley fault is normal, like that of Honey Lake and Mohawk Valley, and is not to be confused with the Taylorsville reverse fault of the same region.

Northwest of Indian Valley, at the lower end of Big Meadows and Mountain Meadows, the rocks of the Taylorsville region pass beneath the cover of Miocene lavas from the volcanic center about Lassen Peak. North of Prattville, along the northeast edge of Big Meadows, there is a prominent lava bluff due to faulting. Along Rock Creek and also along Warner Creek of the same region, as shovil in Pl. I, similar bluffs occur, all approximately parallel and facing the southwest. They are due to faults and have been traced about a dozen miles running nearly N. $30^{\circ} \mathrm{W}$. in line with the faulted belt we have traced from Lake Tahoe by way of Grizzly and Indian valleys. Continuing to the northwest, the same line passes east of Lassen Peak in the vicinity of the Snag Lake cinder cone to the prominent fault scarp known as Hat Creek Hill. It faces the southwest. The throw at the south end is over 600 feet, but it decreases to the northwest, and the fault continues for over 20 miles to near Pit River.

The faults of the Indian Valley belt in the Lassen Peak region are remarkable not only for their extent, but also from the fact that they have the downthrow on the southwest side and are of post-Miocene age.

Along Indian Valley the fault may be of about the same age, but the throw is in the opposite direction. In the vicinity of Lake Tahoe, as Lindgren has shown, there was little or no movement at the close of the Miocene. The faulting in that region occurred in the early Cretaceous, with the downthrow on the southwest, similar. to that in the Lassen Peak region and the reverse of that in Indian Valley.

\section{GEOLOGIC HISTORY OF TAYLORSVILLE REGION.}

\section{PRE-SILURIAN.}

What was happening in the Sierra Nevada region during the long eons of the early geologic time is not yet fully made out. The record is fragmentary and complex. During Cambrian time it appears ${ }^{a}$ that a mountain range may have occupied approximately the position of the Sierras and limited on the west the thick deposits of Cambrian strata laid down in the Great Basin region. Though it is known ${ }^{b}$ that Cambrian strata extend into the Sierra Nevada west of Mono Lake; they do not outcrop in the Taylorsville region, where all the rocks are of later age. 
The earliest scene drawn directly from the records of the Taylorsville region is one of decided volcanic activity, during which the metarhyolite found its way to the surface, but the extent of the volcanic eruptions, whether on land or on sea, and their exact geologic date are matters of conjecture, except that they are older than the adjacent Silurian strata.

\section{SILURIAN.}

The Silurian record began over the northern end of the Sierra on the sea floor with the deposition of fine sand and occasional pebbles of the underlying metarhyolite. Layers of dark mud were formed in places containing numerous sponge spicules, such as are found in the Grizzly quartzite, to register the life of the time. Conditions changed somewhat, and corals became abundant with other forms of organisms having calcareous shells. By their accumulation local lenses of limestone were formed, whose fossils indicate the horizon of the Niagara. The occurrence of similar fossils near Eureka, Nev., suggests direct water connection with the great water body which in Silurian time occupied the central part of the United States. The general absence of this limestone on the Pacific coast except in the Taylorsville region may indicate dry land in that region during the Silurian.

\section{DEVONIAN.}

Judging from the small size of the limestone lentils, the epoch of their development was brief. Then came changes which involved elevation, exposing parts of the Grizzly quartzite to erosion, but the Taylorsville region appears to have remained much of the time beneath the sea and to have received the conglomerates, sandstones, shales, and cherts of the Taylorsville formation. The pebbles of lava contained in the fine conglomerate at the base of the formation testify to pre-Devonian volcanic activity, including such forms as the metarhyolite, a type which occurs near the same horizon in the Redding region also. The records of Devonian life are obscure or absent in the Taylorsville region, but to the northwest in the Redding region they are abundant. The sea teemed with corals, and the middle Devonian limestone of the Klamath Mountain region is locally full of them. But the record of the Devonian period in the Sierra Nevada, though much fuller than that of the Silurian, is far from complete. The Devonian period was brought to a close by an uplift which exposed the Devonian sediments locally to erosion.

\section{CARBONIFEROUS.}

The Carboniferous opened with the northern part of California beneath the sea, receiving deposits derived largely from the erosion of Devonian strata, upon which the Carboniferous strata were laid down unconformably. The shore was not far off, for many fossil- 
iferous limestone pebbles, such as are easily destroyed, were preserved in the conglomerates of the lower Carboniferous of the Klamath Mountains. On the northern end of the Sierra the deposits were finer, composed chiefly of fine shale and sandstones, making up the Arlington formation, succeeded by the siliceous beds of Houghs Peak, with an occasional conglomerate. Then came an epoch of vigorous volcanic activity whose products are widespread. At this time the volcanic tuffs and flows of the Taylor meta-andesite 'were erupted, and volcanoes were active in the Sierra south of the fortieth parallel ${ }^{a}$ as well as in the Redding region ${ }^{b}$ of the Klamath Mountains. With the decadence of volcanic activity conditions favorable to the formation of limestone came in and heavy bodies of limestone locally full of fossils were formed throughout the Sierra and the Klamath Mountains. Toward the end of the Carboniferous volcanic action again became vigorous, resulting in the eruption of the Reeve and Kettle meta-andesites, but small lenses of limestone continued to be formed in places to the end of the period, which was brought to a close by an uplift in the Taylorsville region. This uplift in the Sierra Nevada region corresponds approximately to that of the Mississippi Valley and the eastern portion of the United States, where the Appalachian Mountains were formed and the ocean in large measure finally excluded from the Mississippi Valley. In the Sierra it appears to have been accompanied by considerable deformation and metamorphism and possibly erosion before the deposition of Triassic began, for the Paleozoic strata are decidedly more compressed and altered than those of Mesozoic age in the same region, ${ }^{c}$ and the two are unconformable. As one of the results consequent upon the deformation of the Taylorsville region, the Taylorsville fault was formed and rhyolite was brought to the surface to receive the Triassic and Jurassic deposits laid down upon it.

\section{TRIASSIC.}

During the early Triassic the Taylorsville region appears to have been dry land, but to the northwest in the Redding region the sea prevailed, receiving upon its floor a thick deposit of lavas and tuffs interstratified with and succeeded by shales and thin sandstones of the Pit formation, which does not occur in the Taylorsville region. The northern end of the Sierra subsided, but without great deformation, at the close of Pit time, and the sea again covered a large part if not the whole of the Sierra Nevada. Coiled forms of cephalopods (ammonites) were abundant and large swimming reptiles common. Their remains spread upon the sea floor became entombed in the

a Mother Lode District folio (No. 63), Geologic Atlas U. S., U. S. Geol. Survey, 1900, p. 4.

$b$ Redding folio (No. 138), Geologic Atlas U. S., U. S. Geol. Survey, 1906, p. 10.

$c$ Lindgren and Turner, in gold belt folios. 
Hosselkus limestone. On top of the limestone the dark calcareous mud of the Swearinger slate and, in the Redding region, the Brock shale were laid down over a wide stretch along the Pacific coast from California to Alaska during an epoch which, like that of the Hosselkus limestone, was free from volcanic activity.

\section{JURASSIC.}

The Triassic was closed and the Jurassic initiated by small changes of level accompanied by a recurrence of volcanic activity, but all the while most of northern California remained beneath the sea, and the unconformity between the Triassic and the Jurassic is not great. In the Taylorsville region the earliest Jurassic deposits occur in the Trail beds of fresh or brackish water origin. These are of limited extent, for at the same time in the Redding region marine deposits were in progress. In the next succeeding epoch, when the Hardgrave sandstone was deposited, the sea covered the Taylorsville region, western Nevada, and much of eastern Oregon, which continued submerged until near the close of the Jurassic.

Though they were quiescent epochs during which the Hardgrave sandstone, Thompson limestone, and Mormon sandstone were formed, the Jurassic was a period of recurrent volcanic activity, which spread the Fant and Hull meta-andesites upon the surface and furnished a source for much of the material of which the Jurassic strata of the Taylorsville region are composed.

The fauna of the Foreman beds, which is the youngest of the Jurassic in the Taylorsville region, has not yet been studied by a paleontologist in the field, but from all that is known of it thus far its discovery has not changed the order of relative age published by Professor Hyatt, ${ }^{a}$ in which he regards the Mariposa formation as younger than those found in the Taylorsville region.

The Aucella fauna in the Mariposa beds is limited in the Sierra to the lower portion of its western slope. A thick deposit of slates like those of the Mariposa has been reported by $\mathrm{King}^{b}$ in western Nevada, but no fossils have yet been found in them to confirm the correlation. The Mariposa contains many conglomerates, and according to Lindgren" was laid down in "immediate proximity of the shore line." Its absence east of the main crest in the Sierra is probably due to an uplift at the close of the Taylorsville Jurassic, excluding the sea from that region. Volcanic eruptions on the west slope continued during the Mariposa.

a Bull. Geol. Soc. Americe, vol. 5, 1894, p. 413.

$b$ U. S. Geol. Explor. 40th Parallel, vol. 1, 1878, p. 395.

$\bullet$ Colfax folio (No. (6i), Geologic Atlas U. S., U. S. Geol. Survey, 1900, p. 3. 
EARLY CRETACEOUS (SHASTA).

The Jurassic was closed and the Cretaceous initiated by a profound compression of the rocks of the Sierra Nevada, folding and crushing them and converting the finer late Jurassic sediments, the Mariposa, into slates. In the Taylorsville region the Jurassic was completely overturned and then faulted by a later movement along the plane of the Taylorsville overthrust. The vast masses, batholiths of granitic and dioritic rocks, as well as many dikes and smaller bodies of various igneous rocks, which form so large a part of the Sierra Nevada, were intruded mainly in connection with the great compression and upbuilding of the range about the beginning of the Cretaceous, and many of the older igneous rocks and sediments were converted into schists along the borders of the batholiths.

The compression, intrusion, and uplift affected not only the region of the Sierra, but also that of the Great Basin adjoining the Sierra on the east, and at that time perhaps not yet clearly differentiated.

The whole region was above the sea and was vigorously attacked by erosion. In the course of long-continued degradation during the early Cretaceous orographic prominences were removed and the surface reduced to comparatively gentle features. A great thickness of fine deposits accumulated west of the Sierra near the fortieth parallel in the Sacramento Valley. Subsidence was in progress along the coast toward the close of the early Cretaceous, and the sea gradually encroached upon the land, but a differential change of level occurred which resulted in the formation of a thick and extensive conglomerate along the present western border of the Sacramento Valley.

This change appears to have involved the lifting up of the Sierra and Great Basin region until the latter started to collapse and break away from the Sierra by the development of a remarkable series of faults, which mark their eastern limit.

South of latitude $38^{\circ} 30^{\prime}$ the displacement along the east face of the Sierra appears to have taken place chiefly along one fault line, but north of that latitude there were three principal lines of displacement. Beginning near Lake Tahoe they diverge slightly, and then, becoming approximately parallel, extend northwest with more or less continuity for over 100 miles. Lindgren has shown that these faults in the neighborhood of Lake Tahoe are older than the andesitic flows, and appear to have originated during the early Cretaceous. Much of the displacement occurred at that time, but north of the latitude of Sierra Valley the displacement was later.

\section{LATER CRETACEOUS (CHICO).}

During the deposition of the Chico the Sierra region was gradually subsiding and the sea transgressing until it beat upon the western foot of the mountains several hundred feet above the present level 
of the sea. The subsidence and transgression were greatest toward the northern end of the range, but were nowhere profound. The Chico sediments soon became fine and more or less calcareous, indicating gentle slopes upon the land approximating the condition of a peneplain. ${ }^{a}$ The Chico closed with an uplift which excluded the sea from northern California.

\section{EOCENE.}

The uplift at the opening of the Eocene, though small, was accompanied, by considerable deformation, resulting locally in a more or less distinct unconformity, but produced no striking change in the character of the marine sediments succeeding the Chico in middle California and southwestern Oregon. The valleys were deepened as a result and then widened, so that comparatively gentle slopes soon again prevailed. The landscape was one of broad and comparatively shallow valleys, whose divides preserved the gentler features of an earlier (Cretaceous) topography. The rate of disintegration became greater than that of transportation, and a mantle of residuary material rich in vein quartz accumulated upon the surface.

From the abundance of material at hand the streams became overloaded and filled their valleys. The gravels were largely quartzose and auriferous. The sand that reached the mouths of the streams was arkose. This appears to have been the condition of affairs indicated by the coaly deposits and sands which form the lower half of the main mass of auriferous gravels in the Taylorsville region.

Well toward the close of the Eocene the Sierra, in latitude $39^{\circ} 30^{\prime}$, was elevated and greatly increased the stream grade of Jura River, flowing northward, so that it contributed gravel instead of sand to its delta, and numerous bowlders were carried into its channel. The stream grades of the western slope of the range must have been increased at the same time, but according to Turner their grade was not so great as that of Jura River. That this took place in the Eocene is suggested by the fact that the flora of this early gravel epoch is similar to that of the Eocene of Oregon.

\section{MIOCENE AND PLIOCENE.}

The conditions of gravel deposition may have continued in the Jura River region from the latter portion of the Eocene through the greater portion of the Miocene and Pliocene apparently without material change. The stream continued to flow and the estuarine body of water which it entered remained covering the north end of the Sierra throughout the period, and as far as may be judged from the gravels the river grade was not changed essentially.

Before the close of the Miocene the volcanic flows from the crest of the range began. The earliest flows were of rhyolite, which fol-

a Lindgren was the first to point out this peneplain (Jour. Geology, vol. 4, 1896, p. 894). 
lowed the lines of drainage and covered the gravels about the head of Jura River. Its eruption is represented by layers of volcanic dust in the main gravel mass on Willards Creek. These were followed after an interval by flows of andesitic and basaltic lava and breccia, which completely filled the upper course of Jura River and changed its drainage. The lower course was left uncovered, but along the Diamond Mountain region and farther northwest flows issued and covered large tracts of the main gravel mass and furnished material for the later gravels formed by the waves of the bordering water body.

\section{QUATERNARY.}

About the close of the Pliocene great changes occurred in the north end of the range. With the adjoining portion of the Great Basin it was uplifted and afterward faulted so as to completely change its topography and drainage. The uplift increased toward the north, for the delta of Jura River was raised from a low altitude to an elevation of 7,000 feet- that is, to nearly as great an altitude as its source. The time of this deformation was subsequent to the volcanic eruptions of its vicinity but contemporaneous with great activity about Lassen Peak, as if the pressure in the one case was relieved by volcanic eruptions and in the other by upheaval.

The upheaval and deformation of the Jura River valley resulted in a complete change of drainage and added to the drainage of the watercourses of the western slope of the range, part of it going to Yuba River, but the greater portion to Middle and North forks of Feather River. The effect of the deformation upon drainage is illustrated in fig. 12 by a general profile along the Jura River bed, omitting the later effects of erosion. The ancient river bed descends from 7,000 feet

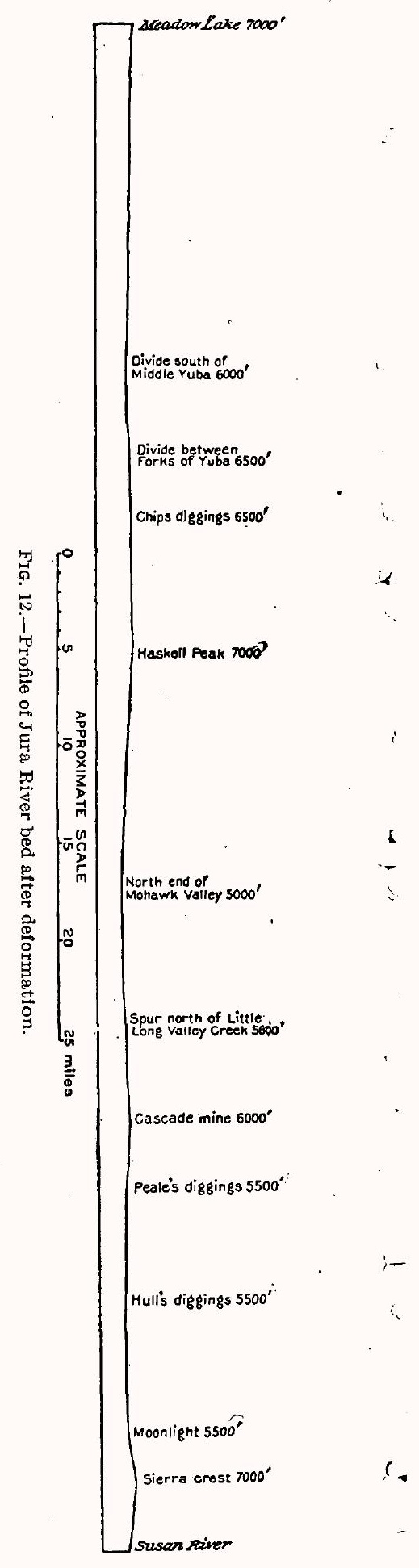


near Meadow Lake to 6,000 feet where drained by the forks of Yuba River, and rises again to 7,000 feet in Haskell Peak. Crossing Mohawk Valley fault it descends to 5,000 feet where drained by Middle Fork of Feather River, but again rises to 6,000 feet at the Cascade mine, from which there is a slight descent to Peale diggings and Moonlight drained by North Fork of Feather River. Here the gravels are decidedly lithified and arch over the eastern block of the Sierra to Susan Creek of the Great Basin region.

The deformation probably began on the east, turning the water westward, and appears to have been very gradual, permitting the forks of Feather River to maintain their courses and cut deep canyons directly across the rising crests of the range. Small temporary lakes may have been formed, but they were not extensive and were soon filled up, forming fertile valleys, of which Indian Valley is an example.

\section{ECONOMIC GEOI.GY.}

\section{HISTORY.}

During the great gold excitement in California prospectors found their way into the depths of the forest-clad mountains about Indian Valley as early as 1850 . The "Bullion ledge," a short distance northwest of Greenville, was discovered the next year and many locations followed, so that within ten years Greenville became an active mining center. Gold was the primary object of search, but the discovery of rich copper ores in 1865 led to the erection of a small furnace, which maintained a sporadic activity for four years.

Though no great mines have been developed about Indian Valley, between forty and fifty small ones have at various times contrib- uted to a total output of over $\$ 7,700,000$. The values are almost wholly in gold, with a little silver and less copper. Iron ore, coal, building stone, and mineral springs, although present, have not yet become sources of revenue. There are now many active prospects in the region, but scarcely half a dozen paying mines.

On the accompanying sectional map of the Indian Valley region (P1. V) Mr. Arthur Keddie located the surveyed mining claims of the following list in 1904, and I have added references to the prospects, mines, and ores. The claims are more or less distinctly grouped in two belts, the Crescent Mills belt and the Genesee belt. 
List of mining claims in Indian Valley.

T. 25 N., Rs. 9, 10, and 11 E.:

1. Bridge Q. M.

2. Shoo Fly Q. M.

3. Golden Age Q. M.

4. Golden Era Q. M.

5. Rising Sun Q. M.

6. Golden Dawn Q. M.

7. Golden Coin Q. M.

8. Greenwood Q. M.

9. Jennie Veamans Q. M.

10. Kismet Q. M.

11. Mirabile Visu Q. M.

12. Plumas Grizzly Q. M.

13. Queenie Q. M.

14. Fiesta De Oro Q. M.

15. Camp Compton Q. M.

16. Camille Q. M.

17. Hayward Q. M.

18. Rock Taylor Q. M.'

19. King Solomon Annex Q. M.

20. Grand Prize Annex Q. M.

21. Genesee Q. M.

22. Italia Q. M.

23. Queen of Sheba Q. M.

24. Lodi Q. M.

25. Pilot Q. M.

26. Barney Tutt Q. M.

27: Green Ledge Q. M.

28. Queen of Genesee Q. M.

29. Copper Queen Q. M.

30. Centennial Q. M.

31. Centennial South Ex. Q. M.

32. Black Bear Q. M.

33. Brown Bear Q. M.

34. Grizzly Bear Q. M.

35. Polar Bear Q. M.

36. Cinnamon Bear Q. M.

37. Grizzly Q. M.

38. Bear Q. M.

39. Plano Q. M.

40. Peacock Q. M.

41. Ingo $\mathrm{Q}$. $\mathrm{M}$.

42. Copper Bell Q. M.

43. Copper Queen Q. M.

44. Morning Star Q. M.

45. Limbo Q. M.

46. Evening Star Q. M.

47. Reno Q. M.

48. Fossil Q. M.

49. Reward Q. M.

50. Beckwith Q. M.
T. 26 N., Rs. 9 and 10 E.:

1. Centennial Q. M.

2. New York P. C.

3. Kennebec Q. M.

4. Plow Boy Q. M.

5. New York Q. M.

6. Antelope Q. M.

7. Hong Kong Q. M.

8. Dewey Q. M.

9. Johnny Bull Q. M.

10. Bird Q. M.

11. Summit Q. M.

12. W. Pacific Q. M.

13. Pacific Q. M.

14. Drury Q. M.

15. Arctic Q. M.

16. Phoenix Q. M.

17. East Phoenix Q. M.

18. Sunrise Q. M.

19. Sunset $Q$. M.

20. Arcadian Q. M.

21. Brooklyn Q. M.

22. Comstock Q. M.

23. Dominion Q. M.

24. Union Q. M.

25. Blaine Q. M.

26. Indian Valley Q. M.

27. Arctic Q. M.

28. Summit Q. M.

29. Atlantic Q. M.

30. Hibernia Q. M.

31. Pacific Q. M.

32. Crown Point Q. M.

33. Prospect Q. M.

34. Standart Q. M.

35. Brewster Q. M.

36. Valentine Q. M.

37. Robinson Q. M.

38. Eclipse Q. M.

39. Altona Q. M.

40. Emerald Q. M.

41. Arid Q. M.

42. Lizzie Q. M.

43. Jackson Q. M.

44. Tunnel Q. M.

45. Monroe Q. M.

46. Empire Q. M.

47. Ruby Q. M.

48. Brilliant Q. M. ${ }^{\circ}$

49. North Star Q. M.

50. Susan Jane Q. M. 


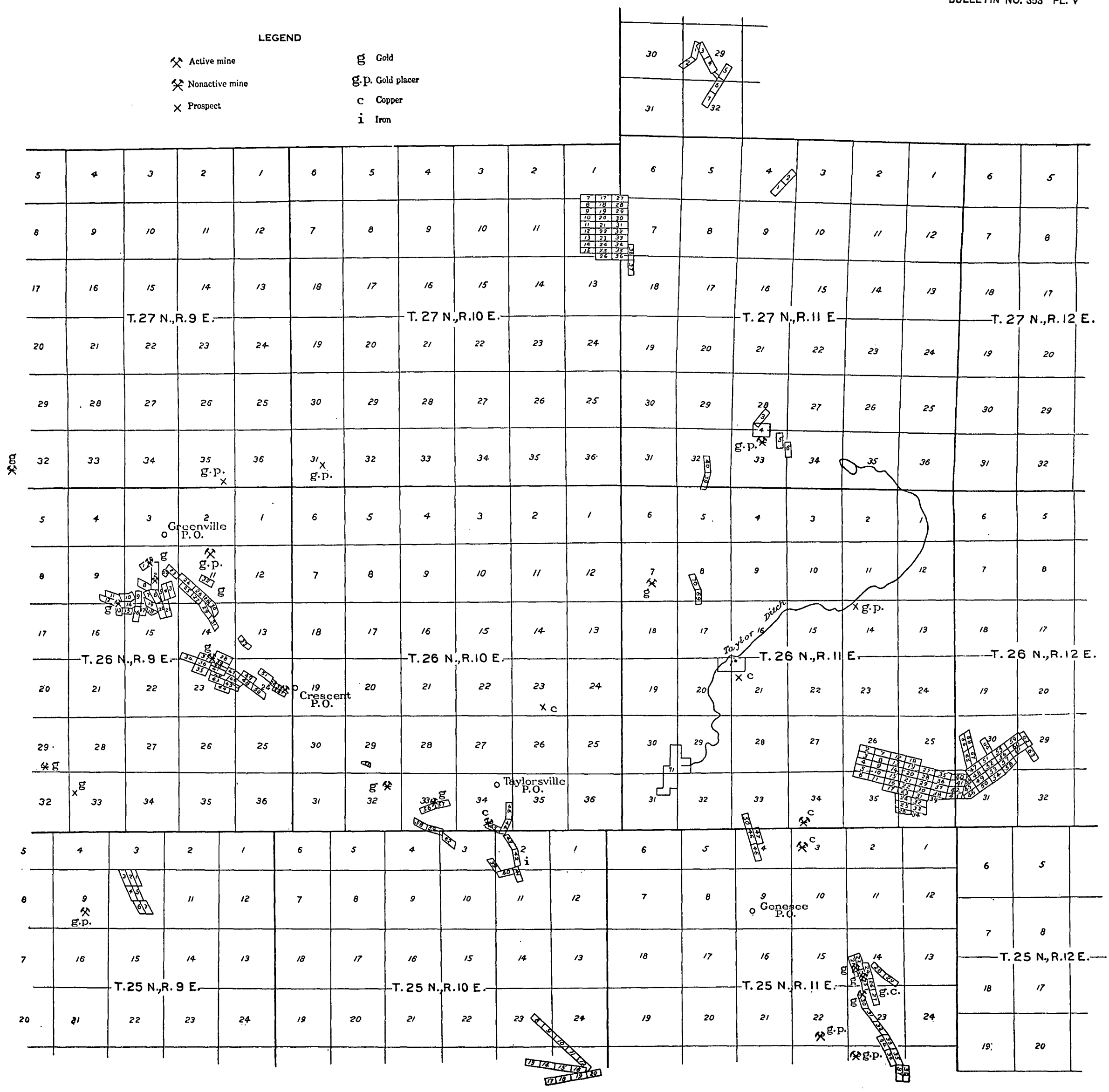


T. 26 N., Rs. 9 and 10 E.-Continued.

51. Miller Q. M.

52. Cole Q. M.

53. Crescent Q. M.

54. Pet Q. M.

55. Plumas Q. M.

56. California No. 1 Q. M.

57. California No. 3 Q. M.

58. California No. 4 Q. M.

59. California No. 2 Q. M.

60. Palmyra Q. M.

T. 26 N., Rs. 11 and 12 E.:

1. Hull P. C.

2. Hornfel Q. M.

3. Jura Q. M.

4. Laura Q. M.

5. Lucy Q. M.

6. Omega Q. M.

7. Glass Q. M.

8. Main Q. M.

9. Wisconsin Q. M.

10. Climax Q. M.

11. Index Q. M.

12. Jupiter Q. M.

13. Mars Q. M.

14. Signal Q. M.

15. Cherokee Q. M.

16. Hopeful Q. M.

17. Gage Q. M.

18. Venus Q. M.

19. Summit Q. M.

20. Empire Q. M.

21. Locust Q. M.

22. Wonder Q. M.

23. Homestake Q. M.

24. McKinley Q. M.

25. Lincoln Q. M.

26. Garfield Q. M.

27. Queen Q. M.

28. Hammoth Q. M.

29. Williams Q. M.

30. Jessie Q. M.

31. Wide Awake Q. M.

32. Roosevelt Q. M.

33. Washington Q. M.

34. Perkins Q. M.

35. Butte Q. M.

36. Nellie Q. M.

37. Timey Q. M.

38. Rose Q. M.

39. Slim Jim Q. M.

40. Clipper Q. M.

41. Congress $\mathrm{Q}$. $M$.
T. 26 N., Rs. 11 and 12 E.-Continued.

42. Nome Q. M.

43. Isabelle Q. M.

44. Libby Q. M.

45. Emma Q. M.

46. Molly Q. M.

47. Cooksey Q. M.

48. Chico Q. M.

49. Duncan Q. M.

50. Dome Q. M.

51. Calnan Q. M.

5\%. Carbonate Q. M.

53. Chondrodite Q. M.

54. Castle Q. M.

55. Jennie Q. M.

56. Cascade Q. M.

57. Cabaritic Q. M.

58. Columbine Q. M.

59. Clasper Q. M.

60. Phonolite Q. M.

61. Colorado Q. M.

62. Crown Q. M.

63. Bond Q. M.

64. Outcrop Q. M.

65. Arizona Q. M.

66. Columbia Q. M.

67. Lyddite Q. M.

68. Jeanette Q. M.

69. Bonanza Q. M.

70. Bonanźa No. 2 Q. M.

71. Taylor Diggings Q. M.

T. 27 N., Rs. 10 and 11 E.:

1. Engles Copper Mine No. 3.

2. Engles Copper Mine No. 2.

3. Lucky S No. 2 Q. M.

4. Cadmus P. C.

5. Lucky S Q. M.

6. Sheep Herder Q. M.

7. Moonlight Q. M.

8. Wasp Q. M.

9. Grant Q. M.

10. Hulsman Q. M.

11. Sherman Q. M.

12. Oregon Q. M.

13. Olympia Q. M.

14. Davenport Q. M.

15. Edward Q. M.

17. Sidehill Q. M.

18. Sperm Q. M.

19. Oak Q. M.

20. Shough Q. M.

21. Gentle Annie Q. M.

22. Cabin Q. M. 
T. 27 N., Rs. 10 and 11 E.-Continued:

23. Ridge $\mathrm{Q}$. $\mathrm{M}$.

24. No Wonder Q. M

25. Dexter Q. M.

26. Live Oak Q. M.

27. Fair View Q. M.

28. Stone Point Q. M.

29. Fritz Q. M.

30. Big Spring Q. M.

31. Big Boo Q. M.

32. Belmont Q. M.

33. Claremont Q. M.

34. Vermont Q. M.

35. Palo Cedar Q. M.
T. 27 N., Rs. 10 and 11 E.-Continued.

36. Grant Q. M.

37. Crystal Q. M.

38. Chaune Q. M.

39. Indian Valley Silver Mine.

40. Indian Valley Silver Mine.

T. 28 N., R. 11 E.:

1. North Star Q. M.

2. St. Paul Q. M.

3. Red Ocher Q. M.

4. Sunset Q. M.

5. Talbott Q. M.

6. Jackson Q. M.

7. Yellow Ocher Q. M.

\section{DEVELOPMENT IN THE CRESCENT MILLS BELT.}

The principal producing mines of the region have been the Crescent Mills, Green Mountain, Indian Valley, and McGill-Standart, all of which, with many others of less importance, lie in the Crescent Mills mining belt, which extends from the neighborhood of Taylorsville north $50^{\circ}$ west through the Crescent Mills and Greenville districts to Wolf Creek, a distance of about 15 miles, with a width of a little over a mile. In the Crescent Mills belt in October, 1904, there were but 2 producing mines, with 1 quartz mill and 2 arrastres.

\section{DEVELOPMENT IN THE GENESEE BELT.}

The most continuous activity of the region has been along Wards Creek, on the border of Genesee Valley, where the Gruss mine has been in operation for over twenty years. Near by is the Five Bear mine, and across Genesee Valley is the Cosmopolitan, from which most of the ore was obtained years ago for the Coppertown furnace. Beyond are the Regal, Engel, and finally, in Lights Canyon, the Superior mine, where a body of bornite and chalcopyrite approximately 60 feet long, 40 feet wide, and 3 feet thick has been removed. These mines and several smaller ones lie in the Genesee mining belt, which extends from Wards Creek north $22^{\circ}$ west to Lights Canyon, a distance of about 15 miles. While conservative estimates place the total production of the Crescent Mills belt at $\$ 6,650,000$, that of the Genesee belt has been estimated at $\$ 450,000$. In 1904 in the Genesee belt there were 5 mines active, with 2 stamp mills and 3 arrastres.

\section{GEOLOGY OF CRESCENT MILLS BELT OF MINES.}

The Crescent Mills mining belt has in it two long, narrow masses of granodiorite, one, southwest of Taylorsville, cutting the Paleozoic sediments; the other, between Crescent Mills and Greenville, cutting the quartz porphyries of that district. The metalliferous deposits are confined chiefly, but not wholly, to the igneous rocks, and in none 
of the cases examined are they definite contact deposits such as occur in a portion of the Genesee belt. The deposits throughout the Crescent Mills belt are in more or less well-defined quartz veins running generally parallel to the course of the belt, but in a few cases there are small veins nearly at right angles to the others. The ore is auriferous pyrite, sometimes in small bodies but generally disseminated in the narrow strip of sheared rock of the partially formed vein in which there is usually some quartz. The pyrite is nearly always changed to limonite, setting the gold free and staining the indistinct vein as well as its walls. One of the best defined and most complete quartz veins of the Crescent Mills belt occurs in the Premium mine. It is vertical, about 2 feet in thickness, and cuts granodiorite.

In the Green Mountain mine one subordinate vein carries a small amount of chalcopyrite, but in general copper is absent in the belt except at the old Pettinger mine, two-thirds of a mile south of Taylorsville, where a small imperfect vein in the Taylorsville slate is impregnated with carbonates of copper, sometimes blue but generally green.

An exceptional deposit for the Crescent Mills belt, and indeed for the whole region, is a mass of pyrrhotite a mile and a half nearly south of Taylorsville. It lies in a narrow strip of sheared sandstone running north and south near the horizon of the Montgomery limestone, but the largest body, about 10 feet in thickness, is at a point where the sheared sediments end against serpentine. The pyrrhotite was tested for nickel by'Hillebrand, but none was found.

\section{GEOLOGY OF THE GENESEE BELT OF MINES.}

The Genesee mining belt follows approximately the northeastern limit of the Mesozoic and Paleozoic sediments where they come in contact with the granodiorite and the Kettle meta-andesite. The deposits are variable; some are more or less complete veins following narrow belts along which the rock has been crushed and sheared; others follow the line of contact bounding the granodiorite. In some deposits the ore is auriferous quartz and limonite, but in others the ore is chiefly bornite, chalcopyrite, chalcocite, or copper carbonates. Quartz is the most common gangue mineral, but in one case barite appears and in another a green mineral like actinolite.

The Gruss mine, on Wards Creek, is on both sides of the contact between the Kettle meta-andesite and slaty shale of the Robinson formation. In the shale the partially formed veins follow narrow shear zones, in which there is some auriferous quartz associated with limonite that deeply. stains the richest portions of the crushed mass. The adjacent meta-andesite is often decidedly slaty and its ores are chiefly chalcopyrite or bornite, with copper carbonates near the surface. 
The rocks along the contact are much sheared and apparently somewhat richer than those on either side. No characteristic contact minerals were observed to suggest that ores in this case were originally contact deposits modified after the development of the slaty cleavage.

The Five Bear mine in the Robinson slate is much like the Gruss, but the Green Ledge, Pilot, and others in the Kettle meta-andesite have small veins of quartz with bornite and some chalcocite. The veins are generally less than 5 inches in thickness.

The Cosmopolitan mine is on the contact of the granodiorite with the Hosselkus limestone and Swearinger slate. The ore is bornite and chalcopyrite, forming solid bodies up to 15 feet in thickness, with greater dimensions in the plane of contact, along which other smaller bodies of the same ore occur. On the surface the contact is marked by masses of garnet and epidote which were not seen beneath, but in the Duncan mine the garnet and epidote are associated with the ore.

The Bluebell mine is in the Hosselkus limestone near the contact, and from one of its shafts some tons of carbonate of copper have been brought up in connection with cave breccia, suggesting a secondary deposit within the limestone. A small vein of barite occurs in altered andesites at the old Indian Valley silver mine, about a mile southwest of Lucky S mine, and locally contains traces of copper ore.

Near the northwestern end of the Genesee belt is the Superior mine, in which the gangue of the bornite is a green fibrous mineral like actinolite. A number of parallel vertical veins of this mineral are well exposed in the open cut and contain disseminated particles and nodules of bornite. The larger ore bodies are free from gangue. The wall rock, which is fine-grained granodiorite, is the same on both sides and the veins are sharply defined.

\section{AURIFEROUS GRAVELS.}

Development.--In the Taylorsville region modern stream beds have been mined in Lights Canyon and on Indian Creek above Flournoy as well as below Arlington Bridge. The total yield of these modern gravels is near $\$ 10,000$ annually.

About the head of Lights Creek, . Mountain Meadows, and Moonlight ancient gravels have been mined írregularly in a small way for over twenty years, and the total yield, according to a conservative estimate, is nearly $\$ 500,000$.

Kinds of gravel.-The auriferous gravels which have been mined about Indian Valley are of two kinds-(1) the gravels of the present stream beds and terraces near them, and (2) the gravels of ancient streams, or high gravels like those of the Taylor diggings on the mountain summits far above the streams of to-day, composed generally of well-rounded waterworn gravel. 
Auriferous gravels of present streams.-The gravels of the present stream beds and their terraces have been mined at a number of points in the region, especially along the upper courses of the streams where the grade is sufficient to prevent the deposition of finer material such as fills Indian Valley proper, North Arm, and Genesee Valley.

Indian Creek heads about Diamond Mountain and Thompson Peak on the eastern crest of the Sierra Nevada in a large area of high gravels, and has doubtless concentrated whatever gold there may have been in the small amount of gravel which has been washed away. Judging, however, from present activity and recent output, the part of Indian Creek east of Genesee Valley does not hold out especially promising prospects, but this can not be taken as conclusive. The record of a greater activity years ago is not available.

Lower down on Indian Creek beyond Indian Valley, near Shoo Fly Bridge, gravel on one of the benches is worked by water taken out at the narrows and having a fall of nearly 100 feet. The excavation is but little above the stream level and has been carried on in a small way by R. Martin for a number of years. Within this portion of the quadrangle there has been no hydraulic mining for several years, but a few miles farther west, on Soda Creek, Rush Creek, and North Fork of Feather River, hydraulic and placer mining have been carried on extensively and profitably for many years.

Placer mining has been carried on along the upper course of Wolf Creek, Cooks Canyon, and several other small streams, but the most effective and persistent efforts have been made on Lights Creek and Little Grizzly Creek, just beyond the limit of the Indian Valley special quadrangle.

On Lights Creek, Ruffa, the Chatfield Brothers, and Peters work for several months every year with water under about 100 feet pressure and one or two giants each, but the amount of débris removed. is small.

On Little Grizzly Creek, one of the strongest streams of the region, the work is done on a somewhat larger scale during the summer in the present stream bed, where large bowlders are encountered. In the winter the terraces from 100 to 200 feet above the stream are worked, and in the same region at a much greater elevation is the Cascade hydraulic mine described by Turner in the Downieville folio.

The entire annual yield of the placer mines within and bordering on the Indian Valley quadrangle is probably somewhat less than $\$ 10,000$.

Auriferous gravels of aneient streams.-The distribution of the auriferous gravels of ancient streams in the Taylorsville region is fully shown on Pls. II and III. They are mined at a number of points, especially near the border of Moonlight, at the southeastern head of Mountain Meadows, and in Cooks Canyon, where Evans, Davis, Smith, and others have operated a month or more nearly 
every year for twenty years, but the work is confined to the lower edges of the gravels. which range from an altitude of 5,000 feet on the west and north to 7,000 feet at the southeast about Diamond Mountain, on the crest of the Sierra Nevada. As the gravels rest upon the summits, it is almost impossible to obtain water in quantities sufficient for ordinary mining even a few days or weeks each year.

In connection with the ancient auriferous gravels certain residual deposits should be noticed in which the débris was not waterworn nor at any time in any proper sense a part of a stream bed. The débris is simply the material derived from the disintegration of the bed rock in place. Where rocks contain veins rich in native gold, the gold liberated by disintegration lodges near by unless removed by erosion.

A third of a mile northwest of Round Valley Reservoir :a placer mine on the gentle slope toward the reservoir is said upon good authority to have yielded $\$ 150,000$ some years ago. The placer mine covered the northern extension of the veins from the StandartMcGill mine on the adjacent slope, and its richness is to be attributed to the residual material from the veins.

Another example of the same kind was in the placer mine of Mr. Davis, who washed the soil from the slate hill where the Gruss mine of Genesee is now located, and where auriferous veins were discovered which yielded about $\$ 25,000$.

Several years ago, on the western slope of the Moonlight branch of West Fork of Lights Creek, a small but, rich placer was discovered and worked for a little while. The material, though largely residual, contains some gravel and lies close to the bottom border of the great body of gravel about Moonlight. The gravel of that region rests on residual material, and it is possible that the local richness is derived from the gravels removed in the process of erosion.

\section{DEPOSITS OF IRON ORE.}

Although iron is not mined in the Indian Valley region, there are several deposits of sufficient importance to deserve mention, and at some future time they may be utilized. The most promising is at the southern border of Moonlight, in a broad valley at an elevation of 5,600 feet, 11 miles north of Taylorsville, where an area of about 2 acres occurs having red soil strewn with black chunks of hematite and with some magnetite. Some of the fragments are 2 feet in diameter. No excavations have been made, but the ore on the surface and the color of the soil indicate a considerable body of iron ore beneath.

About a third of a mile west of this locality a small opening exposes a mass of hematite, in part breccia, over 4 feet thick. It strikes 
nearly east and west approximately in line with the area noted above and dips about $45^{\circ}$ to the south.

A few degrees west of south from the 2-acre area there are a number of small pits and fragments of iron ore in line to an old opening made by Hulsman, which exposes a veinlike mass of magnetite and hematite. Some of the fragments have magnetic polarity; others are not magnetic at all. The opening is only about 10 feet deep and the ore is said to run out at that depth. It is possible that there are two lines of iron-ore deposits, one nearly north and south and the other approximately at right angles. The two lines appear to meet in the 2-acre area.

Red chert is exposed at a number of points in the Indian Valley region, and it is not yet known to how many horizons it may belong. With it is always associated more or less hematite, so that the specimens frequently resemble the jasper iron ore of the famous Marquette region in Michigan.

One of the best outcrops of this kind is in the summit of Houghs Peak, but the amount of hematite exposed is always small.

An exceptional and perhaps the most interesting mineral deposit rich in iron in the Taylorsville region is the mass of pyrrhotite a mile and a half south of Taylorsville. It is briefly described on page 115, in connection with the Crescent Mills belt.

\section{DEPOSITS OF COAL.}

In the Taylor gravel diggings a few years ago a bed of coal was laid bare and at the time attracted attention. The bed is about 5 feet thick, lies nearly flat beneath the auriferous gravels to which it belongs, and rests directly upon the upturned edges of Jurassic sandstone. On the north side it is cut off by a fault and ends abruptly against the sandstone. Southward beneath the gravel its extent is unknown, but can not be great. About a ton of coal has been mined - for blacksmithing, but no definite local demand has yet resulted.

Traces of coal were observed also east of Moonlight, near the base of the great deposit of auriferous gravel and sand, and mark an epoch of very gentle slope at the beginning of the auriferous gravel period. None of the coal is of economic value.

\section{MINERAL SPRINGS.}

Among the mineral resources of the Indian Valley region are several mineral springs on the main road from Taylorsville to Quincy. A few hundred yards northeast of the Arlington Bridge is an iron spring of moderately cool water containing some free carbon dioxide and carbonate of lime, so that it forms a mound of calcareous tufa deeply stained or completely covered with oxide of iron. Its flow is about 4 quarts per minute, and it is recommended by the people of the vicinity who have used it as good for those having dyspepsia. 
Between Shoo Fly Bridge and Clear Creek, on the Quincy road, are two soda springs. The one near Shoo Fly is clear and cool and rich in carbonic acid, refreshing many a passing traveler; the other is less highly carbonated and has more iron. Both have deposited large masses of calcareous tufa on the steep slopes. Near the Shoo Fly Bridge the tufa looks like an ordinary limestone.

The hot spring near Greenville, said to be locally used for bathing in case of rheumatism, was not examined.

\section{RÉSUMÉ.}

The topographic elements of the north end of the Sierra are three fault blocks with prominent escarpments to the east and long, gentle slopes to valleys along their western borders.

There are eighteen sedimentary formations in the Taylorsville region, of which six are Paleozoic, nine Mesozoic, one Tertiary, and two Quaternary. The oldest is Silurian quartzite with some lentils of slate and of limestone, followed in regular order by Devonian slate and a great succession of Carboniferous strata that for convenient consideration may be separated into four formations-Arlington, Shoo Fly, Peale, and Robinson-all of which are characterized more or less fully by fossils. The first three embrace a large part of the strata which form the Calaveras of the gold belt folios.

The Triassic has two formations in the Taylorsville region, one of limestone, the other chiefly of slate, but the Pit formation and volcanic rocks at the base of the Triassic, so extensively developed in the Redding region, do not appear about Taylorsville, where their horizon is represented apparently by a marked unconformity.

The Jurassic is unconformable on the Triassic and is made up of a succession of seven formations, which are characterized for the most part by abundant faunas.

Of the igneous rocks metarhyolite is the oldest. Its effusion probably dates from early in the Silurian, certainly earlier than the time of the Grizzly formation. Volcanoes were especially active at intervals in the Carboniferous, giving rise to three extensive masses of meta-andesite. They were active also in the early Jurassic.

About the close of the Jurassic, in connection with the compression and deformation of the rocks of the Sierra Nevada,o the greatest eruptive masses of the region were formed. The rocks differ markedly in type from those of earlier date. While the earlier ones were prevailingly volcanics, effusive, those at the close of the Jurassic were intrusive, some of them coarse granular, like diorite and peridotite, while others were finer grained, forming dikes.

The great structural features developed in the Taylorsville region during the orogenic epoch at the close of the Jurassic are the Grizzly 
Mountains anticline, the Mount Jura syncline, and the Taylorsville fault. The Jurassic strata were completely overturned toward the east and then faulted by an overthrust-the Taylorsville fault-in the same direction.

Following the epoch of igneous intrusion and mountain building which made the Sierra Nevada a prominent range came one of longcontinued erosion, for the Sierra Nevada has ever since been dry land, exposed to vigorous degradation. The earlier records of this degradation are not yet clearly made out, but the later ones are contained in the subsequent Cretaceous and Tertiary sediments of the Sacramento Valley.

Though the late Cretaceous sediments lie upon the western base of the Sierra Nevada, they do not form a considerable part of the range. The first post-Jurassic rocks involved in the main body of the northern end of the range are the earlier auriferous gravels.

The long-continued erosion during the Cretaceous, with comparatively little upheaval, reduced the bold orographic features formed at the close of the Jurassic to gentle slopes and gave rise to what Lindgren has designated the Cretaceous peneplain. A small differential uplift of the range incised the old peneplain. In the course of time the valleys were widened and filled with auriferous gravel and finally covered by volcanic flows.

The prevolcanic portion of the auriferous-gravel period is represented on the north end of the range by 1,000 feet of deposits, of which the lower half is chiefly residual sand. This sand originated in the gentle slopes of the region when disintegration exceeded transportation, and the auriferous quartz veins were set free and gradually concentrated by the removal of fine material until the rich quartz gravels of the earliest stream beds now preserved were formed. The prevolcanic portion of the auriferous-gravel period was long, and the drainage of the Taylorsville region at that time was northward, into the water body which then filled the Lassen Peak depression between the Sierra Nevada and the Klamath Mountains and received sediments of the entire period.

The flora of the early auriferous gravels of the Taylorsville region has a number of forms that occur not only in the earlier gravels of the western slope of the Sierra Nevada but also with marine shells of Eocene age in Oregon and support the suggestion made by Lindgren that the earliest prevolcanic auriferous gravels are at least in part of Eocene age.

The condition of low relief prevailed, with but slight changes of level, to the close of the Tertiary, when the Quaternary was initiated by great topographic changes, the consequences of the great uplifting and faulting of the range. 



\section{INDEX.}

A. Page.

Acer Bendirei

Acrochordiceras........................

Acrostichites

brevipennis.

princeps............................

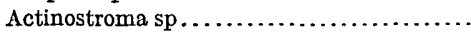

Alectryonia sp.

Algæ.

Alluvium, occurrence and character of

Alnus Kefersteinii......................

Amboccelia planiconvexa.

American River, rocks on................ $57-58$

American Valley fault, description of....... 102

Ammonites.......................... $\quad 56$

Ammonitinæ....................... 46,49

Amplexus......................... $\quad 57$

Andesite, occurrence and character of ...... 93-94

relation of, to other rocks

Indesitic breccia, occurrence and character of.

Anomia sp

Arcestes.

bicarinati .........................

galeati

sublabiati.

tornati

Aralia angustiloba......................

lasseniana.

Arkose sands, occurrence and character of ... 72

Arlington Bridge, rocks near............. 93 springs near...................... 119-120

Arlington formation, fossils and age......... 22 occurrence and character of............ 20-22 relation of, to other formations.... $22,23,84,90$

Asplenium Wegmanni................... 75

Astarte............................... 56

Astrea geminata......................... 52

Atractites ............................ 31

Aucella ................................ 60

erringtoni........................... 60 piochi.............................. 60

Aulopora sp.......................... 27

Auriferous gravels, age of................ $76-78$ classification of................. $72-74 \quad 116-118$ development of..................... 116

fossils of ....................... 74-76

occurrence and character of ........... 60-72

period of, topography of............... 78-79

Aviculipecten interlineatus................. $\quad 27$ sp.
Badiolites eryx .......................... 31

Balatonites............................ $3 \mathrm{~L}$

waageni. .......................... 31

Basalt, occurrence and character of ........ 95-97

Belemnites........................... 52,56

breviformis........................ 47

sp............................... 47,60

Bicknell sandstone, fossils and age of ....... 49-50

occurrence and character of............ 48-49

relation of, to other formations........ 50,52

Bluebell mine, description of............. 116

\section{c.}

Calaveras group, occurrence and character of. See also Arlington formation; Shoo Fly formation; Peale formation.

Cambrian time, events in............... 194

Campophyllum sp..................... 27

Camptonectes bellistriatus................ 52

Carboniferous igneous rocks, occurrence and character of. See Taylor, Kettle, and Reeve, meta-andesitc.

Carboniferous sedimentary rocks, occurrence and character of ................

See also Calaveras group; Robinson formation.

Carboniferous time, events in........... 105-106

Cardium sp............................ 60

Cascade mine, gravels in ................ 62-63

Cedar Creek, gravels on ................... 63

Chemnitzia......................... 50,52

athleta............................ 50,52

sp................................. 50

Cheney Creek, rocks near................. 94

Chico time, events in................... 108-109

Chips diggings, gravel of................. 63

Chonetes sp............................ 28

Cidaris................................ 39

sp................................ 40

Cinnamomum polymorphum...............

Scheuchzeri....................... 75

Coal, occurrence and character of .......... 119

Colfax, rocks near..................... 59

Conglomerate, figure showing............. 21 occurrence and character of............. 21

Conifer.............................. 55

Cooks Canyon, gold in................... 117

Copper, mining of ..................... 111,115

Coral................................ 27

Cosmopolitan mine, description of......... 116

Crania................................ 28 
Page.

Crescent Mills, geology near. mining near

rocks near.

Cretaceous rocks. Sec Serpentine.

Cretaceous time, events in............. 108-109 Crinoid ....................... 16,25,27,28

Crystal Lake, rocks near. . . . . . . . . . . . . 20 20-21 rocks near, figure showing.......... 21

Ctenostreon....................... 39,46 pectiniformis

sp.......................... 40,47

Curtice, Cooper, fossils collected by ..........

Curtice, Cooper, and Stanton, T. W., fossils collected by

Cyathophyllum sp.

Cystodictya sp.

\section{D.}

Daonella............................ 57,58

Devonian rocks, occurrence and character of. 13 See also Taylorsville formation.

Devonian time, events in.

Diamond Mountain, gravel of . . . . . . . . . . . rocks of . . . . . . . . . . . . . . . . . section of, figure showing shore terraces of, gravel of.

figure showing.................. 70

Diamond Mountain block, description of... . 9-11

Dielasma sp........................... $\quad 27$

Dikes, occurrence and character of......... 90-92 relation of, to other rocks...............

Diorite dikes, occurrence and character of.... 90,92

Diphyphyllum........................ 57

Drainage, description of................ 12-13

Drainage, ancient, description of.......... $63-66$

E.

Economic geology, description of .

$111-120$

Edmanton, fossils from.

Edmondia sp. ...........................

Effusive rocks. See Metarhyolite; Metaandesite.

Entolium.

$39 ; 46$

costatum......................... 50

meeki................................ 39, 40

Eocene time, events in................. 109

Equisetum munsteri . . . . . . . . . . . . . . . $\quad 55$

Escarpments, description of .............10,11-12

Estheria............................ 36

Eumicrotis............................ 60

Evans Peak, rocks on .............. 24,54-55,57 rocks on, sections of, figures showing... 54

\section{F.}

Fagus Antipofii..........................

Fant meta-andesite, age of ............... occurrence and character of.............. relation of, to other rocks.

Favosites. . ........... 17

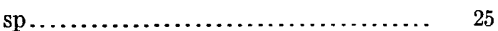

Feather River, drainage by .............. 12-13 gold on............................ 117

Fenestella sp......................... $\quad 27$

Ficus asiminæfolia...................... microphylla......................... 75 shastensis........................... 75 tilixfolia.

\section{6}

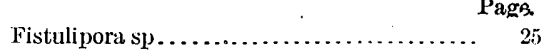

Five Bear mine, description of .......... 116

Folsom, rocks near................ $\quad 59$

Fontaine, W. M., fossils determined by..... $\quad-55$

Foreman formation, fossils and age of. . . . . . 55, 59 occurrence and character of........... 53-55 relation of, to other formations.. $56-57,85,88,91$ Foremans Ravine, rocks in ......... 25,51,57,94 Fossils. See particular formations.

Fusulina....................... 25 elongata...................... 27 sp........................... 27

G.

Genesee Valley, description of ........... 10

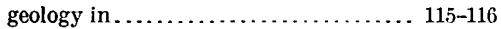

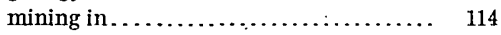
rocks in and near.................. 26 ,

$27,32,33,35,52,84,85,86,89-90$

section near, figure showing . . . . . . . . . 29

Geography, description of . . . . . . . . . . $7-8$

Geologic history, outline of. ........ 8-9, 104-111

Geology, description of . ........... 8-9, 13-104

Geology, economic, description of . . . . . . 111-120

Gervillia .......................... 39 aviculoides..................... 47 gigantea...................... 40 lanceolata.................... 47 linearis....................... 40 sp.......................... 47

Geyerella........................... 28 Girty, G. H., fossils determined by ... . 22, 25, 27, 28 Glacial moraines, occurrence and character of 80 Gleichenia......................... $\quad 55$

Gleichenopsis.................... $\quad 55$

Glossopteris........................ 55

Glyphea.......................... 39 punctata....................... 40 solitaria....................... 40 Gold, mining of.................. 111, 115-118 yield of $\ldots \ldots \ldots \ldots \ldots \ldots \ldots \ldots \ldots \ldots \ldots . \ldots \ldots$

Gold Run, gravels on................. 68-69

Goniomya v-scripta................... $\quad 39$ sp......................... 40

Goodhue, G. H., fossils collected by ........ $\quad 28$

Grammoceras leurum.................. 47 toarcense..................... 47 sp............................. 47

Granodiorite, occurrence and character of . . 8 89-90 relation of, to other rocks.......... 22,36,90

figure showing................. 29

Gravels. See Auriferous gravels.

Green Mountain mine, description of........ 115

Greenville, dikes near.................. . 90-91 gravels near........................ 79 mining near.................... 111 rocks near.................. 18,90,92 spring near....................... 120

Grizzly formation, fossils of . . . . . . . . . 15, 16 occurrence and character of......... 13, 14-16 relation of, to other formations........ 15, 19

flgure showing................. 15

Grizzly Mountain anticline............... 98

Grizzly Mountain belt, structure of......... 98 Grizzly Mountain block, description of...... 11-12 Grizzly Mountains, rocks of.............. 16, $19,30-31,38,42,45,82,87,88,89$ (iruss mine, description of.............. 115 
Gryphxa bononiformis curtici.

H.

Halysites catenulatus

Hardgrave sandstone, fossils and age. occurrence and character of............. 37-39 relations of, to other formations ........40-41, $43,48,87-88,91$

Haskell Peak, gravels on................. 63,64

Heliolites............................. 16 elegans.............................. 17

interstinctus........................ 17

Finchman Ravine, rocks in............. 24, $38,39,45,49,51,53,56,91$

Hinchman sandstone, fossils and age ........ 52,59 occurrence and character of............ 51 relation of, to other formations....... 52,56-57

Historical geology, outline of.............. 8-9

Honey Lake, drainage to.................... 12

Honey Lake fault, description of.......... 10!-102

Honey Lake quadrangle, topographic and geologic map of.............. Pocket

Hornfels Point, rocks of................ 35, 85, 93

Hosselkus, rocks near.................. 24,25

Hosselkus Creek, rocks on and near. . 26, 30, 35, 85, 94

Hossel kus limestone, fossils and age of........ 31-32 occurrence and character of............ 30-31 relation of, to other formations.. $30,32,33-34,36$ figure showing................... 29, 48

Hot Springs Peak, rock of.

Houghs Creek, rocks on. $19,22,90$

Houghs Peak, iron ore on. ... 119 rocks near.

$20,22,83-84$

Hull diggings, gravels of. $61-62$

ITull fault, description of

H.Iull meta-andesite, age of of.................. 88 occurrence and character of............. 88 relation of, to other rocks.

Huntington, rocks near

Hyatt, Alpheus, fossils determined by...... 31 , on Nevada basin rocks

Igneous rocks, description of $80-97$

Indian Creek, drainage by

$12,13,117$ gold on.

$116-117$

Indian Valley, description of iron ore in

10-11

mining in ..................111-114

rocks in and near........ 16, 23, 83, 84, 86,93,97

Indian Valley fanlt, description of.......... 103-104

Indian Valley quadrangle, topographic and geologic map of. ............ Pocket.

Ingalls Peak, rocks of . $. \ldots \ldots \ldots \ldots \ldots \ldots \ldots . .35$

Inoceramus............................. 47

Intrusive rocks. See Granodiorite; Serpentine; Pyroxenite; Dikes.

Ione formation, fossils of .................. occurrence and character of ..............

Iron ore, occurrence and character of . . . . . . 118-119

Juglans Billinica. ...................... californica.......................... egregia. rugosa.
Jura River, gravels of . .......................

history of ....................... 110-111

profile of, figure showing.............

source and course of . . . . . . . . . . $63-655,78$

Jurassic igneous rocks. See Fant meta-andesite; Hull meta-andesite; Serpentine.

Jurassic sedimentary rocks, occurrence and character of . ........... 13,34,57-59

See also Trail; Hardgrave; Thompson; Mormon; Bicknell; Hinchman; and Foreman formations.

Jurassic time, events in.................. 107

Jura Valley, description of................ 11

Juvavites erlichi......................... 31

K.

Keddie, Arthur, map of..................

Keddie Ridge, gravels of ................ 79 rocks on ................. 18, 19,24,82,84

Kettle meta-andesite, occurrence and char-

acter of...................... 84-85

relation of, to other rocks........... $85-86,87$

Kettle Roek, gravels near............... 70-71,94

Knowlton, F. II., fossils determined by ... 55, 75,77

L.

Laurus californica . . . . . . . . . . . . . . . . . . 75,77

grandis............................ 75

salicifolia........................... $\quad 75$

Lavas, alteration of.................... 81

See Metarhyolite; Meta-andesite.

Leda................................ 24

Leguminosites......................... 75

Lights Creek, gold on ................ 116-118 gravel on.......................... 66

rocks on $\ldots \ldots \ldots \ldots \ldots \ldots \ldots \ldots \ldots .54,85,90$

Lima cardiiformis...................... 47

dilleri............................ 46,47

recticostata........................ 40

rigidula............................ 47

sinuata............................ 40

taylorensis .................... 46, 47

tenuistriata........................ 47

sp.............................. 40,47

Lindgren, Waldeman, on ancient streams.... 64

on gravels......................... 72

on Milton formation................. 58

on Sailor Canyon beds................ 57

on Sierra Valley ...................... 78

on Truckee region................... 101

Little Grizzly Creek, gold in.............. 117 rocks on and near............... 26,30,88, 91

Little Long Valley, gravels in ............. 63

Loftusia ............................... $\quad 29$

columbiana ...................... 29

Lone Rock, gravels near.................. 70 rocks of ............................ 93

Lophophyllum profundum ................ 24

sp.............................. 27

Lost Chance Valley, rocks in ............ 93,94

\section{M.}

McClond River, fossils from ............... 28

Macrocephalites...................... 49

Magnolia californica .................. 75,77

Hilgardiana........................ 75 
Magnolia californica, Inglefieldi............. $\quad r$ rage lanceolata........................ 75,77

Map, geologic, of region...

Map, topographic and geologic, of Honey Lake quadrangle ............ Pocket. topographic and geologic, of Indian Valley quadrangle.............. Pocket.

Mapes, gravel near....................... 71

Marginifera............................. 28

Mariposa, rocks near

Mariposa formation, occurrence and character

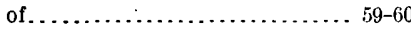

Meekella striaticostata.................... 27

sp.............................. 28

Meekopora sp..........................

Meta-andesite. See Taylor; Kettle; Reeve; Fant; and Hull meta-andesites

Metarhyolite, occurrence and character. of. ... 81-82 relation of, to other rocks............. 82

Milford, gravels near.................... 71

Milton formation, fossils of................ $\quad 59$ occurrence and character of............ 58-59

Milton region, drainage of.

Mineral springs, occurrence and character of .................... 119-120

Mines, list of $\ldots \ldots \ldots \ldots \ldots \ldots \ldots \ldots \ldots .112-114$

Mining, history of ....................... 111

Miocene igneous rocks, occurrence and character of . .................. 92-93

Miocene time, events in ................ 109-110

Modin formation, correlation of ............ 36

Modiola............................... 39,46

imbricata.......................... 46

subimbricata......................... 46

sp................................ 40,60

Mohawk Valley, gravels at............... 63 gravels northeast of. ................ 71-72

Mohawk Valley fault, description of...... 102-103

Monotis.............................. 57,58 subcircularis....................... 33

Monte de Oro formation, fossils of ......... 60 occurrence and character of............. 59

Montgomery Creek, rocks on......... 14-15, 16,89

Montgomery limestone, fossils and age of. . .. 16-17 occurrence and character of ............ 16 relation of, to other formations...... 15, 17,19 figure showing .................. 15

Montlivaultia........................... 40

Moonlight, gold near................. 110-118 gravels near.................... 66-67 iron ore near...................... $\quad 118$ rocks near...................... 85,89

Moraines, glacial, occurrence and character of. $\quad 80$

Mormon formation, fossils and age of . . ..... 4C-47 occurrence and character of............ 44-46 relation of, to other formations....... 43-44, $47-48,50,57,88,91$

figure showing................... 48

Mountain Meadows, description of. .......... 11,53 gold at.......................... 110-118 gravels of. ....................... 67-68 rocks of . . . . . . . . . . . .

Mount Ingalls, gravel on.............. 71 rock of . . . . . . . . . . . .

Mount Jura, gravels of. . .................. 61-62 rocks on.......... $37-39,42-46,49,51,87,88,91$
Mount Jura belt, structure of. ........... 97-98

Mount Jura syncline, structure of. . . . . . . . . . . 98-99

Myalina subquadrata................... 27 sp................................. 28

Myoconcha sp......................... $\quad 27$

Myrica Ungeri......................... $\quad 75$

Mytilus .............................. $\quad 39$

sublævis .......................... 47

sp............................. 40, 47

N.

Nanney, rocks near..................... 94

Nerinea............................. 44, 50

Nevada basin, rocks of. . . . . . . . . . . . . 58-59, 60

North Arm, pot hole on ................. $79-80$ rocks near...... $38,42,43,45,49,52,53-54,85,87$

\section{o.}

Opis.................................. $\quad 44$

paradoxa......................... 44

Oregon, southwest, fossils of ................ 77

Oreodaphne litsæformis................ 75

Ormoceras............................ 16

Oroville, rocks near.................... 59

Orthis................................ 16

flabellum.......................... 16

marshii........................... 46

michelini............................. 24

Orthotetes sp.......................... 28

Ostræa............................... $\quad 39$

bononiæ.......................... 50

bruntrutana......................... 52

sp............................. 40,60

Oxytoma.............................. 50

P. •

Paul, E. G., fossils collected by ............. 55

Peale diggings, gravels of................... 62

Peale formation, fossils and age of........... 24-25 occurrence and character of. ............ 24 relation of, to other rocks.... $25,29,57,84,88,91$

Pebbles, fracturing of..................... 21

fracturing of, figure showing.......... 21,22

Pecten acutiplicatus.................... 39,40 demissa-gingensis.................... 47

disciformis............................ 47

suprajurensis....................... 52 sp........................ 40, $47,56,60$

Pelecypoda............................ 24

Pencil structure, description of ............. 54-55

figure showing..................... 54

Perisphinctes....................... 47, 49,56

Persea Dilleri.......................... $\quad{ }_{75}$

pseudocarolinensis................... 75

Peters Creek, rocks on......... 26-27,30,54-55, 85

Phillipsia sp............................. $\quad 24$

Pholadomya fidicula...................... 47

sp........................... 40, 47

Phragmites œningensis.................. $\quad 75$

Pinna............................... $\quad 39$ cuneata........................... 47

cuneiformis......................... 47

expansa.......................... 39,40

Platanus appendiculata.................... 75

dissecta............................. 75

Plateau, description of ................. 10 
Page.

Pleuromya sp

Pleurotomaria sp.

Plioceno igneous rocks, acter of.

. 93-94

Pliocene time, events in.

109-110

Podozamites taylorvillensis sp.

Populus Zaddachi.

55

Prattville, rocks near

Productus punctatus. semireticulatus. sp.

Pseudomonotis

$$
\text { sp. }
$$

Jteroperna costatula

$$
\text { plana. }
$$

$\mathrm{sp}$

Pterophyllum.

Pterospermites spectabilis.

Pugnax sp.

Pyrrhotite, occurrence and character of.... 115,119

\section{Q.}

Quaternary deposits, occurrence and character of.

Quaternary lavas, occurrence and character of 95-97

Quaternary time, events in.............. 110-111

Quercus Boweniana.

convexa

distincta.

elænoides.

gigantissimus.

Moorii

Olarseni.

R.

Red Clover Creek, rocks on

Red Mountain, gravel of. rocks of.

Reeve meta-andesite, occurrence and character of.

relation of, to other rocks.

Reineckia figure showing...................

Relief, description of

Rhacophyllites sp.

\section{Rhombopora.}

Rhus metopioides mixta.

Rhynchonella... quadriplicata. sp.

Rhyolite, analysis of.

flow of.

occurrence and character of ............ $92-93$

Rhyyolite dikes, occurrence and character of. . 90-91

Robinson formation, fossils and age of . . . . 27-29 occurrence and character of............. 26-27 relation of, to other formations........ 25, $29-30,32,33-34,57,85,86$

figure showing .................. 29,48

Kound Valley Reservoir, gold near......... 1.18 rocks at. ....................... $89,90,91$

Rush Creek, gold on ................. 117
S.

Page.

Sabalites califomicus................... 75,77

Sagenopteris......................... 55

sp.................................. 55

Sailor Canyon formation, fossils of ......... 57-58

occurrence and character of............ 57

Salix californica........................ 75

Schizophoria.......................... 28

Schuchert, Charles, fossils determined by ... 24-25

Sedimentary rocks, description of ......... 13-80

Serpentine, occurrence and character of..... 88-89

Shoo Fly, rocks near.................. 92,97 spring near......................... 120

terraces near ....................... 80

Shoo Fly formation, fossils and age of....... $\quad 23$ occurrence and character of............. 23 relation of, to other formations...... 22, 23, 84

Shore gravel, occurrence and character of.... 74

Sierra City, gravels near.................. 63

Sierra Nevada, faults limiting, location of, map showing................ 8

geology of . ........................ $8-9$

Sierra Valley, drainage of................ $78-79$

Silurian rocks, occurrence and character of... 13 See also Grizzly formation.

Silurian time, events in................. 105

Smith, J. P., fossils determined by ....... 33,59 on Swearinger slate.................. 33

Soda Creek, gold on.................... 117

Sphæroceras gervilli.................... 47 sp ................................ 47

Sphenopteris Guyottii.................. 75

Spirifer cameratus.....................27,28 lineatus............................ 27

striatus............................ 24

sp........................... 27, 28

Spiriferina pulchra ..................... 28 sp........................... 27,31,32

Squamularia guadalupensis............... 27 lineata............................... 28

Squaw Creek, drainage by .............. 12

gravels on ......................... 71

rocks near.......................... 94

Stanton, T. W., fossils collected by ... 24, $36,56,60$ Stanton, T. W., and Curtice, Cooper, fossils collected by .................... 28

Stenopora sp........................ 22,25

Storrs, James, fossills collected by ......... 17, $22,25,27,55,56,60$

Stratification, description of............. 13-80 Streptorhynchus crenestria...............24,27

sp................................ 27

Striatopora sp......................... $\quad 27$

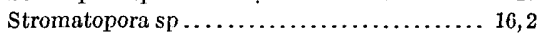

Structure, description of .............. 97-104

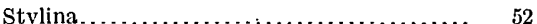

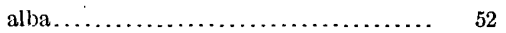

echinulata......................... 52

intermedia........................ 52

minuta........................... 52

subjecta............................ 52

tertia.............................. 52

tubulifera.......................... 52

Superior mine, description of ............... 116

Surprise Creek, rocks on ................. 54 
Susan Creek, drainage by rocks on.

Swearinger slate, fossils and age of occurrence and character of ........... 32-33 relation of, to other formations... . 30,33-34, 37

figure showing

Syringopora..................... 16, 17 serpens..................... 16

'T.

Taylor diggings, gravels of............. 61

Taylor meta-andesite, age of. ............. 84

occurrence and character of........... 82-84

relations of, to other formations....... 29,284

figure showing................ 29

Taylor rock, rocks near. . . . . . . . . . . 19, 83

Taylorsville, rocks near........ 17, 18,38,42,84,91

Taylorsville fault, description of......... 99-100

Taylorsville formation, fossils and age of ... 19 occurrence and character of . .......... 17-18 relation of, to other formations........ 15, $18-19,22,90,91$

figure showing.

Taylorsville region, columnar section of. .... 12 location of ....................... 7 descriptive geology of............ 8-9, 13-104 economic geology of................ 111-121 geologic history of . . . . . . . . . . . . . . 104-111 mining claims in, list of............ 112-114 map of. .................... 111 résumé of. . . . . . . . . . . . 120-121 section of, figure showing ............ 96 topography of $\ldots \ldots \ldots \ldots \ldots \ldots \ldots \ldots \ldots, 7-13$

'Ierebratula.................... 44, 46, 47 perovalis....................... 46

Tertiary gravels. See Auriferous gravels.

Thompson limestone, fossils and age of...... occurrence and character of........... 41-43 relation of, to other formations...... 41, $43-44,47-48,87$ 'Thompson Peak, rocks of and near . . . . . 70,95-96 Topogrảphy, description of . ......... 7-8,9-13 Tower Rock, rocks near. ............ 14, 15,88 Trail formation, correlation of . . . . . . . . . . 36-37 fossils of . . . . . . . . . . $36 \ldots \ldots \ldots \ldots \ldots . \ldots$ occurrence and character of.......... 35-36 relation of, to other formations......... 36, 7
Triassic rocks, occurrence and character of. $13,57-50$ Triassic time, events in. . . . . . . . . . . . 106-107

Trigonia................... $39,46,52,56$ clevellatæ..................... 50

formosa................. 47

glabræ........................ 50

hemispheria.................. 47

lusitanica..................... 50

naviformis.................. 50,56

navis...................... 40,50

obliqua.................... 49,50

plumasensis . . . . . . . . . . . . . . . 49,50

schapoidæ..................... 50

undulatæ...................... 50

sp....................... 40,47,60

- Tropites. . . . . . . . . . . . . . . . . . . . 31

Truckee region, faults in................ 101

Turner, H. W., fossils determined by...... 29.

on Cedar Creek gravels. . . . . . . . . . . . . $\quad 79$

on Haskell Peak rocks. . . . . . . . . . . . 63

on Juratrias . . ................. 57,58

on Mohawk Valley fault............. 102

Turritella uvasana.................... $\quad 77$

U.

Ulmus californica................... $75-77$

pseudofulva..................... 75

Ulrich, E. O., fossils determined by ..... 14, 17,25

Unio........................... 39

V.

Venericardia planicosta............... 77

Volcanic flows, occurrence and character of. . 74,81

Volcanism, occurrence of ............. 9

W.

Walcott, C. D., fossils determined by .... 16, 17,27

Wards Creek, rocks on.............. 27,86

White, David, fossils determined by......... 29

Willards Creek, rhyolitic tuff from, analysis of $\quad 92$

Willards Creek district, gravels of...... 68, 73-74

Wolf Creek, gold on ................... 117

$Y$.

Yoldic.

40-41, 85,90 Zaphrentis

16 